\title{
Mikrostruktúrált optikai szálak diszperziójának vizsgálata spektrális interferometriával
}

Ph.D. értekezés

Szerző:

Grósz Tímea

Témavezető:

Dr. Kovács Attila Pál

adjunktus

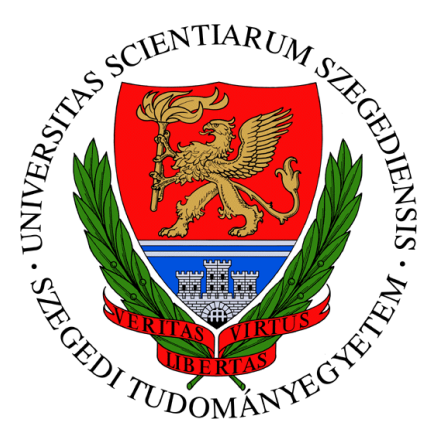

Fizika Doktori Iskola

Optikai és Kvantumelektronikai Tanszék

Szegedi Tudományegyetem Természettudományi és Informatikai Kar

Szeged 


\section{TARTALOMJEGYZÉK}

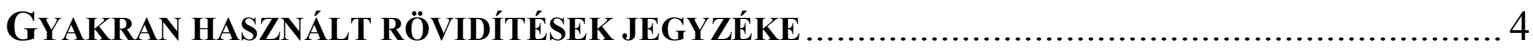

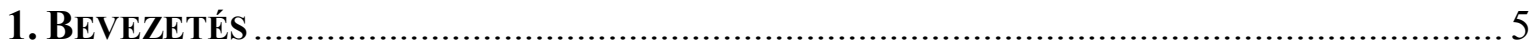

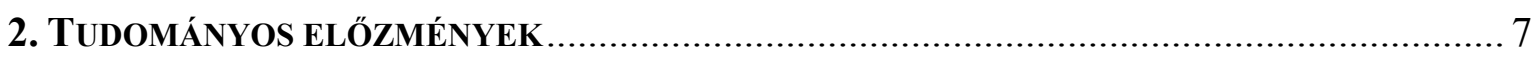

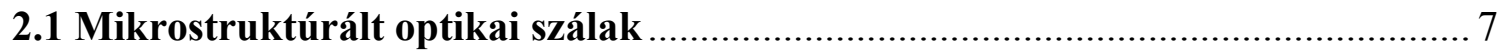

2.1.1 Mikrostruktúrált szálak vezetési mechanizmusai .......................................... 10

2.1.2 Hagyományos és mikrostruktúrált szálak diszperziós jellemzőinek

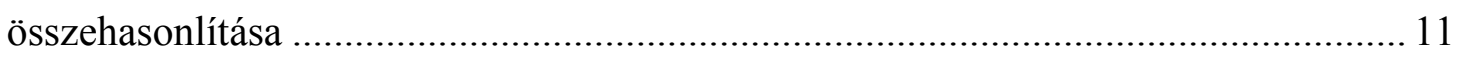

2.1.3 Optikai szálak lézerimpulzusok időbeli alakjára gyakorolt hatásának leírása .... 14

2.1.4 A dolgozatban vizsgált mikrostruktúrált szálak jellemzői ............................... 17

2.1.4.1 Bragg-típusú optikai szál .................................................................... 17

2.1.4.2 HC-800-02 fotonikus optikai szál.......................................................... 18

2.2 Impulzusok időbeli alakjának meghatározására szolgáló módszerek

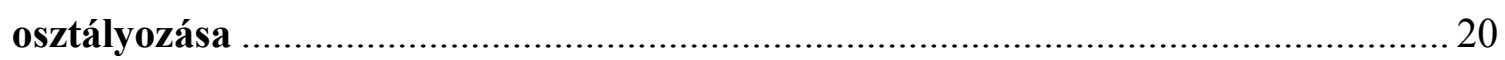

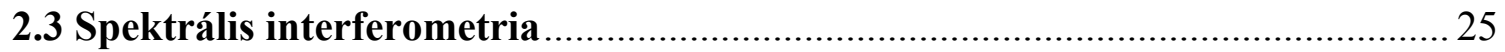

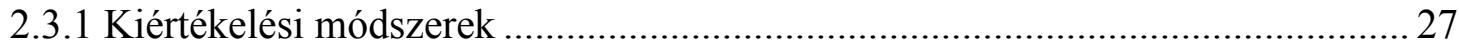

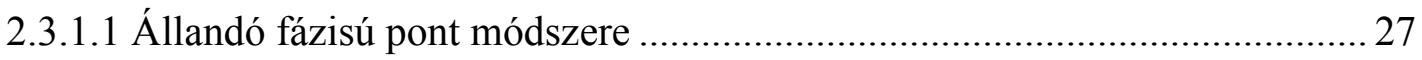

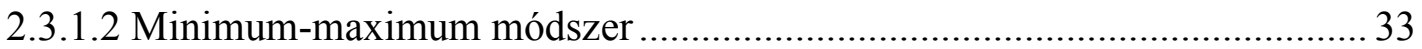

2.3.1.3 Fázismodulált harmonikus függvény illesztése ........................................... 34

2.3.1.4 Fourier-transzformációs módszer ......................................................... 35

2.3.1.5 Ablakolt Fourier-transzformációs módszer ............................................... 36

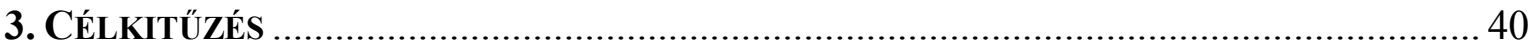

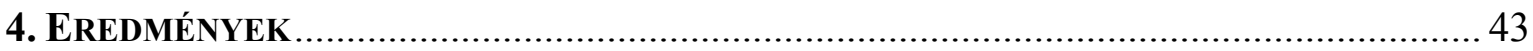

4.1 Az állandó fázisú pontok és a magasabb rendü diszperzió kapcsolatának

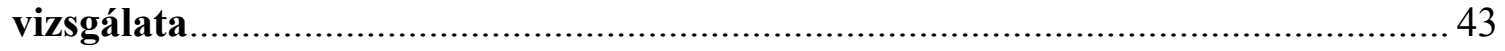

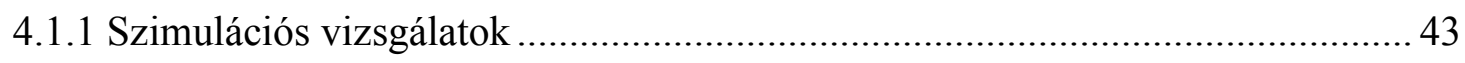

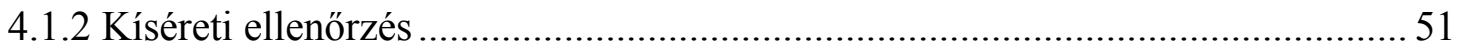

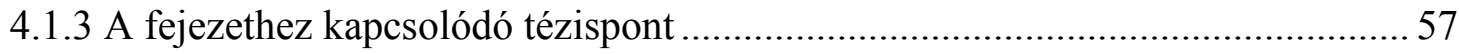


4.2 Spektrális interferogramok kiértékelési módszereinek összehasonlítása ........... 58

4.2.1 Kiértékelés állandó fázisú pont módszerének alkalmazásával..........................59

4.2.2 Kiértékelés a minimum-maximum módszer alkalmazásával ............................ 60

4.2.3 Kiértékelés fázismodulált koszinusz-függvény illesztésével ............................ 61

4.2.4 Kiértékelés Fourier-transzformációs módszerrel .............................................62 62

4.2.5 Kiértékelés az ablakolt Fourier-transzformációs módszerrel............................. 63

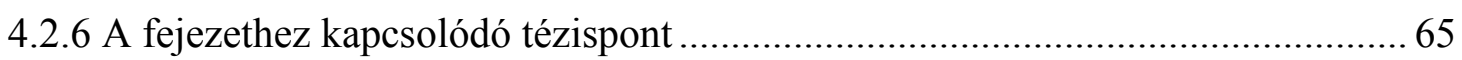

4.3 A HC-800-02 típusú fotonikus optikai szál polarizációfüggő diszperziójának

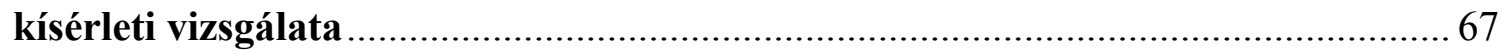

4.3.1 A polarizációfüggő kromatikus diszperzió kísérleti vizsgálata......................... 68

4.3.2 A kromatikus diszperzió és a fotonikus szál helyzete közötti kapcsolat kísérleti

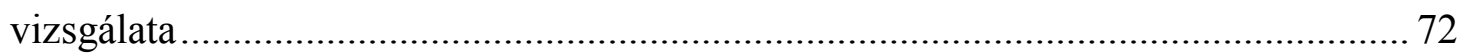

4.3.3 A kromatikus diszperzió és a fotonikus szál hossza közötti kapcsolat kísérleti

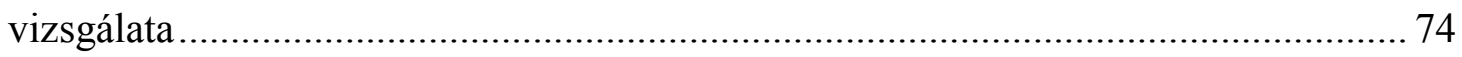

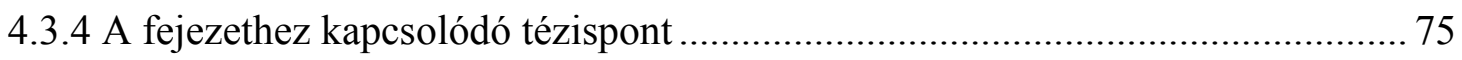

4.4 A HC-800-02 típusú fotonikus optikai szál polarizációs módusdiszperziójának

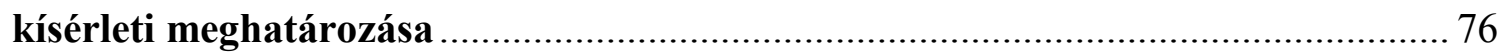

4.4.1 A csoportkésleltetés-különbség indirekt meghatározása................................... 76

4.4.2 A csoportkésleltetés-különbség direkt meghatározása...................................... 77

4.4.3 A fejezethez kapcsolódó tézispont .................................................................... 79

4.5 A kromatikus diszperzió meghatározása időben átfedő módusok esetén az ablakolt Fourier-transzformációs gerincvonal kereső algoritmus segítségével ....... 81

4.5.1 Polarizációfüggő diszperzió kísérleti vizsgálata .............................................. 81

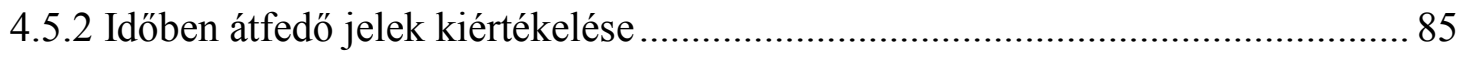

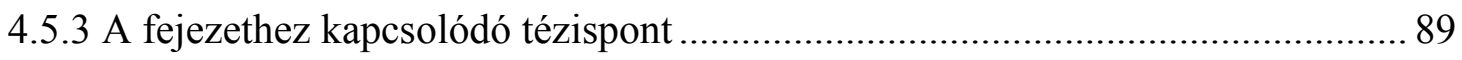

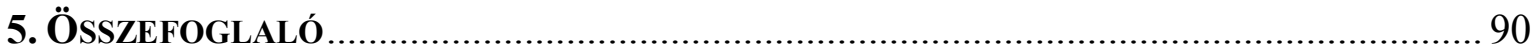

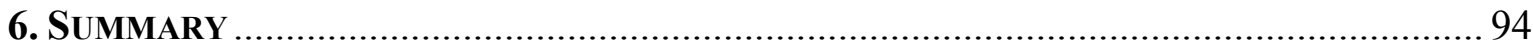

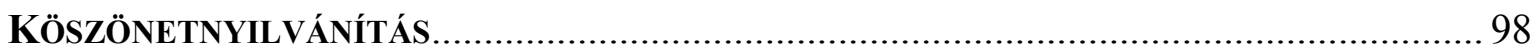

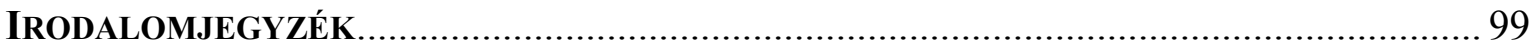




\section{GYAKRAN HASZNÁLT RÖVIDÍTÉSEK JEGYZÉKE}

CFF - cosine function fit, koszinusz-függvény illesztés

$D G D$ - differential group delay, csoportkésleltetés-különbség

FOD - fourth order dispersion, negyedrendü diszperzió

FT - Fourier-transform, Fourier-transzformáció

FWHM - full width at half-maximum, félértékszélesség

$G D$ - group delay, csoportkésleltetés

$G D D$ - group delay dispersion, csoportkésleltetés-diszperzió

HC-PCF - hollow-core photonic crystal fiber, légmagos fotonikus optikai szál

$M M$ - minima-maxima, minimum-maximum

$P B G$ - photonic band gap, fotonikus tiltott sáv

PCF - photonic crystal fiber, fotonikus optikai szál

$P M D$ - polarization mode dispersion, polarizációs módusdiszperzió

$Q O D$ - fifth order dispersion, ötödrendü diszperzió

$S O D$ - sixth order dispersion, hatodrendü diszperzió

$S P P$ - stationary phase point, állandó fázisú pont

SRI - spectrally resolved interferometry, spektrálisan bontott interferometria

Ti:S - titanium-sapphire, titán-zafír

TOD - third order dispersion, haramdrendü diszperzió

WFF - windowed Fourier-filtering, ablakolt Fourier-szürés

WFR - windowed Fourier-ridges, ablakolt Fourier-transzformáción alapuló gerincvonal kereső algoritmus

WFT - windowed Fourier-transform, ablakolt Fourier-transzformáció 


\section{BEVEZETÉS}

Napjainkban az optikai szálak alkalmazása igen széleskörü, nem csupán a telekommunikációban, hanem az orvostudományban, a kutatásban, lézerimpulzusok mobilis továbbításában, valamint korszerű szenzorikai megoldásokban is jelentős szerepük van. Éppen ezért a fejlesztések valamint a hagyományos optikai szálak alkalmazhatóságának határait kiterjesztő alternatív megoldások iránti igény folyamatosan növekszik. Elrugaszkodva a korábban ismert klasszikus száloptikai megoldásoktól, a kilencvenes években az ún. fotonikus optikai szálak (photonic crystal fiber, PCF) [1-14] és Bragg-típusú szálak [15-18] megjelenése új távlatokat nyitott a fotonikában. Ezen mikrostruktúrált szálak legfontosabb tulajdonsága, hogy igen sok alkalmazás által támasztott követelménynek eleget tudnak tenni, hiszen optikai tulajdonságaik, mint például diszperziójuk, kettőstörésük, nemlinearitásuk, valamint a vezetési tulajdonságaik megfelelő tervezéssel tetszés szerint alakíthatók, akár egymástól függetlenül is [14]. Lehetőség van olyan geometriák tervezésére, melyekkel gyakorlatilag diszperziómentes vezetés is megvalósítható [1,3,4,9-11,13]. A levegőben, azaz légmagos szálban (hollow-core photonic crystal fiber, HC-PCF) történő fényvezetés lehetősége [19-22] különösen jelentős, hiszen ezáltal nagy teljesítmények átvitele valósítható meg alacsony veszteségek és csökkentett nemlinearitás mellett. Kedvező tulajdonságaik miatt a légmagos szálakat gyakran alkalmazzák száloptikai giroszkópok gyártásában, gáz spektroszkópiában, nagyteljesítményü ultrarövid optikai impulzusok átvitelében és kompresszálásában, endoszkópiában, optikai kommunikációs rendszerekben, valamint különböző szenzorokként is [19-26].

Habár az optikai szálak gyártása jelentős fejlődésen esett át az elmúlt évtizedekben, az, hogy a legyártott szál pontosan ugyanolyan struktúrával rendelkezzen, mint ahogyan azt megtervezték, és ezáltal a modellezés alkalmával meghatározott optikai tulajdonságokkal bírjon, viszonylag nehezen kivitelezhető, még egyszerübb geometriával rendelkező optikai szálak esetén is [27]. Ahhoz, hogy a gyártási technológia hatásait már a tervezésnél is figyelembe tudják venni, illetve azért, hogy minél kevesebb lépésben sikerüljön a célparaméterekkel rendelkező szálat létrehozni, és egyúttal az igen költséges tervezési-gyártási folyamatot hatékonyabbá tenni, nagyon pontos mérési módszerre van szükség. 
Optikai elemek spektrális fázisának meghatározására gyakran alkalmazott nagypontosságú, lineáris módszer a spektrálisan bontott interferometria [28,29], mely optikai szálak diszperziómérésében is bizonyított már [30,31]. Előnye, hogy mivel lineáris módszer, emiatt aránylag olcsó, nem igényel hosszú szálmintát, valamint, hogy magasabb rendü diszperziók mérésére is nagypontossággal alkalmazható [29], mely a mikrostruktúrált szálak gyakori tulajdonsága.

Munkám során különböző spektrális interferometrián alapuló kiértékelési eljárások alkalmazhatóságát vizsgálom meg Bragg-típusú, valamint légmagos fotonikus optikai szálak diszperziójának meghatározására. A dolgozat első részében ismertetem a mikrostruktúrált szálak müködési mechanizmusait és diszperziós tulajdonságait, majd az alkalmazott öt, spektrális interferometrián alapuló kiértékelési módszert mutatom be. Az értekezés részletes célkitüzéseinek ismertetése után bemutatom szimulációk és mérések alapján, hogy mely kiértékelési eljárás bizonyult a legpontosabbnak, illetve, hogy egy-egy módszernek milyen előnyei és hátrányai lehetnek adott típusú optikai szálak diszperziójának meghatározásakor.

A dolgozatban ismertetett kísérleteket az SZTE Optikai és Kvantumelektronikai Tanszékén működő TeWaTi és hELIos lézerlaboratóriumokban végeztem. 


\section{TUDOMÁNYOS ELÖZMÉNYEK}

\subsection{Mikrostruktúrált optikai szálak}

A fotonikus optikai szálak keresztmetszete jelentősen eltér a hagyományos optikai szálak klasszikus felépítésétől, melyek legegyszerübb esetben egy tömör magból, és az ezt körülvevő köpenyből állnak (2.1 ábra). A köpeny (cladding) $n_{2}$ törésmutatója kisebb, mint a mag (core) $n_{1}$ törésmutatója, így a fényvezetés a teljes visszaverődés elvén valósul meg.

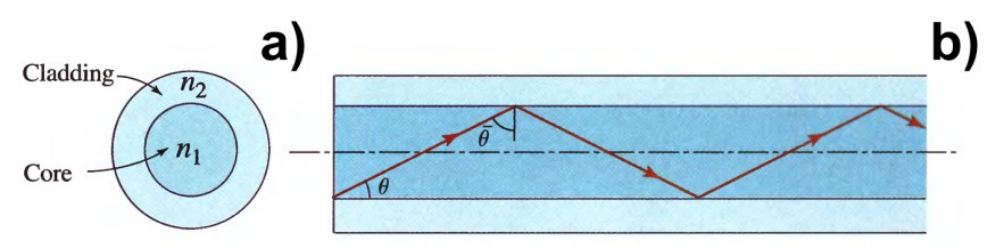

2.1 ábra Hagyományos optikai szálak felépítése (a) keresztmetszeti és (b) hosszanti nézetből [32].

A fotonikus szálakat gyakran nevezik lyukacsos szálaknak is, hiszen a szál teljes hosszában mikroszkopikus, levegővel teli csatornák futnak végig egymással párhuzamosan. A csatornák általában azonos átmérőjủek, de attól függően, hogy milyen tulajdonságok kialakítása a cél, különböző szálgeometriák tervezhetők, melyek közül néhány a 2.2 ábrán látható. A fekete szín a csatornákat, a fehér a tiszta, a szürke pedig az adalékolt üveget jelenti. Anyagukat tekintve leggyakrabban tiszta kvarcból készülnek, bár az utóbbi időben már polimereket és más típusú üvegeket is használnak. Aszerint, hogy a mag szerepét egy üres vagy pedig tömör cső tölti be, kétféle száltípust különböztethetünk meg. A legelső törekvések az első típusba tartozó ún. hollow-core, azaz légmagos szálak megvalósításának irányában történtek, mégis az első müködő fotonikus szál a tömör magú változat volt [33].

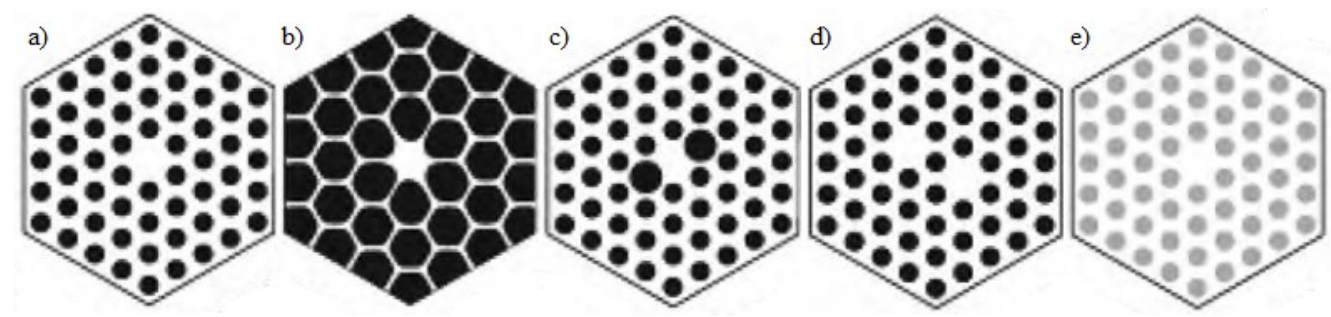

2.2 ábra Fotonikus optikai szálak különböző szerkezeti megvalósításai: (a) végtelenített egymódusú, (b) nagy nemlinearitású, (c) kettőstörő, (d) kétmagú és (e) adalékolt üveg felhasználásával készült szál [33]. 
A tömör magú szálaknál a csatornák alkotta tipikusan szabályos rács közepéböl hiányzik egy csatorna, helyette egy a köpenyhez viszonyított nagyobb törésmutatójú anyag, általában valamilyen üveg van. A tömör magú szálak fényvezetése már nem a klasszikus optikai szálaknál megszokott teljes visszaverődés elvén alapszik, hanem az ún. effektív-index vezetésen, ritkább esetben pedig a fotonikus tiltott sáv (photonic band gap, PBG) vezetésen $[8,10,16]$, melyekről bővebb leírás a 2.1.1 fejezetben olvasható. A szálak geometriájának megfelelő kialakításával elérhető, hogy csak egyetlen módus vezetése valósuljon meg, így a módusdiszperzió (ld. 2.1.2 fejezet) okozta impulzuskiszélesedés elkerülhetővé válik. Ehhez a csatornák átmérőjét a köztük lévő távolsághoz képest kisebbre kell tervezni. Kísérletileg bizonyították, hogy az így kialakított szálak igen széles, 4571550 nm-es hullámhossztartományban egymódusú fényvezetőként müködnek [1]. Elméletileg ez kisebb hullámhosszakra is teljesül, azaz az ehhez hasonló szálak joggal nevezhetők ún. végtelenített (határhullámhossz nélküli) egymódusú fényvezetőknek. Fontos kiemelni, hogy a hagyományos szálakkal ellentétben az egymódusú vezetés fenntartásához ez esetben nem szükséges kis magátmérő, ami nagyobb teljesítmények átvitelét teszi lehetővé. Ha azonban a csatornák átmérőjét a magátmérőhöz képest kisebbre tervezik, vagyis a móduskeresztmetszet lecsökken, akkor a diszperzió a vártnál kisebb, akár a látható tartományba eső hullámhosszakra is elhanyagolhatóan kicsi lehet. Ilyen típusú szálak megfelelően nagy intenzitás mellett szuperkontinuum generálásra is alkalmasak lehetnek megnövekedett nemlinearitásuk miatt [32].

A légmagos szálak esetén a fényvezetés voltaképpen egy levegővel teli csatornában történik, így ezen száltípus diszperziója és nemlinearitása is igen csekély. Ezen szálak a PBG vezetés elvén müködnek. Tekintve, hogy ilyen paraméterek mellett az átvihető teljesítmény sokkal nagyobb, mint például tömör magban, a légmagos szálak szállézerrendszerekben és gázanalizátorokban is igen fontos alkalmazásra találtak [32]. Az évek során különböző légmagos PCF geometriákat terveztek és vizsgáltak meg különböző szempontok alapján. A HC-800 típusú optikai szálak [26] az utóbbi években a figyelem középpontjába kerültek. Segítségükkel szinte teljesen torzulásmentesen sikerült megvalósítani igen komplex polarizációs állapottal rendelkező, nagyintenzitású ultrarövid impulzusok átvitelét is, ami sok alkalmazás szempontjából érdekes lehet [22,24], így több kutatócsoport is vizsgálni kezdte őket. Weise és munkatársai tanulmányukban bizonyos mechanikai torzító hatások nemlinearitásra, magasabb rendü diszperzióra és kettőstörésre gyakorolt hatását vizsgálták meg analitikusan és mérések segítségével egy $110 \mathrm{~cm}$ 
hosszúságú HC-800-01 PCF esetében [34]. Egy másik csoport a HC-800-01-es szál módusszerkezetének vizsgálatakor megállapította, hogy az 1 méternél rövidebb szálak esetében magasabb rendủ módusok gerjesztődhetnek, habár a szálat eredetileg egymódusú vezetésre tervezték [21]. A szálban lévő levegő-kvarc aránynak és egyéb geometriai paramétereknek, mint például a csatornák közötti távolságnak, a tiltott sáv kialakulására gyakorolt hatását numerikus módszerek segítségével szintén vizsgálták a fent említett száltípusnál [35]. A HC-800-01 típusú száltól geometriáját és optikai paramétereit tekintve csupán kissé különbözik a HC-800-02 típusú fotonikus szál. Ezen utóbbi szál bizonyos tulajdonságait, úgy mint a tiltott sáv kialakulása vagy a kettőstörés, illetve ezek érzékenységét megnyúlásra és hidrosztatikai nyomásváltozásra Statkiewicz és munkatársai ugyan már megvizsgálták [36], azonban a működési hullámhossztartományához képest csupán igen szűk, 800-860 nm-es tartományban.

Az ún. Bragg-típusú szálak [15-18] valamilyen értelemben a légmagos szálak elődeinek tekinthetők, hiszen a fényvezetés e szálak esetében is egy, a köpenyhez képest kisebb törésmutatójú magban valósul meg, mely lehet üres vagy pedig tömör üveg is [37,38]. Ehhez olyan köpenystruktúrára van szükség, melyben a magot egymást követö kisebb és nagyobb törésmutatójú rétegek veszik körül (2.3 ábra). A világos szürkével jelölt rétegek azonos, kisebb törésmutatójú rétegeket jelentenek, míg a sötétszürkével jelölt rétegek szintén egymással azonos, de nagyobb törésmutatóval rendelkeznek.

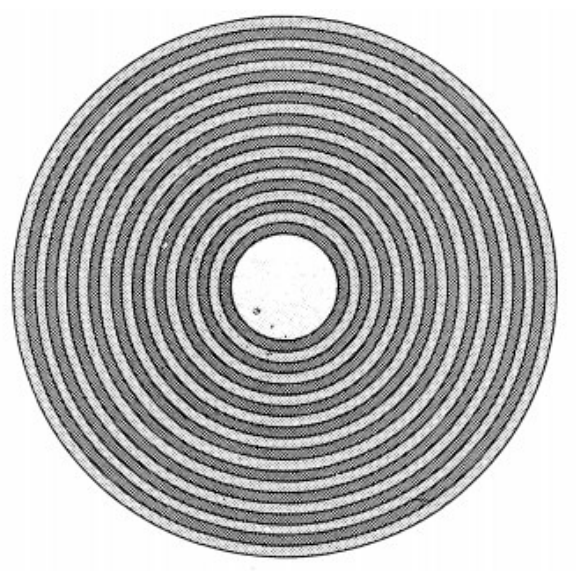

2.3 ábra Bragg-típusú optikai szál [15].

Elektromágneses hullámok alacsony törésmutatójú közegben vagy légmagú szálakban történő vezetése különösen jelentős ultraibolya és lágy röntgen hullámhossztartományba eső jelek továbbításakor, ugyanis ezen frekvenciákon már szinte 
az összes anyag nagy veszteséget okoz. Megfelelő tervezéssel módus- és hullámhosszszürés, valamint egymódusú vezetés megvalósítása is lehetséges ebben az esetben. Az egymódusú vezetés feltétele, hogy a rétegek vastagsága sokkal nagyobb legyen, mint a vezetni kívánt hullámhossz [15].

\subsubsection{Mikrostruktúrált szálak vezetési mechanizmusai}

Mikrostruktúrált optikai szálak esetében kétféle vezetési mechanizmusról beszélhetünk, az ún. effektív-index vagy a PBG elvén alapuló vezetésröl [3,32]. A tömör magú fotonikus szálak esetén a fényvezetés a köpenyhez viszonyítva általában egy nagyobb törésmutatójú magban, legtöbb esetben a hagyományos optikai szálaknál megismert teljes visszaverődéshez igen hasonló módon, az ún. effektív-index vezetés elvén történik. Ha a csatornák átmérője az alkalmazott fény hullámhosszánál sokkal kisebb, akkor a mikrostruktúrált köpeny a szál anyaga és a szálban lévő levegővel teli csatornák által együttesen meghatározott effektív törésmutatójú, homogén közegként viselkedik. Ekkor a csatornák szerepe voltaképpen csak annyi, hogy a köpeny törésmutatóját a mag törésmutatójához képest lecsökkentsék. Ahogy azt az előző fejezetben láthattuk, ilyen geometriával leginkább az egymódusú szálak esetében találkozhatunk. Ha a csatornák átmérője és az alkalmazott fény hullámhossza összemérhető, akkor a köpeny kétdimenziós periodikus rendszerként kezelendő, így törésmutatója hullámhosszfüggő lesz. Ilyen geometriával rendelkező szálak effektív törésmutatója egy olyan átlagos törésmutatóval egyezik meg, mely súlyozva van a közegben jelenlévő intenzitáseloszlással, ezáltal pedig nagymértékben függ a hullámhossztól és a csatornák átmérőjétől, valamint távolságától. E szálak esetében a hullámvezető diszperziónak (ld. 2.1.2 fejezet) igen jelentős szerepe lesz. Fontos kiemelni, hogy a légmagos szálak azonban nem a fent ismertetett vezetési elveken müködnek.

A PBG vezetés, mely voltaképpen a periodikus struktúráról, fotonikus szálak esetén a levegő- vagy kis törésmutatójú csatornák faláról, Bragg-típusú szálak esetén pedig váltakozó törésmutatójú rétegekről történő koherens Bragg visszaszóródás eredménye [5,15], mind tömör, mind pedig légmagos szálak esetében megfigyelhetö. Azon tömör magú szálak esetén azonban, melyek magja a közeghez képest nagyobb törésmutatóval rendelkezik, az alapmódus vezetése mindig a teljes visszaverődés elvén valósul meg. Ekkor a PBG vezetés feltételei esetleg a magasabb rendű módusokra teljesülhetnek [3]. 
Azon fotonikus szálakat, melyek kizárólagosan a PBG vezetés elvén müködnek, és csupán bizonyos hullámhosszsávba eső fény számára átjárhatók, gyakran PBG szálnak is nevezik.

\subsubsection{Hagyományos és mikrostruktúrált szálak diszperziós jellemzőinek} összehasonlítása

Ahogy egy ultrarövid lézerimpulzus áthalad valamely diszperzív közegen, esetünkben optikai szálon, az időbeli alakja megváltozik, tipikusan megnyúlik, illetve egyéb más alakváltozás is felléphet. Hagyományos szálak esetén ötféle diszperziós jelenség léphet fel [32]:

- anyagi diszperzió,

- hullámvezető diszperzió,

- módusdiszperzió,

- polarizációs módusdiszperzió,

- nemlineáris diszperzió.

Az anyagi diszperzió az optikai szál anyagának hullámhosszfüggő törésmutatója miatt lép fel. Következménye, hogy a szálon áthaladó lézerimpulzus egyes spektrális komponensei különböző sebességgel terjednek, emiatt pedig az impulzus időben megnyúlik. Hagyományos optikai szálak esetében az anyagi diszperzió a látható és a közeli infravörös hullámhossztartományban a mag anyagára jellemző sima függvény. Némely mikrostruktúrált szál spektrumában viszont e hullámhossztartományokban abszorpciós völgyek alakulnak ki, melyek fázisugrások megjelenéséhez vezetnek a szál spektrális fázisfüggvényében [16]. Emiatt a diszperzió jellemzésére gyakran használt Taylorsorfejtésből adódó együtthatók meghatározásakor, valamint azon kiértékelési módszerek használatakor, amelyek arra a feltételezésre építenek, hogy a spektrális fázisfüggvény alacsony fokszámú polinommal közelíthető, mikrostruktúrált szálak esetében körültekintően kell eljárnunk.

A hullámvezető diszperzió az egyes gerjesztett módusok anyagi diszperzió okozta hullámhosszfüggő terjedési sebességét módosíthatja. E diszperzió megjelenése azzal magyarázható, hogy a magátmérő és a továbbított jel hullámhosszának arányától függően az impulzus nem csak a magban, hanem a szál köpenyében is terjedhet, így az ezekben jelenlévő optikai teljesítmények aránya is hullámhosszfüggővé válik. Tekintve, hogy a 
magban és a köpenyben eltérő a fázissebesség, az adott módus terjedési sebessége is megváltozik. A hullámvezető diszperzió az egymódusú szálak esetén is fellép. Akkor válik jelentőssé, amikor a használt hullámhossztartományban az anyagi diszperzió elhanyagolható, ugyanis egyébként egymás hatását kompenzálni tudják. Mivel az anyagi és a hullámvezető diszperzió egymástól függetlenül nem mérhető, így ezek együttes hatását kromatikus diszperziónak nevezték el.

A módusdiszperzió a multimódusú szálak jellemzője [3], ami a különböző transzverzális módusok eltérő terjedési sebessége miatt alakul ki. Tekintve, hogy a folytonosan változó törésmutatóprofillal rendelkező optikai szálak esetében a terjedési sebességek kiegyenlítettek, ezek módusdiszperziója kevésbé jelentős, mint például a lépcsős profilú szálaké. Mindkét száltípusra igaz azonban, hogy a módusdiszperzió okozta időbeli megnyúlás a szál hosszával arányosan nő egy kritikus hosszúságig, amelyet átlépve a módusok közötti csatolódások felerősödése miatt viszont lecsökken. Az időbeli megnyúlást rendszerint $\mathrm{ns} / \sqrt{\mathrm{km}}$ egységben adják meg. A módusdiszperzió kialakulása nagyban függ a szálbacsatolás módjától és pontosságától.

A polarizációs módusdiszperzió (polarization mode dispersion, PMD) egy sztochasztikus valószínüségi folyamat következménye. Megjelenése az optikai szálak gyártási hibáihoz és egyéb környezeti hatásokhoz köthető. Tekintve, hogy az optikai szálak magja általában nem tökéletesen körszimmetrikus és anyaga sem feltétlenül teljesen izotrop, előfordul, hogy még a nominálisan egymódusú optikai szálakban is gerjesztődnek egymásra merőleges polarizációval rendelkező módusok, azaz kettőstörő hatást mutatnak. Emiatt, ha a becsatolt fény polarizációs iránya nem esik egybe a szál egyik (gyors vagy lassú) tengelyének irányával sem, akkor két ortogonális polarizációs módus gerjesztődik, majd terjed a szálban. Ezek terjedési sebessége eltérő lesz, így a két módus között időkésés alakul ki. A PMD jellemzésére ezen időbeli késleltetést leíró, ún. csoportkésleltetéskülönbséget (differential group delay, $D G D$ ) szokás használni, ps/m egységben kifejezve. A PMD egymódusú szálak esetén is jelentőssé válhat, főképp, ha a kromatikus diszperzió elhanyagolható [32].

A nemlineáris diszperzió a mag törésmutatójának az intenzitásfüggése miatt lép fel, azonban csupán nagy fényintenzitások esetén jelentős. Az anyag nemlineáris viselkedése önfázis-modulációt eredményez, mely bizonyos körülmények között kompenzálni tudja az anyagi diszperzió impulzusra gyakorolt torzító hatásait is. 
Látható, hogy a fotonikus szálak diszperziós tulajdonságai jelentősen függnek a geometriájuk kialakításától. Ha a köpenyben lévő levegőcsatornák átmérője kicsi, akkor ezek hatása a diszperzió szempontjából elenyésző, a fényvezetési tulajdonságokat leginkább az anyagi diszperzió határozza meg. Ha a csatornák nagyobb átmérőjüek, akkor leginkább a hullámvezető diszperzió lesz domináns [3]. Kis móduskeresztmetszetü fotonikus szálak esetén a hullámvezető diszperzió különösen jelentős hatással bír [39], ám emellett a nemlineáris diszperzió is igen meghatározó. Ezek mellett kettőstörő fotonikus szálak esetén a polarizációs módusdiszperzió, multimódusú szálak esetén pedig a módusdiszperzió hatásaival is számolnunk kell.

Tekintve, hogy a különböző szálgeometriákhoz eltérő optikai tulajdonságok rendelhetők, további geometriák tervezése újabb és újabb alkalmazások lehetőségével kecsegtet. A szálak alkalmazhatóságát főként a szálban terjedő, illetve a szálból kijövő optikai impulzus diszperziója és a polarizációja [40-43] befolyásolja. Mivel sok alkalmazás kapcsolódik a kis és a nagy kettőstörés jelenségéhez is, az évek során különböző polarizációt kontrolláló megoldások születtek [23,40,41]. Továbbá számos elméleti [12,23,35,43-46] és kísérleti munka [2,6-8,20,47] mutatja, hogy akár minimális, a szál struktúráját érintő változások, mint például hosszanti vagy keresztmetszeti egyenlőtlenségek (főként a mag körüli régióban) is szignifikáns eltéréseket eredményezhetnek az optikai tulajdonságokban. A körszimmetriától való legkisebb eltérések is kettőstörő viselkedéshez vezethetnek, ami miatt az alapmódus két ortogonális polarizációs módusra bomlik fel [20,36,41,42] és PMD jelensége lép fel [6], ami bizonyos alkalmazások esetén probléma lehet [40]. Ugyan a szálhúzási technikák igen jelentős fejlődésen mentek keresztül és egyre pontosabbak lettek, a legyártott optikai szál struktúrája a legtöbb esetben kissé eltér a modellezés alkalmával megtervezettől. Ismeretes, hogy sokkal egyszerűbb geometriával bíró szálak esetén is jelentős figyelmet szentelnek a gyártott szál szerkezetében előforduló egyenetlenségek és azok optikai tulajdonságokra gyakorolt hatásainak vizsgálatára még napjainkban is [27], így könnyen belátható, hogy a mikrostruktúrált szálak vizsgálata fontos kutatási terület.

A gyártási technikák pontatlanságainak diagnosztizálására különböző megoldásokat dolgoztak ki az évek során. Az elkészült szálak struktúrája megvizsgálható például elektronmikroszkóp segítségével, majd a kapott paraméterek felhasználásával modellezéssel könnyedén megállapítható, hogy a szál optikai tulajdonságai milyen 
mértékben térnek majd el a tervezett, ideális struktúra mellett várható viselkedéstől [8,46,48,49]. Habár a kapott adatok visszacsatolásként szolgálnak és segítségükkel a gyártási folyamat tovább tökéletesíthető, a pontos szálkeresztmetszet rekonstruálása igen nehézkes, és gyakran bizonyos közelítésekkel és egyszerüsítések segítségével történik [2,41,45]. Egy másik megoldás lehet a szálgeometria gyártás közbeni monitorozása, melyhez egy gyors, precíz és nagyfeloldású képalkotó eljárásra van szükség. A Dopplereffektuson alapuló tomográfiai eljárás egy valósidejü, nem destruktív eljárás, melynek segítségével üvegmagú, aránylag kevés csatornát tartalmazó, fotonikus kristályszálak belső szerkezetét sikerült $100 \mathrm{~nm}$-es felbontással megadni [50]. Egyelöre azonban kérdéses, hogy e technika vajon alkalmazható-e olyan szálak esetén, melyek nagyszámú csatornát tartalmaznak avagy légmagosak.

Gyakran csak több lépésben sikerül az eredetileg megtervezett tulajdonságokkal rendelkező szálat előállítani, a mérések tehát lehetővé teszik a gyártási technológia hatásának a figyelembevételét a tervezésnél. Ahhoz, hogy minél kevesebb lépésben sikerüljön a célparaméterekkel rendelkező szálat létrehozni, és ezáltal az igen költséges tervezési-gyártási folyamatot hatékonyabbá tenni, természetesen nagyon pontos mérési módszerre van szükség, ami lehetőség szerint független a pontos szálkeresztmetszet ismeretétől.

\subsubsection{Optikai szálak lézerimpulzusok időbeli alakjára gyakorolt hatásának} leírása

Ismeretes, hogy az ultrarövid lézerimpulzusok felírhatók különböző frekvenciájú monokromatikus hullámcsomagok összegeként. Ekkor a közegbe lépő fényimpulzus térerősségének időbeli alakja a komponensek szuperpozíciójaként írható fel [51]:

$$
E_{b e}(t)=\frac{1}{2 \pi} \int_{-\infty}^{\infty} E_{0}(\omega) e^{i\left(\omega t-\varphi_{b e}(\omega)\right)} d \omega
$$

ahol $E_{0}(\omega)$ a spektrális amplitúdó, $\varphi_{b e}(\omega)$ a bejövő impulzus spektrális fázisa.

Amikor egy ultrarövid impulzus valamilyen diszperzív közegen halad keresztül, a különböző spektrális komponensek eltérő sebességgel haladnak, így az impulzus időbeli alakja megváltozik. Homogén és lineáris közeget feltételezve az áthaladás alkalmával 
fellépö hatásokat leírhatjuk oly módon, hogy az amplitúdóban bekövetkező változást az $A(\omega)$ amplitúdóátvitellel való szorzással, míg a fázistolást a $\varphi_{m}(\omega)$ spektrális fázisfüggvénnyel fejezzük ki:

$$
E_{k i}(t)=\frac{1}{2 \pi} \int_{-\infty}^{\infty} A(\omega) E_{0}(\omega) e^{i\left(\omega t-\varphi_{b e}(\omega)-\varphi_{m}(\omega)\right)} d \omega
$$

Ha a spektrális komponensek amplitúdójában bekövetkező változások elhanyagolhatók (azaz nincs abszorpció), az időbeli alakban bekövetkező változások csupán az optikai elem spektrális fázisától függnek. A spektrális fázisfüggvény karakterizálása az irodalomban szokásos módon általában az impulzus központi frekvenciája $\left(\omega_{0}\right)$ körül vett Taylor-sor együtthatóival történik

$$
\varphi_{m}(\omega) \approx \varphi_{m}\left(\omega_{0}\right)+\left.\sum_{n=1}^{N} \frac{1}{n !} \frac{d^{n} \varphi_{m}}{d \omega^{n}}\right|_{\omega=\omega_{0}}\left(\omega-\omega_{0}\right)^{n},
$$

ahol

$$
\begin{gathered}
\left.\frac{d \varphi_{m}}{d \omega}\right|_{\omega=\omega_{0}}=G D_{m}\left(\omega_{0}\right),\left.\quad \frac{d^{2} \varphi_{m}}{d \omega^{2}}\right|_{\omega=\omega_{0}}=G D D_{m}\left(\omega_{0}\right),\left.\quad \frac{d^{3} \varphi_{m}}{d \omega^{3}}\right|_{\omega=\omega_{0}}=T O D_{m}\left(\omega_{0}\right), \\
\left.\frac{d^{4} \varphi_{m}}{d \omega^{4}}\right|_{\omega=\omega_{0}}=F O D_{m}\left(\omega_{0}\right),\left.\quad \frac{d^{5} \varphi_{m}}{d \omega^{5}}\right|_{\omega=\omega_{0}}=Q O D_{m}\left(\omega_{0}\right),\left.\quad \frac{d^{6} \varphi_{m}}{d \omega^{6}}\right|_{\omega=\omega_{0}}=S O D_{m}\left(\omega_{0}\right) .
\end{gathered}
$$

A deriváltak rendre a minta csoportkésleltetését (group delay, $G D_{m}\left(\omega_{0}\right)$ ), csoportkésleltetés-diszperzióját (group delay dispersion, $G D D_{m}\left(\omega_{0}\right)$ ), harmadrendủ (third order dispersion, $\operatorname{TOD}_{m}\left(\omega_{0}\right)$ ), valamint negyedrendü (fourth order dispersion, $F O D_{m}\left(\omega_{0}\right)$ ) diszperzióját írják le az $\omega_{0}$ központi frekvencián. Amíg hagyományos üvegek esetén tipikusan csak harmad-, esetleg negyedrendig szokás vizsgálni a diszperziót, speciális optikai szálak [11,52] esetén, illetve lézerrendszerek diszperziójának optimalizálása közben a magasabb rendek, az ötödrendü (fifth order dispersion, $Q O D_{m}\left(\omega_{0}\right)$ ), illetve hatodrendü diszperzió (sixth order dispersion, $S O D_{m}\left(\omega_{0}\right)$ ) meghatározása is nagy jelentőséggel bír. Tekintve, hogy bizonyos impulzustorzulások könnyen hozzárendelhetők adott diszperziós koefficiens dominanciájához, gyakran nem csak a vizsgált minta spektrális fázisát, hanem ezen együtthatókat is szokás meghatározni [53-56]. Bizonyos 
minták, például csörpölt tükrök vagy speciális optikai szálak esetében a spektrális fázis nem jellemezhető Taylor-sorral. Ahogyan arra a mikrostruktúrált szálak diszperziós tulajdonságait bemutató 2.1.2 fejezetben utaltam, bizonyos esetekben a szálak transzmissziós spektrumában abszorpciós völgyek alakulnak ki [16], amelyek fázisugrások megjelenéséhez vezetnek. Ekkor a spektrális fázis nem közelíthető a fent bevezetett diszperziós koefficiensekkel. Ilyen esetekben előnyben kell részesíteni azokat a kiértékelési módszereket, melyek a fázist direkt módon, közelítések nélkül szolgáltatják. Fontos lenne továbbá megvizsgálni, hogy az ehhez hasonló, spektrális fázisban megjelenő irregularitások miként befolyásolják egy-egy kiértékelési eljárás pontosságát.

Optikai szálak diszperziójának jellemzésekor a szakirodalomban sokszor a $G D$-t, illetve a $G D D$-t, mint a körfrekvencia függvényét adják meg:

$$
\begin{gathered}
G D_{m}(\omega)=G D_{m}\left(\omega_{0}\right)+\left.\sum_{n=2}^{N} \frac{1}{(n-2) !} \frac{d^{n} \varphi_{m}}{d \omega^{n}}\right|_{\omega=\omega_{0}}\left(\omega-\omega_{0}\right)^{n-1}, \\
G D D_{m}(\omega)=G D D_{m}\left(\omega_{0}\right)+\left.\sum_{n=3}^{N} \frac{1}{(n-3) !} \frac{d^{n} \varphi_{m}}{d \omega^{n}}\right|_{\omega=\omega_{0}}\left(\omega-\omega_{0}\right)^{n-2},
\end{gathered}
$$

Sok esetben szokás a diszperziós paramétert $(D)$ is meghatározni:

$$
D(\omega)=-\frac{G D D_{m}(\omega) \cdot 2 \pi c}{\lambda^{2} L}
$$

ahol $\lambda$ a hullámhossz, $L$ az optikai szál hossza. Egy hagyományos optikai szál diszperziója bizonyos esetekben jó közelítéssel leírható egy kvarchasáb anyagi diszperziójának segítségével. Az ömlesztett kvarc törésmutató polinomjából [57] meghatározhatók adott központi körfrekvencián a fázisderiváltak, melyek például 800 nm-re vonatkoztatva rendre $G D D_{m}\left(\omega_{0}\right)=3616 \mathrm{fs}^{2}, T O D_{m}\left(\omega_{0}\right)=2749 \mathrm{fs}^{3}$ és $F O D_{m}\left(\omega_{0}\right)=-1143 \mathrm{fs}^{4} 10 \mathrm{~cm}$-es hasábbal számolva. Ahhoz, hogy a későbbiekben vizsgált mikrostruktúrált optikai szálak esetében a struktúra diszperziós együtthatókra gyakorolt hatását értékelni tudjuk, a (2.5)(2.7) összefüggések segítségével meghatároztam a $G D_{m}(\omega)$-, $G D D_{m}(\omega)$ - és $D(\omega)$ függvényeket a vizsgálandó 2.093-2.691 fs ${ }^{-1}$ frekvencia-, illetve az ennek megfelelő 700900 nm-es hullámhossztartományon. Ezek a 2.4 ábrán láthatók. 

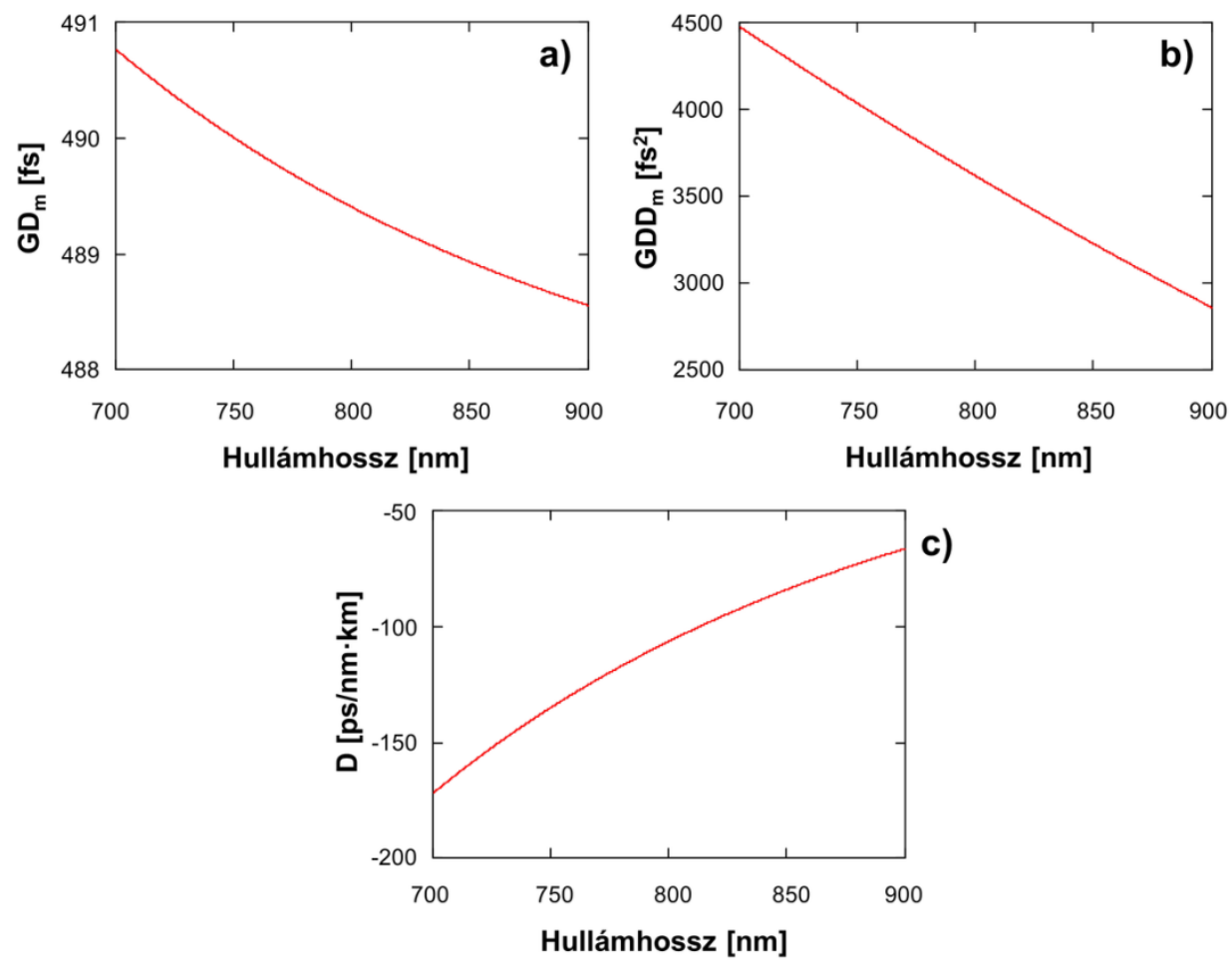

2.4 ábra $10 \mathrm{~cm}$ ömlesztett kvarchasáb (a) csoportkésleltetés, (b) csoportkésleltetés-diszperzió és (c) diszperziós görbéje.

\subsubsection{A dolgozatban vizsgált mikrostruktúrált szálak jellemzői}

Az alábbi alfejezetekben a dolgozat tárgyát képező két mikrostruktúrált szál sajátosságait mutatom be.

\subsubsection{Bragg-típusú optikai szál}

Munkám során elsőként egy megrendelésre készült, nagy móduskeresztmetszetü, üvegmagos Bragg-típusú szál diszperziós tulajdonságait vizsgálom meg. A szál előforma (preform) módosított kémiai gőzfázisú leválasztás (modified chemical vapor deposition, MCVD) módszerével készült. A szál aperiodikus Bragg-struktúrával rendelkezik, nyolc magasabb és alacsonyabb indexü réteg követi egymást a mag körül, melynek átméröje 8 $\mu \mathrm{m}$ körüli, törésmutatója pedig az alacsonyabb törésmutatójú rétegek indexével egyezik meg, szál tehát a PBG vezetés elvén müködik. A kisebb törésmutatójú rétegek indexe az ömlesztett kvarcéval megegyező, míg a magasabb indexü rétegeké mintegy 0.0125-tal nagyobb ennél a germánium adalékolása miatt. A gyártás során kialakuló törésmutatóátmenet a Ge diffúziója miatt igen egyenletes. A rétegek vastagsága a magtól számítva rétegröl-rétegre fokozatosan megközelítőleg 50\%-kal növekszik, aminek 
eredményeképpen előzetes szimulációk szerint a tiltott sáv $810 \mathrm{~nm}$ körül, néhány ún. szivárgó módus 783 és 813 nm-nél alakul ki. Korábbi eredmények azt mutatták, hogy a szivárgó módusok környezetében a szál transzmissziós spektrumában abszorpciós völgyek figyelhetők meg [16]. Az anomális diszperzió kifejezettebb hatásának következtében az elkészült Bragg-szál várhatóan a hagyományos egymódusú szálaknál jelentősen kisebb diszperzióval fog rendelkezni, aminek következtében a magasabb rendű diszperziók nagyobb jelentőséget kapnak. A leírtak értelmében tehát a diszperzió meghatározásához olyan technikára lesz szükség, amely képes a magasabb rendü diszperziók pontos mérésére, valamint kezelni tudja a spektrumban jelenlevő szivárgó módus okozta abszorpciókat.

\subsubsection{HC-800-02 fotonikus optikai szál}

A későbbiekben egy kereskedelmi forgalomban kapható légmagos fotonikus szál, nevezetesen a HC-800-02 PCF (NKT Photonics, [26]) diszperziós tulajdonságait vizsgálom meg. A szál egymódusúnak tekinthető, viszont két egymásra merőleges polarizációs módus terjedhet benne. Keresztmetszete a 2.5 ábrán látható.

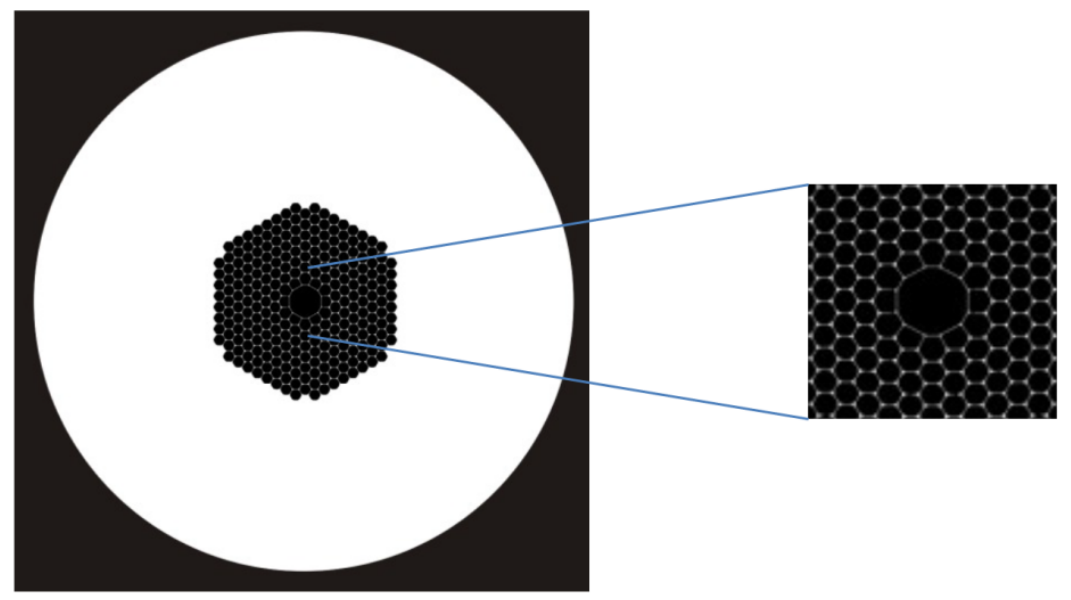

2.5 ábra A HC-800-02 típusú fotonikus optikai szál sematikus keresztmetszete [26].

Habár a szál anyaga kvarc, a fényterjedés körülbelül 95\%-ban levegöben történik. A mag átmérője $7.5 \mu \mathrm{m}$, a csatornák közötti távolság pedig $2.3 \mu \mathrm{m}$. Ahogyan az a szál elnevezésében is visszaköszön, 800 nm-re tervezték, müködési tartománya a 770-870 nmes hullámhossztartományt fedi le. A diszperzió tipikus értéke $820 \mathrm{~nm}$-en 100 ps/nm/km. Az anomális hullámvezető diszperzió miatt a szál kromatikus diszperziója a hagyományos 
egymódusú kvarc optikai szálakhoz képest várhatóan szintén kisebb lesz. A gyártó adatlapján bemutatott csillapításgörbe és diszperziós görbe a 2.6 ábrán látható.

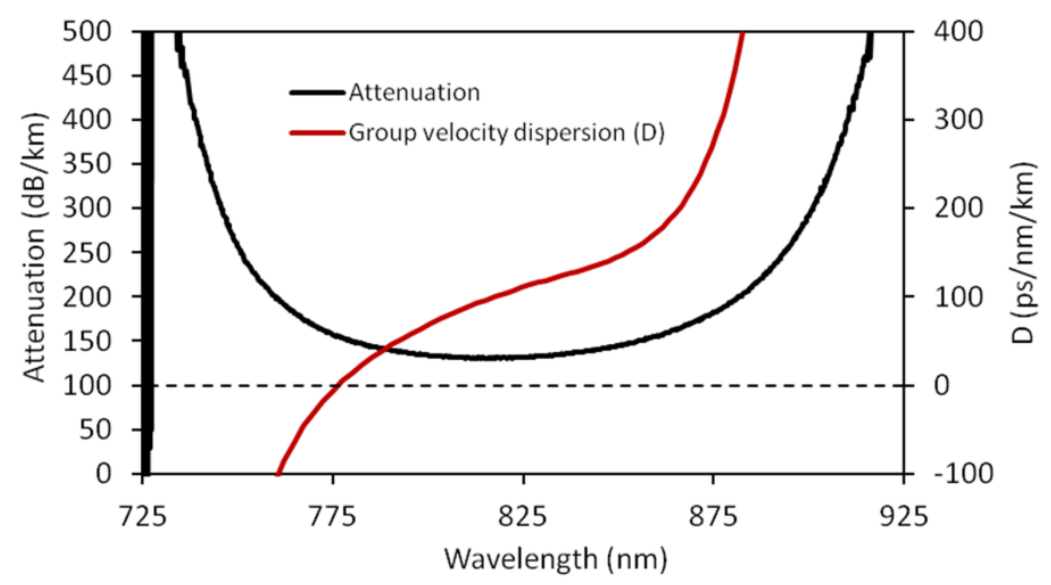

2.6 ábra A HC-800-02 típusú fotonikus optikai szál gyártó honlapján közzétett csillapításgörbéje (fekete) és diszperziója (piros) [26].

Tekintve, hogy ilyen speciális struktúrájú szálak esetén igazán nehéz garantálni, hogy a geometria tökéletes lesz gyártás után is, fontos lehet tehát megvizsgálni, hogy a szál kettőstörő-e, hiszen ahogyan azt a 2.1 fejezetben láthattuk, a hozzá igen hasonló geometriával rendelkező HC-800-01 típusú szál például kettőstörő [34]. Kettőstörő viselkedés esetén fontos a $D G D$ meghatározásai is. Szálstruktúrában jelenlevő hibák miatt előfordulhat továbbá, hogy különböző pozíciókban elhelyezett, avagy eltérő hosszúságú minták a tervezettől eltérő diszperziós és kettőstörő tulajdonságokkal rendelkezhetnek [7,20,30,34,36,40,58], így ennek vizsgálata is nagy jelentőséggel bír a szál alkalmazhatóságának szempontjából. Összefoglalva elmondható, hogy olyan mérési módszerre van szükségünk, aminek segítségével adott esetben nagypontossággal lehet polarizáció-, helyzet- és hosszfüggő diszperziót mérni. 


\subsection{Impulzusok időbeli alakjának meghatározására szolgáló módszerek osztályozása}

Ahogy korábban már említettem, ha egy lézerimpulzus diszperzív közegen halad keresztül, akkor a közegbeli terjedés során az impulzus időbeli alakja megváltozhat. Az előbbi fejezetben láttuk, hogy a mikrostruktúrált szálak a hagyományos optikai szálakhoz hasonlóan diszperzívek, de hozzájuk képest egészen eltérő diszperziós jellemzőkkel bírnak, azaz a rajtuk áthaladó impulzusok alakja a hagyományos szálakéhoz képest egészen szokatlan módon is megváltozhat. Ez viszont jelentősen befolyásolhatja a különböző mikrostruktúrált szálak alkalmazhatóságát. A mikrostruktúrált szálak impulzusokra gyakorolt hatásainak vizsgálatához különböző impulzus diagnosztikai technikák állnak rendelkezésre. Ezen technikák feloszthatók nemlineáris, önreferenciás, valamint lineáris, nem önreferenciás módszerekre [59] (2.7 ábra).

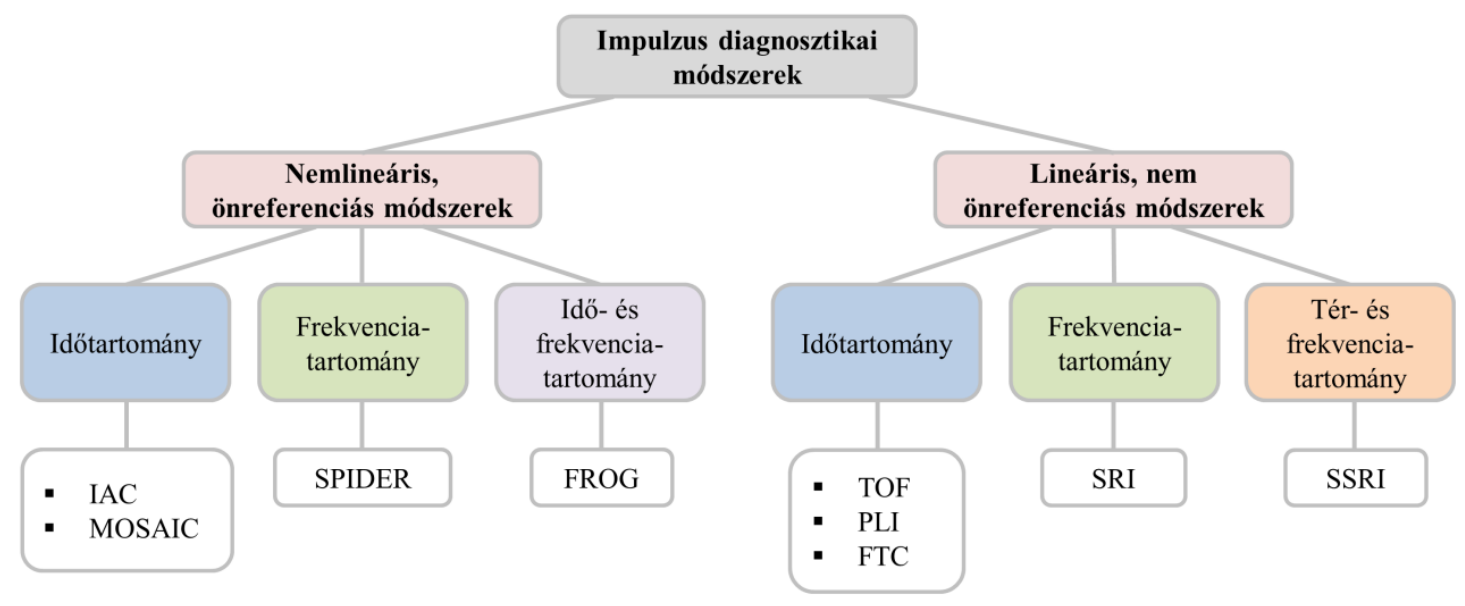

2.7 ábra Gyakran alkalmazott impulzus diagnosztikai módszerek csoportosítása.

Attól függően, hogy a mérés idő-, frekvencia- vagy idő- és frekvenciatartománybeli együttes karakterizálást tesz lehetővé, további csoportosítást végezhetünk. Ahogyan azt a következőkben látni fogjuk, egyes módszerek a spektrális fázis, míg mások a csoportkésleltetés (a spektrális fázis körfrekvencia szerinti első deriváltja, ld. 2.1.3 fejezet) meghatározását teszik lehetővé. Míg az önreferenciás technikák az említett karakterisztikák abszolút meghatározására alkalmasak, addig a nem önreferenciás módszerek csupán a relatív fázis vagy csoportkésleltetés mérését teszik lehetővé. Mivel számos esetben elég csak a relatív fázist illetve csoportkésleltetést ismerni, így napjainkban mindkét csoportba tartozó módszereket használják az adott kísérleti elrendezéstől, a laboratóriumban 
rendelkezésre álló eszközöktől, a hullámhossztartománytól és még egyéb más tényezőtől függően. Fontos persze kiemelni, hogy az impulzus időbeli alakja a nemlineáris módszerek esetében közvetett módon adódik, míg a lineáris technikák esetében ehhez biztosítani kell egy transzformlimitált referenciaimpulzust.

Az egyik legrégebbi, a spektrális fázis meghatározására alkalmas önreferenciás, időtartománybeli mérési módszer az interferometrikus autokorreláció (interferometric auto-correlation, IAC), melynek alkalmazásával az impulzus időbeli alakja is meghatározható, feltéve, ha az impulzus spektruma ismert. Előnye, hogy a különböző diszperziós koefficiensek dominanciája más és más mintázatot eredményez, ami diszperzió monitorozás szempontjából igen hasznos. Hátránya azonban, hogy érzéketlen a diszperzió elöjelére, illetve általában pontosságban is alul marad a többi módszerrel szemben [60]. Az IAC technikán alapuló további lehetséges megoldás lehet a módosított spektrumú autointerferometrikus korreláció (modified spectrum auto-interferometric correlation, MOSAIC) módszere. A MOSAIC nagyon érzékeny a csörp kimutatásának szempontjából még igen kis értékek esetén is, továbbá az IAC módszerhez hasonlóan nagy előnye, hogy mivel a különböző rendekhez más és más jelalak rendelhető, akár valósidejü diszperzió kontrollálásra is alkalmas lehet [61-64]. Tekintve, hogy egyes jelek elöállíthatók több csörp paraméter kombinációjával is, illetve, hogy ezen módszer sem érzékeny az időtengely irányítására, csupán kvalitatív analízisre alkalmas. Ha azonban nem csupán a MOSAIC módszerrel kapott az interferencia minimumok burkolójához tartozó amplitúdó meghatározására hagyatkozunk, hanem az időbeli jelalakot is meghatározzuk, kvantitatív diszperziómérésere is lehetőség nyílik. Ekkor az adott rendekhez tartozó diszperziós értékek iteratív eljárással meghatározhatók [62]. A processzus optimalizálására és az esetlegesen jelen lévő bizonytalanságok feloldására különböző módszereket dolgoztak ki. Ilyen például az E-MOSAIC algoritmus, amely valamely vezérlőszoftverrel (LabVIEW) kombinálva igen precíz, előjelszenzitív fázis meghatározást tesz lehetővé [64]. Amellett, hogy a módszer meglehetősen időigényes, jól látszik, hogy ilyen feltételek mellett nincs lehetőség valósidejü és egyben kvantitatív diszperzióanalízisre. Egy másik, szintén autokorreláción alapuló, idő- és frekvenciatartománybeli mérési technika az ún. frekvencia-bontott optikai kapuzás (Frequency Resolved Optical Gating, FROG), melynek több változata is használatos. Attól függően, hogy milyen nemlineáris folyamat alkalmazására épít, beszélhetünk polarizáción (polarization gating, PG), öndiffrakción (self-diffraction, SD), tranziens rácson (tranzient grating, TG), másod- (second-harmonic 
generation alapuló, SHG), valamit harmadik harmonikus keltésen (third-harmonic generation, THG) alapuló FROG-ról [65]. A PG FROG egy igen precíz technika, alkalmazásához azonban kiváló minőségü polarizátorokra van szükség, így igen költséges. Az SD FROG egy némileg olcsóbb megoldás, mely szintén harmadrendű nemlineáris folyamaton alapszik. Hátránya, hogy míg a páros rendủ időbeli torzulásokra igen érzékeny, a páratlanokra már kevésbé. A TG FROG alkalmazásához ugyan nincs szükség polarizátorokra, és pontosabb, mint az előzőekben felsorolt módszerek, azonban az, hogy három nyaláb előállítását és alkalmazását igényli kissé előnytelenné teszi a használatát. Az SHG FROG másodrendủ nemlineáris folyamaton alapul, így a segítségével előállított jel gyakran erősebb, érzékenysége azonban némileg alulmúlja még az IAC technika érzékenységét is, és ez is bizonytalan az időtengely előjelének szempontjából. A THG FROG ezzel szemben érzékeny az előjelre, cserébe viszont összességében véve kisebb érzékenységü technika. Habár érzékenysége még így is meghaladja a többi harmadrendü nemlinearitást felhasználó FROG módszernél tapasztaltakat, a fázis meghatározása bizonytalanságokkal terhelt, valamint lineáris csörp esetén nem tud elöjelinformációval szolgálni.

$\mathrm{Az}$ interferometrián alapuló módszerek ezzel szemben tipikusan kevesebb adatfeldolgozás mellett, aránylag gyors impulzuskarakterizálást tesznek lehetővé. Az egyik legismertebb technika az elektromos mező közvetlen rekonstruálásra szolgáló spektrális fázis-interferometria (spectral phase interferometry for direct electric field reconstruction, SPIDER) [66]. Habár kísérleti megvalósítása némileg bonyolultabb a korábbi módszerekhez képest, vezérléssel akár valósidejű impulzuskarakterizálásra is lehetőséget nyújt [67]. Stibenz és munkatársai tanulmányukban [68] megállapították, hogy a SPIDER összetettebb impulzusok esetében kevéssé megbízható, ellentétben az ún. SEA-SPIDER (spatially encoded arrangement for SPIDER) technikával, melynek hátránya azonban, hogy alkalmazásához sok adatra van szükség, ami miatt a kiértékelés időigényes.

Természetesen olyan interferometrikus technikák is léteznek, melyekhez nincs szükség nemlineáris kristályokra, és megvalósításuk tipikusan nem igényel bonyolult kísérleti elrendezéseket, illetve sokkal költséghatékonyabbak. Ilyen technika például a repülési idő-, a rögzített fázisú-, a Fourier-transzformációs korrelációs-, valamint az spektrális interferometria is $[28,29,69,70]$. A repülési idő (time-of-flight, TOF) interferometria [69,71-73] tipikusan egy szélessávú fényforrással kivilágított kétkarú 
interferométer és egy hangolható sávszürővel kiegészített fotoelektronsokszorozó alkalmazásán alapszik. Előnye a csoportkésleltetés közvetlen mérésében rejlik. Hátránya, hogy ha nagy sávszélességü fényforrást alkalmazunk, akkor a csoportkésleltetés ugyan nagy pontossággal, de alacsony spektrális felbontással határozható meg, illetve, hogy nagyon időigényes, hiszen ha több hullámhosszon szeretnénk a minta spektrális fázisáról információt kapni, akkor minden egyes hullámhosszon külön-külön kell a mérést végrehajtani. Az eljárás pontossága nagyon precíz eltolók és léptetőmotorok alkalmazásával növelhető ugyan, de ezzel együtt költségessé teszi azt. A rögzített fázisú interferometria (phase-locked interferometry, PLI) [69,74,75] sokban hasonlít az előző módszerre, azonban itt sávszürő helyett monokromátort használnak az interferométer kimeneténél. Tekintve, hogy piezo-eltoló és több Lock-in erősítő is szükséges hozzá, nem a legolcsóbb megoldás. A Fourier-transzformációs korrelációs (Fourier-transform correlation, FTC) módszer [56,69,76,77] abban különbözik a TOF és a PLI technikáktól, hogy ez esetben a detektor elé nem helyeztek sem sávszürőt, sem monokromátort, ezért a csoportkésleltetés a teljes spektrális tartományban meghatározható az intenzitás-késleltetés függvény Fourier-transzformáltjából. A módszer hátránya, hogy mérés sajátosságaiból adódó hibaforrások igen nagy hatással vannak a meghatározott csoportkésleltetés-függvény pontosságára, így ezek kiküszöbölése miatt vagy többször kell a mérést elvégezni, vagy a Fourier-transzformáció után kapott jelen kell simítást végrehajtani. Előbbi a méréshez szükséges idő növekedésével, utóbbi pedig a spektrális felbontás romlásához vezet. Emelett a fent ismertetett három időtartománybeli karakterizálást kihasználó módszer csupán hosszú szálminták esetén alkalmazható, ami fejlesztés alatt álló speciális szálak vizsgálatakor igen nagy hátránynak tekinthető.

A frekvenciatartománybeli interferometrián alapuló módszerek ezzel szemben nem igényelik hosszú szálak használatát, valamint sokkal precízebbek is. Aszerint, hogy a mérés csak frekvenciatartománybeli vagy tér- és frekvenciatartománybeli, megkülönböztetjük a spektrálisan bontott (spectrally resolved interferometry, SRI) [29] és a spektrálisan és térben bontott spektrális interferometriát (spectrally and spatially resolved interferometry, SSRI) [78-81]. Utóbbi módszer előnye, hogy a fázisfrontok térbeli döntése miatt az interferométer kimenetén olyan mintázat jön létre, melyböl szinte közvetlenül következtetni lehet a spektrális fázis alakjára, hátránya azonban, hogy egy kétdimenziós leképező spektrográf alkalmazását teszi szükségessé, melynek tipikusan kisebb a felbontása az egydimenziós detektálást alkalmazó módszerek esetében tapasztalt értéktől. 
Ezen megfontolásokból kutatásom során az SRI a mérési technikát alkalmaztam, melynek müködés elvét, valamint az alkalmazható kiértékelési eljárások sajátosságait a következő fejezetben részletesen ismertetem. 


\subsection{Spektrális interferometria}

A spektrálisan bontott interferometria egy széles körben alkalmazott mérési technika optikai elemek diszperziós jellemzőinek precíz meghatározására, akár magasabb rendü diszperziók esetén is [29]. Az alkalmazott kísérleti elrendezés alapját tipikusan egy kétkarú, leggyakrabban Mach-Zehnder vagy Michelson típusú interferométer képezi (2.8 és 2.9 ábra).

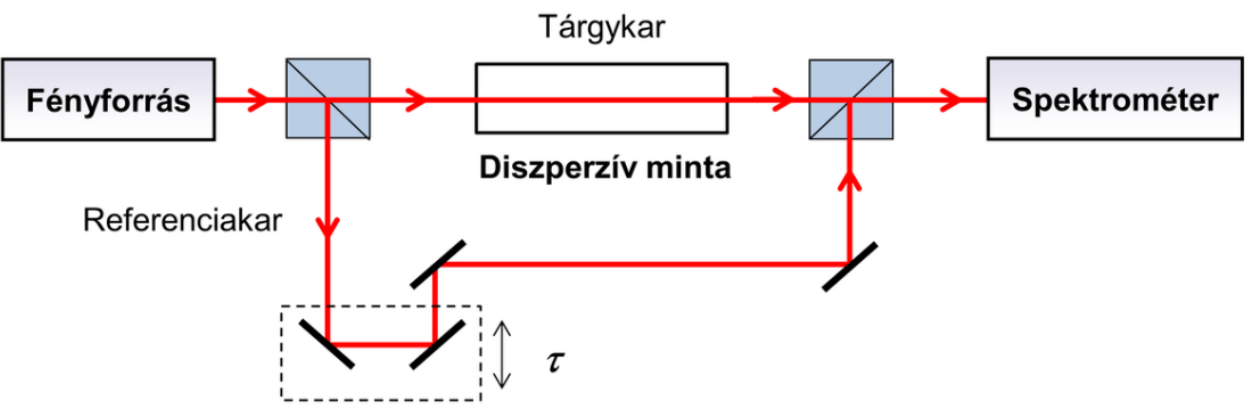

2.8 ábra Spektrálisan bontott Mach-Zehnder interferométer diszperzív mintával a tárgykarjában.

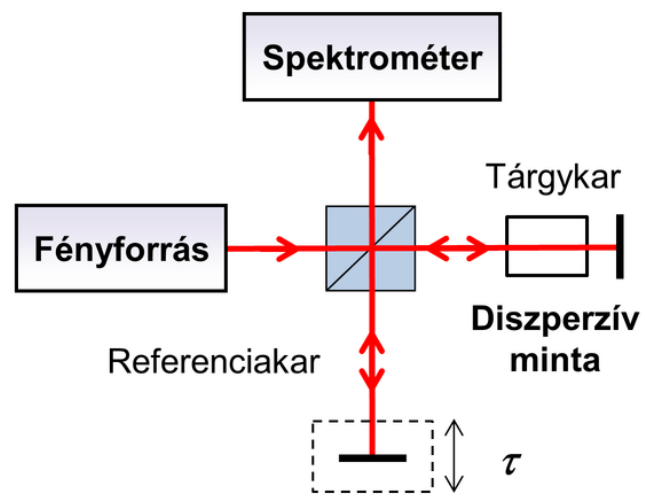

2.9 ábra Spektrálisan bontott Michelson interferométer diszperzív mintával a tárgykarjában.

Az elrendezés kivilágítása egy szélessávú fényforrással történik, ami lehet halogén lámpa, LED, erősített spontán emisszió, szuperkontinuum fényforrás vagy ultrarövid lézerimpulzus. A vizsgált optikai elem az interferométer egyik, ún. tárgykarjába kerül. A másik, ún. referenciakar hosszának változtatásával adott $\tau$ időbeli késleltetéseknél interferencia lép fel a két kar között, mely egy, az interferométer kimenetén elhelyezett spektrométer vagy spektrográf segítségével vizsgálható. Ekkor a kapott spektrálisan bontott interferogram intenzitásának körfrekvencia-függése a következőképpen írható fel: 


$$
I(\omega)=I_{t}(\omega)+I_{r}(\omega)+2 \sqrt{I_{t}(\omega) I_{r}(\omega)} \cos (\Phi(\omega))
$$

ahol $I_{t}(\omega)$ és $I_{r}(\omega)$ a tárgy- és a referenciakar spektrális intenzitásai. $\Phi$ a két kar között mérhető spektrális fáziskülönbség:

$$
\Phi(\omega)=\varphi_{m}(\omega)+\frac{\omega}{c}\left(l_{t}-l_{r}\right)=\varphi_{m}(\omega)+\omega \tau
$$

ahol $\varphi_{m}(\omega)$ a minta spektrális fázisa, $c$ a vákuumbeli fénysebesség, $\tau$ pedig a korábban már bevezetett időbeli késleltetés a két kar között, mely az egyes karok levegőben mért hosszkülönbségéből számítható.

A (2.3) egyenlethez hasonlóan az interferométer két karja közötti fáziskülönbség is Taylor-sorba fejthető az $\omega_{0}$ frekvencia körül:

$$
\Phi(\omega) \approx \Phi\left(\omega_{0}\right)+\left.\sum_{n=1}^{N} \frac{1}{n !} \frac{d^{n} \Phi}{d \omega^{n}}\right|_{\omega=\omega_{0}}\left(\omega-\omega_{0}\right)^{n},
$$

Az így kapott együtthatók és a minta spektrális fázisának Taylor-sorba fejtésével adódó együtthatók közötti kapcsolat (2.9) egyenlet alapján:

$$
\begin{gathered}
\Phi\left(\omega_{0}\right)=\varphi_{m}\left(\omega_{0}\right)+\omega_{0} \tau, \\
G D\left(\omega_{0}\right)=G D_{m}\left(\omega_{0}\right)+\tau, \\
G D D\left(\omega_{0}\right)=G D D_{m}\left(\omega_{0}\right), \\
T O D\left(\omega_{0}\right)=T O D_{m}\left(\omega_{0}\right), s t b .
\end{gathered}
$$

Jól látszik, hogy a fázis és a csoportkésleltetés esetében különbséget kell tenni pusztán a minta sajátosságaiból adódó $\left(\varphi_{m}\right.$ és $\left.G D_{m}\right)$, illetve az ezt és az interferométer két karja közötti különbségből adódó hatásokat is magába foglaló teljes $\Phi$ fázis és $G D$ között. A másod- és magasabb rendü deriváltak esetében nincs szükség erre, hiszen ezek nem függnek a $\tau$-tól. A továbbiakban ezért a $G D D$ és ennél magasabb rendü deriváltak esetében eltekintek az $m$ index használatától. 


\subsubsection{Kiértékelési módszerek}

A spektrálisan bontott interferogram kiértékelése különféle módszerekkel történhet. Több módszer alkalmazásának előfeltétele az ún. normált interferogramot előállítása, azaz:

$$
\cos (\Phi(\omega))=\frac{I(\omega)-I_{t}(\omega)-I_{r}(\omega)}{2 \sqrt{I_{t}(\omega) I_{r}(\omega)}}
$$

Ekkor egy állandó amplitúdójú interferogram áll elő, melyre a később ismertetendő fázismodulált koszinusz-függvény illesztésén alapuló kiértékelési módszer (cosine function fit, CFF) használatakor van szükség. A fenti normálás elvégzése azonban hasznos az állandó fázisú pont meghatározásán alapuló (stationary phase point method, SPP), valamint a minimum-maximum módszer (minima-maxima method, MM) esetén is, mivel a normálás által csökkenthető az intenzitásmaximumokban bekövetkező elcsúszás, amit az alkalmazott fényforrás nem teljesen állandó intenzitású spektruma okoz.

Megfigyelve, hogy milyen frekvenciánál lesz a spektrális intenzitásfüggvénynek szélsőértéke, két kiértékelési módszer adódik. Ehhez a (2.12) egyenlet frekvencia szerinti első deriváltja zérus kell, hogy legyen:

$$
\frac{d \cos (\Phi(\omega))}{d \omega}=-\sin (\Phi(\omega)) \cdot \frac{d \Phi}{d \omega}=0
$$

A fenti összefüggés két esetben teljesül. A $d \Phi / d \omega=0$ feltétel teljesülésén alapul az SPP-módszer, míg a $\sin (\Phi(\omega))=0$ feltétel alkalmazása az MM kiértékelési módszer alapját adja. Ezen módszerek és a dolgozatban alkalmazott egyéb kiértékelési eljárások részletesen a következő alfejezetekben kerülnek bemutatásra.

\subsubsection{1 Állandó fázisú pont módszere}

Az SPP-k meghatározásán alapuló módszert [82-86] gyakran használják különböző optikai elemek, köztük optikai szálak diszperziójának meghatározására [53,87-89].

A módszer alapelvének megértéséhez használjuk ki (2.11b) egyenletet. Ekkor a $G D$ az interferométer két karja közötti $\tau$ időbeli késleltetéséböl adódó csoportkésleltetés és a minta $G D_{m}$ csoportkésleltetésének összege, azaz: 


$$
G D(\omega)=G D_{m}(\omega)+\tau
$$

Azon körfrekvencia értéknél, ahol

$$
G D(\omega)=\frac{d \Phi}{d \omega}=0
$$

egy ún. állandó fázisú pont alakul ki, mely körül a fázis nagyon lassan változik. Átrendezve a (2.14) egyenletet és figyelembe véve az SPP kialakulásának feltételét, kapjuk, hogy

$$
G D_{m}(\omega)=\frac{d \varphi_{m}(\omega)}{d \omega}=-\tau
$$

azaz a minta csoportkésleltetése abszolút értékben pontosan megegyezik a két kar közötti $\tau$ késleltetéssel. A késleltetés változtatásával az SPP helyzete is változik, tekintve, hogy ekkor már más körfrekvenciaértéknél teljesül az SPP kialakulásának a (2.15) egyenlet által adott feltétele.

Vegyük észre, hogy a karok geometriai hosszából adódó $\tau$ késleltetés csak egy konstans $\tau_{0}$ erejéig ismert, azaz

$$
\tau=\frac{2\left(x-x_{0}\right)}{c}+\tau_{0}
$$

ahol $x_{0}$ a mikrométercsavar pozíciója a mérés kezdetekor, $x$ pedig az eltoló adott állása a mérés egy adott pillanatában, $\tau_{0}$ pedig az eltoló kiinduló $x_{0}$ pozíciójához tartozó időbeli késleltetés, melyet általában nem ismerünk. A (2.14) és (2.17) egyenletek alapján látható, hogy ezzel a módszerrel tehát csak a minta relatív csoportkésleltetés-függvénye mérhető meg, azaz

$$
G D(\omega)=G D_{m}(\omega)+2 \frac{x-x_{0}}{c}+\tau_{0}
$$

Ha változtatjuk az $x$ - $x_{0}$ geometriai úthosszkülönbséget, azaz $\tau$ változik, akkor az interferogramok kiértékelésekor kirajzolódó $G D(\omega)$-függvény alakját tekintve 
megegyezik a meghatározandó, mintára jellemző $G D_{m}(\omega)$-függvénnyel egy $\tau$ konstans eltolás erejéig. Tekintve, hogy az impulzus torzulásáért felelős magasabb rendü együtthatók viszont már függetlenek $\tau$-tól, ahogyan erre a (2.11)-ben is utaltam

$$
\begin{gathered}
\frac{d G D(\omega)}{d \omega}=G D D_{m}(\omega) \\
\frac{d^{2} G D(\omega)}{d \omega^{2}}=T O D_{m}(\omega) \text { stb. }
\end{gathered}
$$

ezek valóban a mintára jellemző fázisderiváltakat adják meg.

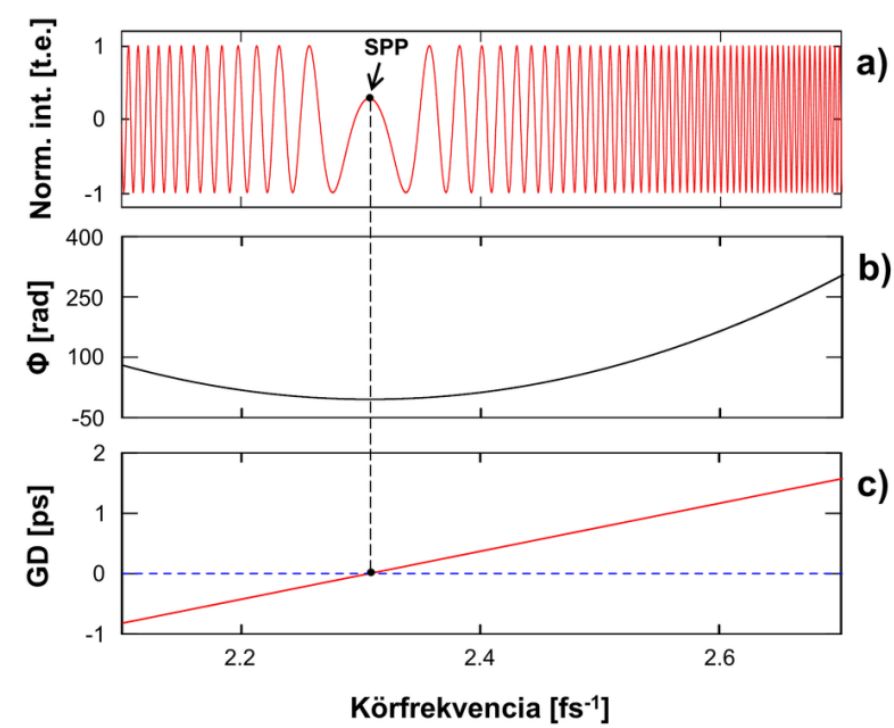

2.10 ábra Pozitív, tisztán másodrendű diszperzió $\left(\varphi_{m}\left(\omega_{0}\right)=0, G D_{m}\left(\omega_{0}\right)=200 \mathrm{fs}, G D D\left(\omega_{0}\right)=4000 \mathrm{fs}^{2}, \tau=0\right)$ esete: (a) szimulált normált interferogram egy állandó fázisú ponttal, (b) a hozzá tartozó fázisgörbe és (c) csoportkésleltetés-görbe.

Pozitív, tisztán másodrendü diszperziót feltételezve a 2.10 a) ábrán egy MathCad 14 szoftver segítségével szimulált interferogram látható, az SPP feltüntetésével. A szintén szimuláció eredményeképpen kapott fázisgörbe és csoportkésleltetés-görbe ez esetben a 2.10 b) és c) ábrán látható. Jól látszik, hogy ahol az SPP megjelenik, ott a $G D(\omega)$, vagyis a spektrális fázis első deriváltja a nulla értéket veszi fel.

Az itt vizsgált másodrendü diszperzió esetét tekintve, a fentiekből következik, hogy miután különböző karhosszaknál meghatározzuk az SPP helyzetét, a 2.11 és 2.12 ábrákon is kirajzolódó $G D(\omega)$-függvény adódik [53,82,87,88]. Pozitív másodrendű diszperzió 
esetén, azaz ha a nagyobb frekvenciájú komponensek az impulzus végén találhatók, a referenciakar hosszának növelésével, azaz a két kar közötti relatív $\tau$ késleltetés csökkenésével az SPP az interferogramon a nagyobb frekvenciák felé mozdul el (2.11 ábra). Ezzel szemben negatív $G D D$ esetén, amikor a nagyobb frekvenciájú komponensek az impulzus elején találhatók, a referenciakar hosszának növekedésével az SPP a kisebb frekvenciák irányába mozdul el (2.12 ábra). Habár az előbbi eset a gyakoribb, egyes optikai elemek, mint például az ún. grism párok [90] és speciális optikai szálak rendelkezhetnek domináns negatív $G D D$-vel.

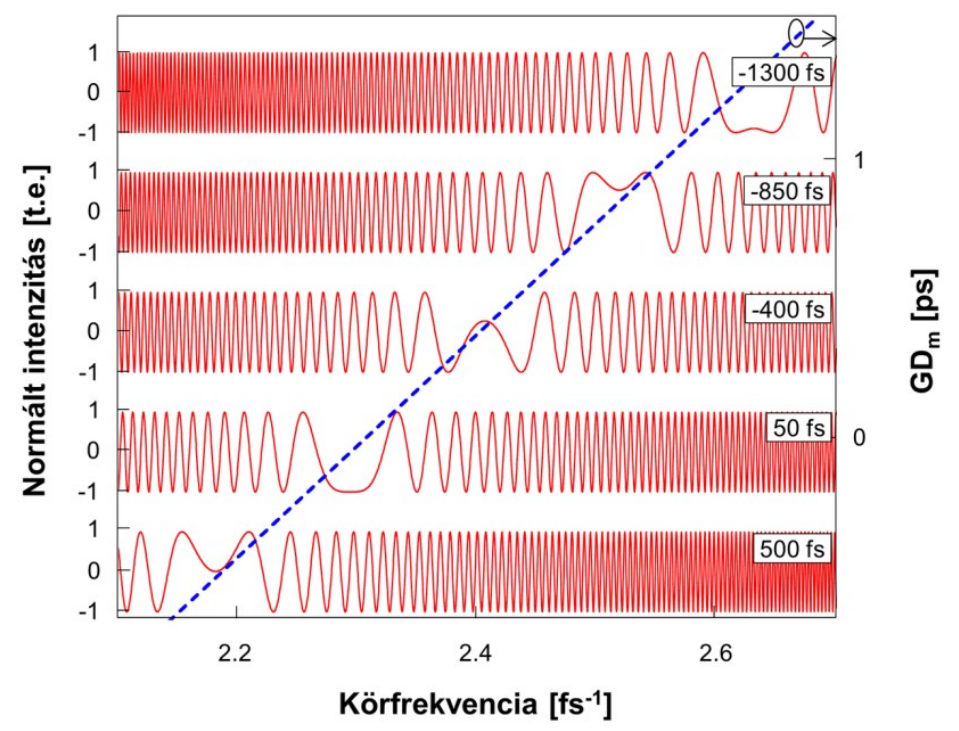

2.11 ábra Az állandó fázisú pont mozgása a késleltetés változtatásával pozitív, tisztán másodrendű diszperzió $\left(\varphi_{m}\left(\omega_{0}\right)=0, G D_{m}\left(\omega_{0}\right)=200 \mathrm{fs}, G D D\left(\omega_{0}\right)=4000 \mathrm{fs}^{2}\right)$ esetén. A referenciakar hossza alulról felfelé növekszik, míg a relatív időbeli késleltetés csökken.

A fentiekből látszik, hogy az SPP-k mozgásának követéséböl könnyen következtetni lehet a $G D$ elöjelére, és számértékére egyaránt. A $G D$-görbére történő polinomillesztés után a diszperziós együtthatók tetszőleges rendig meghatározhatók. Például, ha a $G D(\omega)$-görbére egy ötödfokú polinomot illesztünk, a diszperziós koefficienseket hatodrendig tudjuk meghatározni:

$$
G D_{i l l}=a_{0}+a_{1} \Delta \omega+a_{2} \Delta \omega^{2}+a_{3} \Delta \omega^{3}+a_{4} \Delta \omega^{4}+a_{5} \Delta \omega^{5},
$$

ahol $a_{0}, a_{1}, \ldots$ illesztési paraméterek és $\Delta \omega=\omega-\omega_{0}$. Az illesztési paraméterekből következtetni lehet a fázisderiváltak értékeire, ugyanis $G D\left(\omega_{0}\right)=a_{0}, G D D\left(\omega_{0}\right)=a_{1}$, $\operatorname{TOD}\left(\omega_{0}\right)=2 a_{2}, F O D\left(\omega_{0}\right)=6 a_{3}, Q O D\left(\omega_{0}\right)=24 a_{4}$ és $S O D\left(\omega_{0}\right)=120 a_{5}$. 


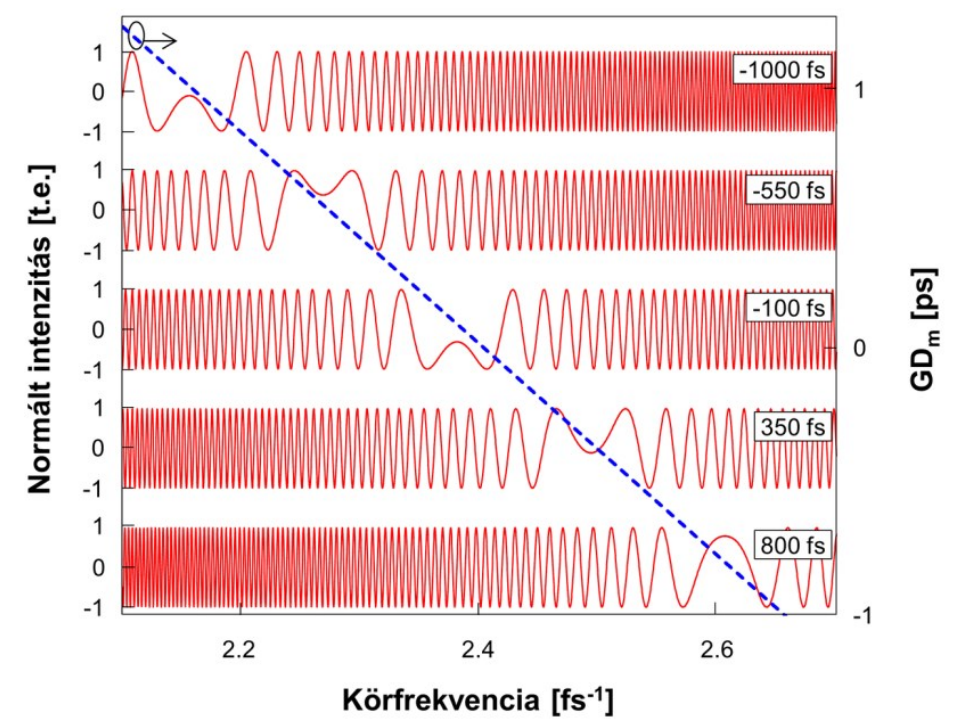

2.12 ábra Az állandó fázisú pont mozgása a késleltetés változtatásával negatív, tisztán másodrendü diszperzió $\left(\varphi_{m}\left(\omega_{0}\right)=0, G D_{m}\left(\omega_{0}\right)=200 \mathrm{fs}, G D D\left(\omega_{0}\right)=-4000 \mathrm{fs}^{2}\right)$ esetén. A referenciakar hossza alulról felfelé növekszik, míg a relatív időbeli késleltetés csökken.

A fenti szimulációk egy olyan fázisfüggvény feltételezésével készültek, mely csak másodrendü diszperziót tartalmazott. Tekintve, hogy az optikai elemeknek általában TOD járuléka is van, egy valósághoz közelebbi esetet mutat be a 2.13 és 2.14 ábra, mely az ömlesztett kvarcra jellemző $G D D\left(\omega_{0}\right)$ és $T O D\left(\omega_{0}\right)$ értékek [57] felhasználásával készült.

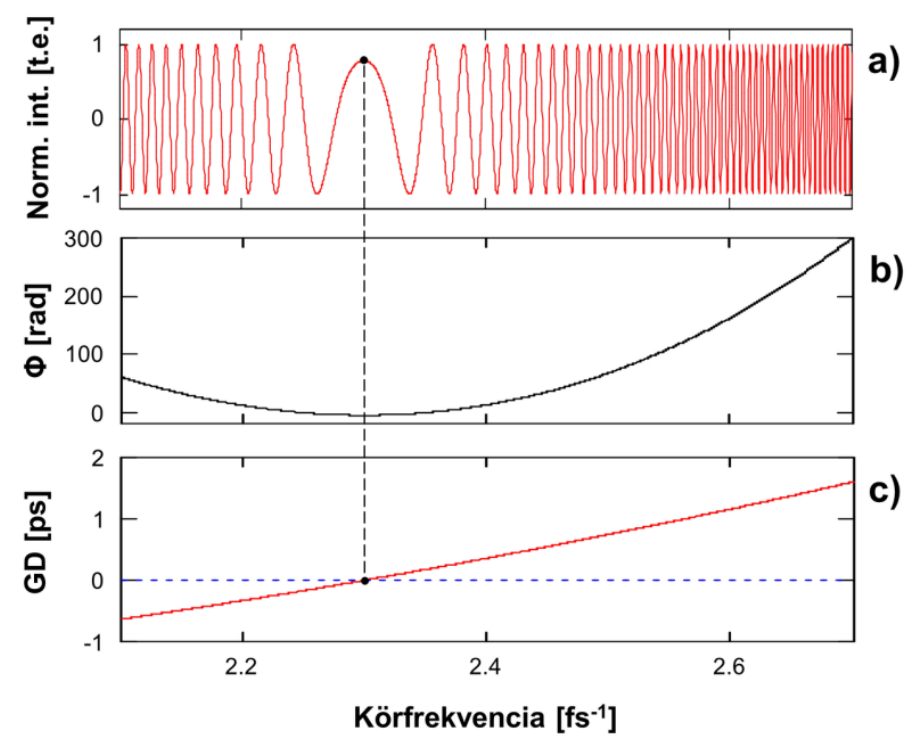

2.13 ábra $10 \mathrm{~cm}$ ömlesztett kvarchasáb $\left(\varphi_{m}\left(\omega_{0}\right)=0, G D_{m}\left(\omega_{0}\right)=200 \mathrm{fs}, G D D\left(\omega_{0}\right)=3616 \mathrm{fs}^{2}, T O D\left(\omega_{0}\right)=2749 \mathrm{fs}^{3}\right.$, $\tau=0$ ) esete: (a) szimulált normált interferogram egy állandó fázisú ponttal, (b) a hozzá tartozó fázisgörbe és (c) csoportkésleltetés-görbe. 
Jól látszik, hogy bár az interferogram, a fázisgörbe és a $G D(\omega)$-görbe is nagyon hasonlít a pusztán másodrendủ diszperziót feltételező korábbi esethez, azonban a $G D$ görbe némileg eltér a lineáristól. Látszik, hogy ahhoz, hogy két ehhez hasonló esetet teljes bizonyossággal megkülönböztessünk egymástól, nem elég csak a fázis- vagy a $G D(\omega)$ görbét meghatározni, hanem illesztéssel az együtthatókat is fontos megadni.

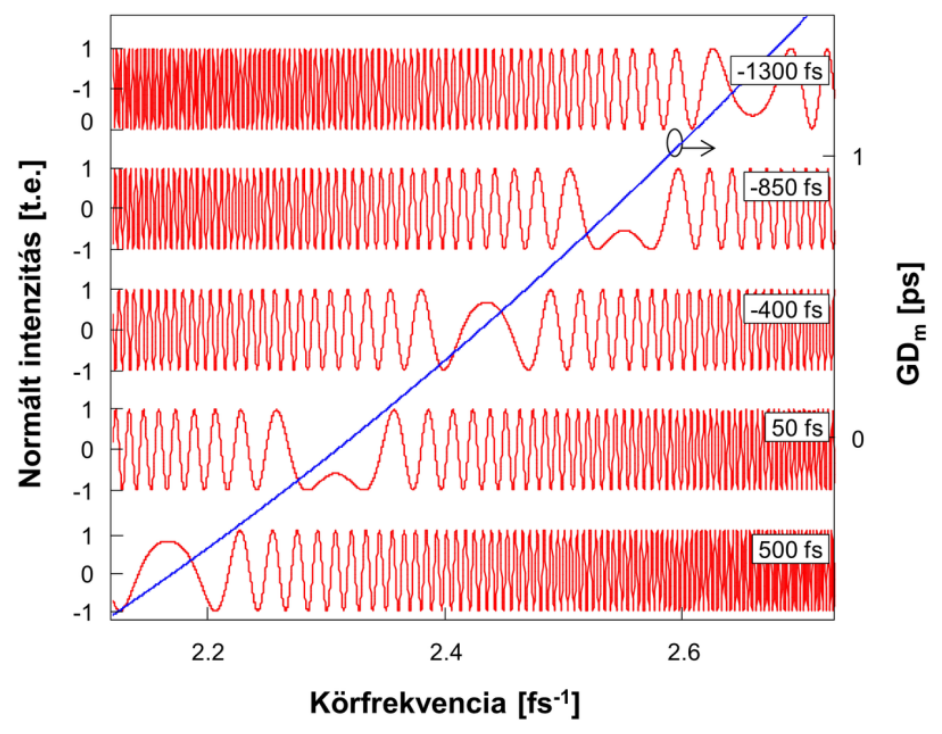

2.14 ábra Az állandó fázisú pont mozgása a késleltetés változtatásával $10 \mathrm{~cm}$ ömlesztett kvarchasáb esetén $\left(\varphi_{m}\left(\omega_{0}\right)=0, G D_{m}\left(\omega_{0}\right)=200 \mathrm{fs}, G D D\left(\omega_{0}\right)=3616 \mathrm{fs}^{2}, T O D\left(\omega_{0}\right)=2749 \mathrm{fs}^{3}\right)$. A referenciakar hossza alulról felfelé növekszik, míg a relatív időbeli késleltetés csökken.

Nagy diszperziók esetén, például optikai szálaknál az interferogram bizonyos részein olyannyira besürüsödhet a csíkrendszer, hogy a spektrométer már nem lesz képes felbontani. Ilyen esetekben a diszperzió meghatározása sokszor csak az SPP-módszer alkalmazásával lehetséges [85]. Ennek értelmében tehát a módszer akkor is jól müködik, ha nagyobb hullámhossztartományban szeretnénk diszperziót mérni, ami miatt kénytelenek vagyunk kisebb felbontású spektrométerrel dolgozni. A módszer hátránya azonban, hogy aránylag sok interferogram felvételét és kiértékelését igényli, ami viszonylag időigényes. Továbbá, tekintve, hogy az SPP kis diszperziók esetén kiszélesedhet, a pontos helyzetét nem lehet megmondani, azaz a módszer pontatlanná válik.

Az SPP-módszert eleinte leginkább olyan optikai elemek és szálak diszperziójának mérésére használták, melyek spektrális fázisában a $G D D$ dominált, viszont olyan optikai szálak esetében, melyeknél a $G D D$ csökkentése a cél, inkább az ennél magasabb rendek lesznek dominánsak. Mivel a (2.16) egyenlet alapján ekkor több SPP megjelenésére is 
lehet számítani, fontos lenne megvizsgálni, hogy ezek számából, mozgásából, valamint alakjából mennyire tudunk következtetni egy adott diszperziós rend dominanciájára, főként, mert ezzel lehetőség lenne a diszperzió monitorozására akár valós időben is. Korábban egy, az SPP-módszeren alapuló kétdimenziós technikát már sikerült diszperzió monitorozásra használni impulzus-nyújtó és -kompresszor rendszerben, harmadrendü diszperziót vizsgálva [78]. Ezen eredmények alapján, az SPP-módszer alkalmasnak tűnik valósidejü diszperzió analízisre, akár egy kisebb felbontású spektrométer alkalmazásával is, olcsóbbá téve ezáltal a mérés megvalósítását.

\subsubsection{Minimum-maximum módszer}

A MM-módszert [54,87,91-93] korábban már sikeresen alkalmazták fotonikus optikai szálak vizsgálatára is [91]. A módszer alapelvének megértéséhez induljunk ki a (2.13) egyenlet másik feltételének teljesüléséből, azaz hogy $\sin (\Phi(\omega))=0$. Ezen összefüggés az interferogram intenzitás-minimumainak és -maximumainak pozícióit adja meg. A szélsőértékek azon körfrekvenciaértékeknél alakulnak ki, ahol $\Phi$ a $\pi$ egész számú többszörösével egyezik meg. A kiértékelés első lépése az interferogram normálása, majd az intenzitás-minimumokhoz és -maximumokhoz tartozó körfrekvenciaértékek meghatározása következik. Ahhoz, hogy ezekhez fázisértéket rendeljünk hozzá, a minimumok és maximumok rendjét $\pi$-vel kell megszorozni (2.15 ábra).

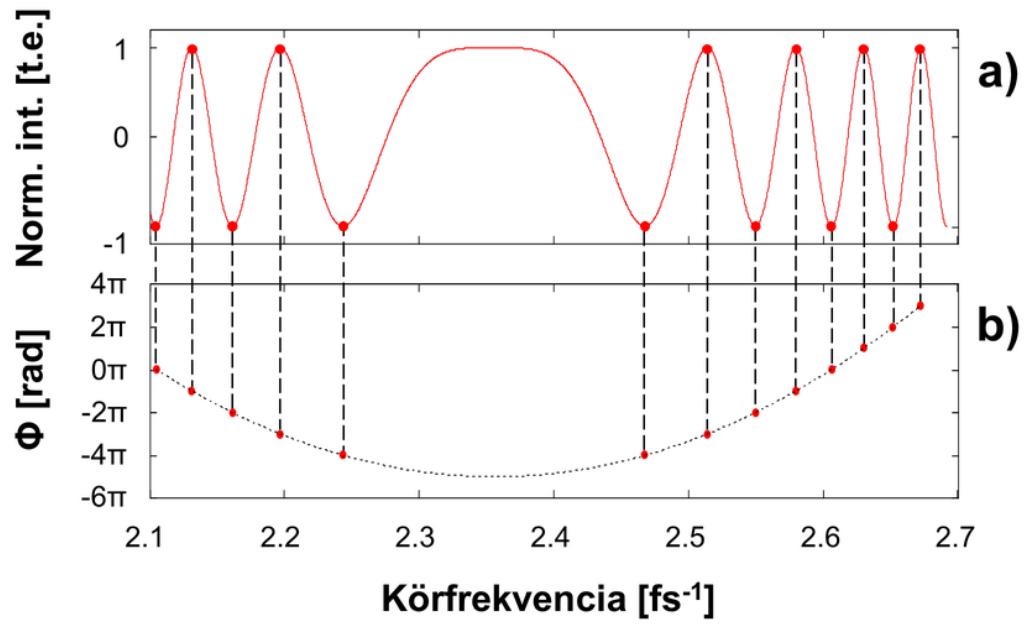

2.15 ábra (a) Szimulált normált interferogram a szélsőértékek megjelölésével és (b) a meghatározott fázisgörbe illesztéssel. 
Ha az eredményül kapott fázisértékeket a körfrekvencia függvényében ábrázoljuk, és erre polinomot illesztünk, akkor az illesztés paraméterei megadják a minta diszperziós koefficienseit:

$$
\Phi_{i l l}=b_{0}+b_{1} \Delta \omega+b_{2} \Delta \omega^{2}+b_{3} \Delta \omega^{3}+b_{4} \Delta \omega^{4}+b_{5} \Delta \omega^{5}+b_{6} \Delta \omega^{6}
$$

ahol $b_{0}, b_{1}, \ldots$ illesztési paraméterek, és a diszperziót hatodrendig vizsgálva, $G D\left(\omega_{0}\right)=b_{1}$, $G D D\left(\omega_{0}\right)=2 b_{2}, T O D\left(\omega_{0}\right)=6 b_{3}, F O D\left(\omega_{0}\right)=24 b_{4}, Q O D\left(\omega_{0}\right)=120 b_{5}$ és $S O D\left(\omega_{0}\right)=720 b_{6}$.

A MM-módszer előnye, hogy viszonylag kevéssé érzékeny a zajra, illetve, hogy egyetlen interferogram felvétele és kiértékelése elegendő a diszperzió meghatározásához. Az interferogram normáláshoz természetesen még szükséges a tárgykar és a referenciakar spektrumának rögzítése is. A módszer hátránya, hogy mivel a koszinusz-függvény páratlan, a fázisderiváltak előjelének meghatározásához legalább egy további interferogram kiértékelése szükséges. A kiértékelés sajátosságából adódik továbbá, hogy az elérhető spektrális felbontás igen alacsony, illetve, hogy mivel nehezen automatizálható, ezért hosszadalmas.

\subsubsection{Fázismodulált harmonikus függvény illesztése}

A CFF kiértékelési eljárás is bizonyítottan alkalmas mikrostruktúrált szálak diszperziójának és törésmutatójának meghatározására is [55,94]. A módszer lényege, hogy a normált interferogram előállítása után egy megfelelő fokszámú fázismodulált koszinuszfüggvény illesztésével (2.16 ábra) a diszperziós koefficiensek szintén meghatározhatók:

$$
I_{\text {ill }}=c_{1}+c_{2} \cos \left(b_{0}+b_{1} \Delta \omega+b_{2} \Delta \omega^{2}+b_{3} \Delta \omega^{3}+b_{4} \Delta \omega^{4}+b_{5} \Delta \omega^{5}+b_{6} \Delta \omega^{6}\right)
$$

ahol $b_{0}, b_{1}, \ldots$ együtthatók a MM-módszernél is alkalmazott jelentéssel bírnak, $c_{1}$ és $c_{2}$ pedig illesztési paraméterek.

A CFF-módszer előnye, hogy a tárgykar és a referenciakar spektrumának rögzítése mellett szintén csupán egy interferogram kiértékelése szükséges a vizsgált minta diszperziójának meghatározásához, azonban a korábban említett okokból az előjel megadásához szükséges egy további interferogram kiértékelése is. A módszer hátránya, hogy ha nagy diszperziók mérése esetén a csíkrendszer besürüsödik és emiatt az amplitúdóértékek hullámhosszfüggővé válnak, akkor pontatlanná válik az illesztés. 


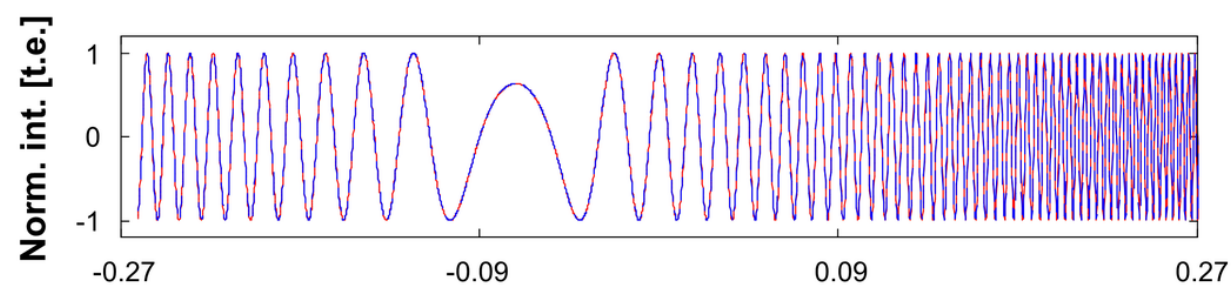

Rel. körfrekvencia [fs $\left.{ }^{-1}\right]$

2.16 ábra Szimulált normált interferogram (piros) a ráillesztett fázismodulált koszinusz-függvénnyel (kék).

\subsubsection{Fourier-transzformációs módszer}

A felvett interferogram kiértékelése a fent ismertetett módszereken kívül történhet még Fourier-transzformáción (Fourier-transform, FT) alapuló adatfeldolgozással is [52,95-102] Az FT-módszert gyakran alkalmazzák tükrök és üveghasábok diszperziójának [97], valamint mikrostruktúrált [52] és diszperzió-kompenzált optikai szálak [101] spektrális fázisának meghatározására is. Alkalmazásához nagy, tipikusan pikoszekundumos késleltetéseknél felvett interferogramok szükségesek (2.17 a) ábra). Első lépésként egy inverz Fourier-transzformációt kell végezni a felvett interferogramon:

$$
F\{I(\omega)\}=F\left\{I_{t}(\omega)\right\}+F\left\{I_{r}(\omega)\right\}+F\left\{2 \sqrt{I_{t}(\omega) \cdot I_{r}(\omega) \cdot} \cos (\Phi(\omega))\right\}
$$

Ekkor az időtartományban kapott jelet az alábbi összefüggés adja meg:

$$
I(t)=I_{t}(t)+I_{r}(t)+I_{i}\left(t-\tau^{\prime}\right)+I_{i}\left(t+\tau^{\prime}\right)
$$

ahol $I(t), I_{t}(t)$ és $I_{r}(t)$ rendre az $I(\omega), I_{t}(\omega)$ és $I_{r}(\omega)$ Fourier-transzformáltjai. A referenciavalamint a tárgykarból érkező impulzusok $\left(I_{t}(\omega)\right.$ és $\left.I_{r}(\omega)\right)$ spektrális intenzitása $\omega$-ban lassan változó függvény, így a megfelelő Fourier-transzformáltjaik $\left(I_{t}(t)\right.$ és $\left.I_{r}(t)\right)$ a $t=0$ körül jelennek meg (2.17 b) ábra). Az interferencia tagok Fourier-transzformáltjai $\left(I_{i}\left(t-\tau^{\prime}\right)\right.$ és $\left.I_{i}\left(t+\tau^{\prime}\right)\right) \omega$-ban gyorsan változó függvények, ezek a $\tau^{\prime}$ és $-\tau^{\prime}$ késleltetéseknél jelennek meg $\left(2.17\right.$ b) ábra). $\tau^{\prime}$ a tárgy- illetve a referenciakarból érkező két impulzus közötti időbeli késést jelöli, mely két részből tevődik össze: a két kar geometriai útkülönbségéből származó $\tau$ időkésésből, illetve a minta fázistolásából adódó késleltetéséből. Vegyük észre, hogy a két $t=0$-ra szimmetrikus csúcs megjelenésének oka, hogy a Fourier-transzformáció valós függvényen történt. A kiértékelés következő lépése a pozitív késleltetéshez tartozó $\left(I_{i}\left(t-\tau^{\prime}\right)\right)$ csúcs kivágása, majd egy Fourier-transzformáció elvégzése ezen a jelen. A kapott 
függvény argumentumából a mintára jellemző fázisfüggvény egyszerüen meghatározható (2.17 c) ábra), valamint polinomillesztéssel a fázisderiváltak is kiszámolhatók.

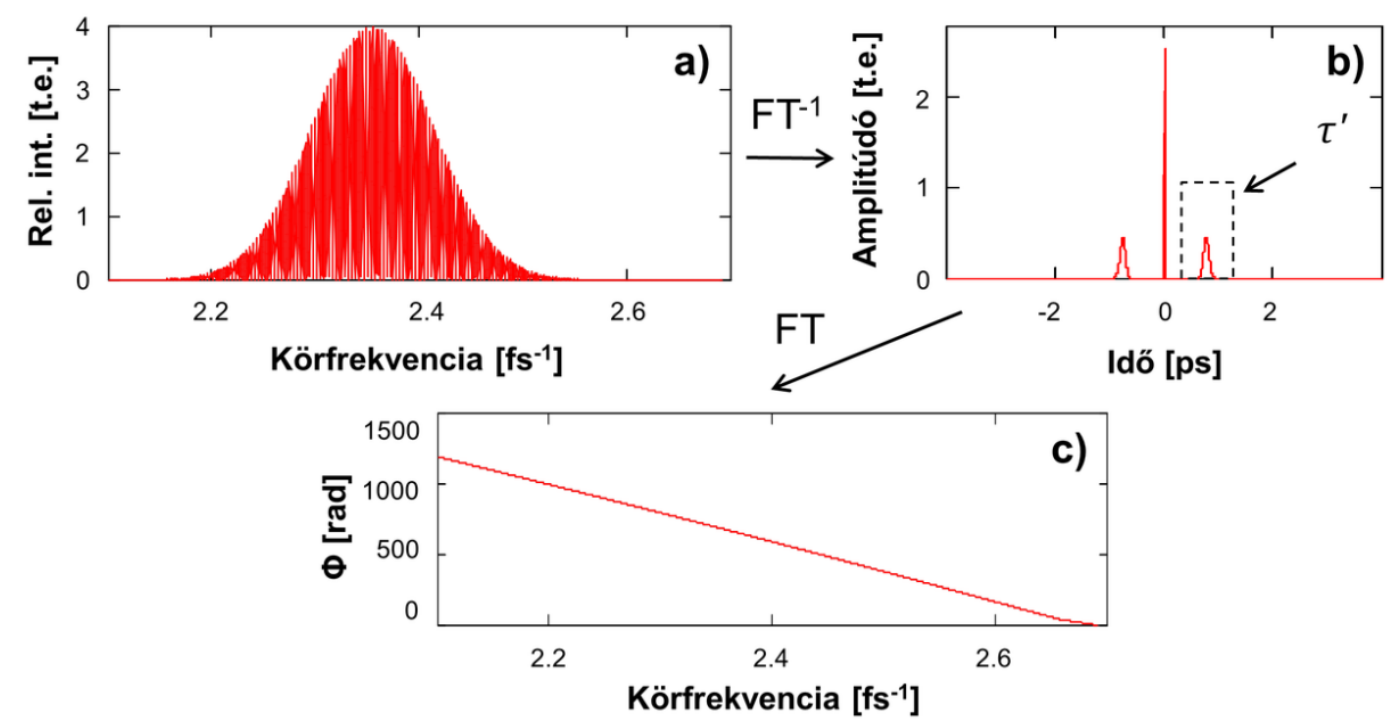

2.17 ábra (a) Szimulált interferogram és (b) Fourier-transzformáltja. (c) A kapott fázisgörbe.

Az FT-módszer előnye, hogy nem igényli a tárgykar és a referenciakar spektrumának felvételét, csupán egyetlen interferogram szükséges a kiértékeléshez. Az elöjel meghatározásához ebben az esetben is minimum egy további interferogram felvétele szükséges. Az FT-módszer segítségével a fázis direkt módon meghatározható, nem szükséges feltenni, hogy polinommal közelíthető, ami igen előnyös lehet komplex, például abszorpciós völgyeket is tartalmazó fázisfüggvénnyel rendelkező minták vizsgálatakor.

\subsubsection{Ablakolt Fourier-transzformációs módszer}

Az előző fejezetben ismertetett kiértékelési eljáráshoz hasonló a profilometriában gyakran használt [100,102-106] ún. ablakolt Fourier-transzformációs (windowed Fouriertransform, WFT) módszer. Attól függően, hogy a kapott jel kiértékelése hogyan történik, kétféle WFT-módszert különböztetünk meg [102,103,106]. Az egyik megközelítés az ablakolt Fourier-szürésen (windowed Fourier-filtering, WFF) [100,107,108], a másik pedig az ablakolt Fourier-transzformáción alapuló gerincvonal kereső (windowed Fourier-ridges, WFR) algoritmus [104,105] A WFT-módszer egyik legkritikusabb pontja a megfelelő ablakfüggévny megválasztása, mely témában több publikáció is született [104,105]. A WFF-módszert sikeresen alkalmazták nyalábosztó kockák [106,107] és tükrök [109,110] spektrális fázisának meghatározására, valamint polarizációtartó optikai szálak $D G D$-jének 
mérésére is [108]. Nicholson és munkatársai egy ehhez nagyon hasonló, ún. mozgó WFTmódszert (sliding window Fourier-transform) használtak 1550 nm-re tervezett légmagos fotonikus optikai szálak módusstruktúrájának feltérképezésére [111], azonban a WFT itt voltaképpen csak vizuális eszközként szolgált, kvantitatív értelemben diszperziómérésre nem használták. A WFR algoritmust ezzel szemben sikerrel alkalmazták lebegési hossz (beat length) valamint csoporttörésmutató meghatározására is nagy kettőstörésủ légmagos fotonikus szálak esetében is alacsony spektrális felbontás mellett [42]. Az említett két módszeren kívül, spektrális fázis meghatározására alkalmas a wavelet-transzformáció elvén müködő kiértékelés szintén a gerincvonal keresésén alapuló változata is [112]. Az FT-, WFT- és wavelet-transzformációs módszereket szimulációk [103,104] és mérések [100,102] segítségével történő összehasonlítása rámutatott, hogy a wavelet-módszer kevéssé alkalmas interferenciamintázatok analizálására, ugyanis ez esetben az eredmények jelentős zajjal terheltek.

Munkám során a WFR-módszert használtam, így az alábbiakban ezt mutatom be részletesen. Ez esetben szintén nagy késleltetések beállítása mellett felvett interferogramra lesz szükségünk (2.18 a) ábra). A WFT-módszer első lépéseként a felvett interferogramon egy inverz Fourier-transzformációt hajtunk végre, melyet előzőleg egy ablakfüggvénnyel szoroztunk meg:

$$
W_{I}(\Omega, t)=\int_{-\infty}^{\infty} I(\omega) g(\omega-\Omega) \exp (i \omega t) d \omega
$$

ahol

$$
g(\omega-\Omega)=\exp \left[-\left(\frac{\omega-\Omega}{\Delta \Omega}\right)^{2}\right]
$$

jelöli az ablakfüggvényt, $\Omega$ a központi frekvencia, $\Delta \Omega$ pedig az ablakfüggvény szélessége. Ahogyan az ablakfüggvény központi frekvenciáját változtatjuk, egy sorozat ablakolt interferogramot kapunk (2.18 b) ábra). Bevezetve az $a(\omega)=I_{t}(\omega)+I_{r}(\omega)$ és a $b(\omega)=2 \sqrt{I_{t}(\omega) I_{r}(\omega)}$ jelöléseket, valamint az interferenciát leíró képletet átírva az Eulerösszefüggéseket alkalmazva, kapjuk, hogy 


$$
I(\omega)=a(\omega)+\frac{b(\omega)}{2} \exp (i \Phi(\omega))+\frac{b(\omega)}{2} \exp (-i \Phi(\omega))
$$
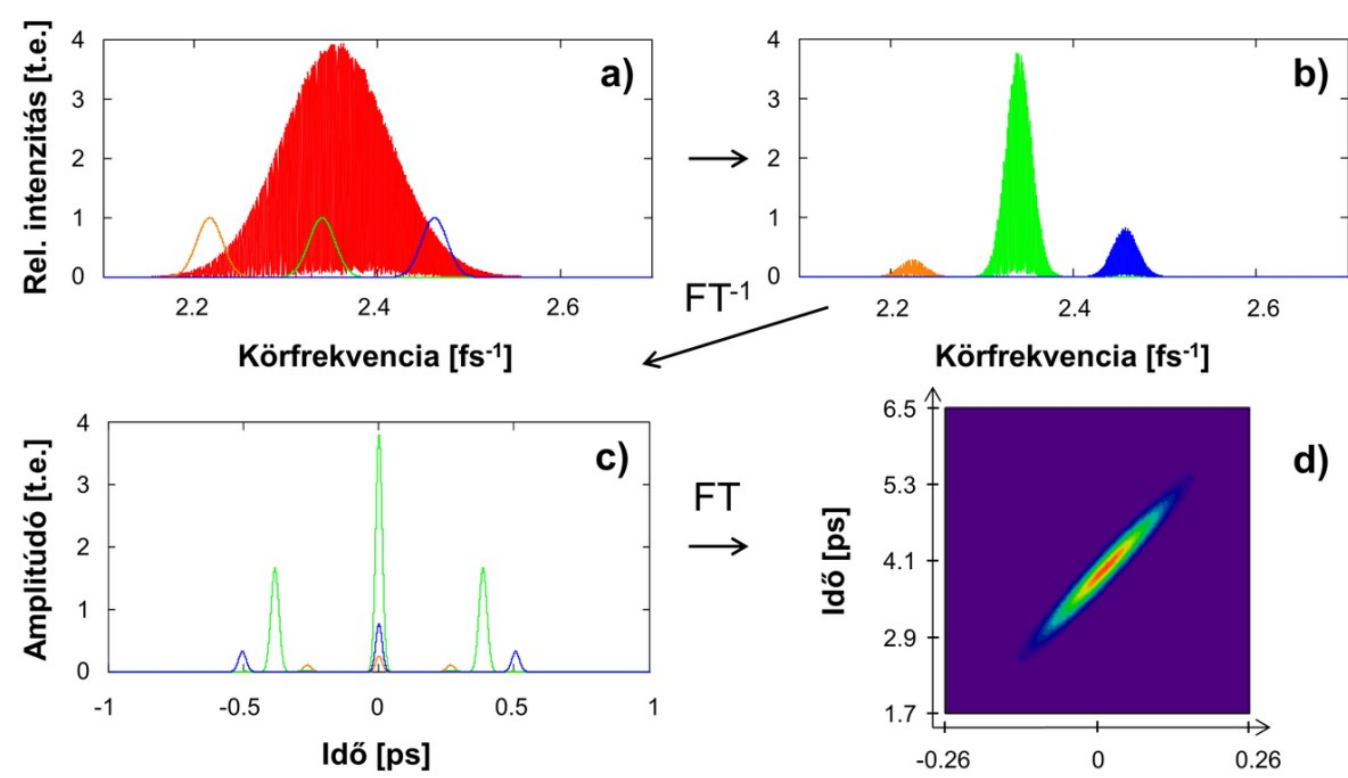

Rel. körfrekvencia [fs $\left.{ }^{-1}\right]$

2.18 ábra (a) Szimulált interferogram ablakfüggvényekkel. (b) Ablakolt interferogramok és (c) Fouriertranszformáltjaik. (d) A kapott ablakolt Fourier-transzformációs jel, melynek alakja megyezik a minta csoportkésleltetés-függvényével.

Az FT-módszernél leírtakhoz hasonlóan könnyen belátható, hogy $a(\omega)$ egy $\omega$-ban lassan változó függvény, így Fourier-transzformáltja a $t=0$ körül jelenik meg. Ezzel szemben $b(\omega)$, ami a minta diszperziójáról hordoz információt, egy $\omega$-ban gyorsan változó, valós függvény, melyet Fourier-transzformálva két jel áll elő, az ablakfüggvény központi frekvenciájától függő $\tau^{\prime}$ és a $-\tau^{\prime}$ késleltetéseknél $(2.18$ c) ábra $)$. Egy adott $\Omega$ körfrekvenciához tartozó $\tau^{\prime}$ és $-\tau^{\prime}$ jelpárból a $\tau^{\prime}$ késleltetéshez tartozó jelet kivágva a (2.28) összefüggés alapján adódik, hogy

$$
W_{f}(\Omega, t)=\int_{-\infty}^{\infty} \frac{b(\omega)}{2} g(\omega-\Omega) \exp [i \omega t-i \Phi(\omega)] d \omega .
$$

Fontos, hogy a $\Delta \Omega$-t úgy kell megválasztani, hogy két feltételnek is eleget tegyen: az $\Omega$ környezetében az interferenciacsíkok amplitúdója legyen állandó, azaz $b(\omega)=b(\Omega)$, valamint, hogy a fázis jó közelítéssel legyen lineáris, azaz 


$$
\Phi(\omega)=\Phi(\Omega)+\left.\frac{d \Phi}{d \omega}\right|_{\Omega}(\omega-\Omega) .
$$

Bevezetve a

$$
\begin{aligned}
& \xi=\omega-\Omega \\
& d \xi=d \omega
\end{aligned}
$$

jelöléseket, (2.29) átírható a következő formába:

$$
W_{f}(\Omega, t)=\frac{b(\Omega)}{2} \exp [-i(\Phi(\Omega)-\Omega t)] \int_{-\infty}^{\infty} g(\xi) \exp \left[\left(i\left(t-\Phi^{\prime}(\Omega)\right) \xi\right) d \xi\right]
$$

ahol $\Phi^{\prime}(\Omega)$ a spektrális fázis körfrekvencia szerinti első deriváltját jelöli. A (2.32) egyenletet átírva egy Gauss-burkolóval rendelkező jelet kapunk

$$
W_{f}(\Omega, t)=\frac{b(\Omega)}{2} \exp [-i(\Phi(\Omega)-\Omega t)] G\left[\left(t-\Phi^{\prime}(\Omega)\right)\right]
$$

ahol a jel ún. gerincvonala

$$
t_{p}(\Omega)=\Phi^{\prime}(\Omega)
$$

Vegyük észre, hogy a gerincvonalhoz tartozó $t_{p}$ időbeli késleltetések a minta csoportkésleltetését határozzák meg $(2.18$ d) ábra). Az SPP-módszernél látottakhoz hasonlóan itt is elmondható, hogy a késleltetés változtatásával, a $G D$-görbe is elmozdul az időtengely mentén, alakja azonban nem módosul, ezért a minta relatív csoportkésleltetése meghatározható. 


\section{CÉLKITŰZÉS}

Olyan mikrostruktúrált optikai szálak előállításánál, vagy optikai rendszerek beállításánál ahol a spektrális fázisban a $G D D$ értékének csökkentése a cél, a magasabb rendủ diszperziók hatásai válhatnak dominánsá. Tekintve, hogy a spektrális fázisfüggvény ekkor harmad- vagy annál magasabb rendü együtthatókat is tartalmazhat, a hagyományos üveglemezeknél vagy optikai szálaknál tapasztaltakkal ellentétben elméletileg akár több állandó fázisú pont is megjelenhet a spektrálisan bontott interferogramokon. Mivel az SPPk megfigyelésével ez esetben következtetni lehetne a magasabb rendü diszperziók domináns rendjére valamint azok előjelére is, lehetőség nyílna a diszperzió monitorozására akár valósidőben is. Dolgozatomban részletesen megvizsgálom a spektrális interferogramokon megjelenő SPP-k száma, mozgása, valamint alakja és a magasabb rendű diszperziós együtthatók közötti kapcsolatot. MathCad szoftver segítségével készített szimulációk felhasználásával demonstrálom, hogy különböző diszperziós rendek dominanciája milyen hatással van a kialakuló spektrális interferogram mintázatára.

Az SPP-módszer, mint magasabb rendü diszperzió monitorozásra szolgáló eljárás hatékonyságát és megbízhatóságát kísérletileg is érdemes tesztelni. Ehhez egy spektrálisan bontott Mach-Zehnder, valamint egy Michelson-interferométert építek, és meghatározom egy tömör magú Bragg-típusú mikrostruktúrált szál, valamint egy prizmapár diszperziós tulajdonságait az SPP-módszer segítségével.

Ahogyan azt az előző fejezetekben láthattuk, az optikai szálak diszperziója az SPPmódszeren kívül más, szintén spektrális interferometrián alapuló kiértékelési eljárásokkal is meghatározható. A különböző módszereket alkalmazó eddigi elméleti és kísérleti munkák esetében azonban nem történt meg ezen eljárások szisztematikus vizsgálata. Ahhoz, hogy rövid $(<1 \mathrm{~m})$ optikai szálak vizsgálatakor a lehető legmegfelelőbb módszert válasszuk, egy részletes összehasonlítás nagyon hasznos és hiánypótló lenne. Fontos továbbá megvizsgálni, hogy melyik módszer mennyire érzékeny a magasabb rendü diszperzió jelenlétére, illetve, hogy a vizsgált szál spektrumában esetlegesen megjelenő abszorpciós völgyek mennyire befolyásolják a kiértékelés pontosságát. Munkám során így célul tüzöm ki, hogy mikrostruktúrált szálak magasabb rendủ diszperziójának mérésekor pontosság szempontjából megvizsgálom és összehasonlítom az állandó fázisú pont, a minimum-maximum, a fázismodulált koszinuszillesztés, valamint a hagyományos és az 
ablakolt Fourier-transzformációs kiértékelési eljárásokat. Mintaként a korábban vizsgált Bragg-szálat választom, mely a transzmissziós spektrumában éles rezonanciákkal rendelkezik.

Tekintve, hogy a légmagos fotonikus szálak használata számos alkalmazás szempontjából előnyös, hasznos ilyen típusú szálak diszperziós jellemzőit is megvizsgálni. A HC-800 típusú optikai szálak hamar a figyelem középpontjába kerültek, több kutatócsoport is tanulmányozni kezdte őket. Ezen vizsgálatok főként a HC-800-01 PCF-re terjedtek ki, jelenleg azonban már csak a HC-800-02 típusú szál van kereskedelmi forgalomban. A HC-800-02 szál bizonyos tulajdonságait ugyan vizsgálták már, azonban csak a teljes müködési tartományához képest egy szük hullámhossztartományban. További munkám során ezért a HC-800-02 típusú optikai szál diszperziójának és polarizációjának vizsgálatát tüzöm ki célul a szál müködési tartományát tejesen lefedő 760-870 nm-es hullámhossztartományban. Méréseimhez a továbbiakban is a spektrális interferometriát, a kiértékeléshez pedig a hagyományos Fourier-transzformációs módszert használom. A diszperziót mindkét polarizációs irány mentén meghatározom. A szálakat használat közben gyakran feltekerik vagy meghajlítják, aminek következtében a szálban mechanikai feszültségek lépnek fel. Tekintve, hogy ilyen esetekben a szál kettőstörő és diszperziós tulajdonságai is megváltozhatnak, ezeket nem csupán a szál egyenes pozíciójában, hanem kissé belógatott, valamint feltekert helyzetében is megvizsgálom. A diszperziót, és ezáltal a szálgeometria uniformitását különböző, 10 és 97 cm közötti hosszúságú minták esetében is megvizsgálom.

A polarizációs módusdiszperzió jelenléte sok alkalmazás szempontjából hátrányos, így mérése nagy jelentőséggel bír. Az előzőekben vizsgált HC-800-02 PCF mindkét polarizációs módusának egyidejü gerjesztése mellett a PMD-t az FT-módszer segítségével indirekt és direkt módon is meghatározom, majd összehasonlítom a két megközelítés pontosságát.

Az előző fejezetben láthattuk, hogy az ablakolt Fourier-transzformáción alapuló kiértékelések eredményeképpen a minta csoportkésleltetése direkt módon adódik. Tekintve, hogy a $G D$-görbe alakjából a magasabb rendủ diszperziók dominanciájára valamint előjelére is következtetni lehet, érdemes a módszer alkalmazhatóságát más típusú optikai szálak esetén is megvizsgálni. Végezetül tehát azt tüzöm ki célul, hogy megvizsgálom, hogy a továbbfejlesztett, nagy frekvenciafeloldású WFR algoritmus 
alkalmazása milyen előnyökkel jár a korábban alkalmazott hagyományos FT-módszerhez képest. Mintaként ismét a HC-800-02 PCF szolgál. 


\section{EREDMÉNYEK}

A 4.1 fejezetben a célkitüzésnek megfelelően megvizsgálom az SPP-k és a magasabb rendủ diszperziók kapcsolatát szimulációk valamint mikrostruktúrált Braggszállal és egy prizmapárral végzett mérés segítségével. A 4.2 fejezetben a korábban ismertetett öt, spektrális interferometrián alapuló kiértékelési eljárás pontosságát hasonlítom össze a mikrostruktúrált Bragg-szál esetében. Az eredményeket bemutató utolsó három fejezetben (4.3-4.5) egy HC-800-02 típusú PCF polarizációfüggő diszperziós tulajdonságait vizsgálom meg a hagyományos és az ablakolt Fourier-transzformációs módszerek alkalmazásával.

\subsection{Az állandó fázisú pontok és a magasabb rendü diszperzió kapcsolatának vizsgálata}

\subsubsection{Szimulációs vizsgálatok}

Szimulációkat készítettem MathCad 14 szoftver segítségével annak bemutatására, hogy adott diszperziós együtthatók miként befolyásolják a megjelenő SPP-k számát, mozgását illetve alakját. A domináns, pozitív $G D D$ esete jól ismert, tekintve, hogy az üveglemezek és a lencsék ehhez hasonló diszperziós tulajdonságokkal rendelkeznek. Ha a spektrális fázisban a domináns tag a pozitív másodrendủ diszperzió, a $G D$ értéke mindössze egy frekvenciaértéknél veszi fel a zéró értéket, azaz egyetlen SPP alakul ki az interferogramon, ami a nagyobb frekvenciaértékek felé halad, ahogy a referenciakar hossza növekszik. Negatív $G D D$ esetén az SPP viszont a kisebb frekvenciaértékek felé halad a referenciakar hosszának növekedésével, ahogyan azt a 2.3.1.1 fejezetben láttuk.

Sok alkalmazás szempontjából kerülendő, hogy a céltárgyra érkező impulzus időben kiszélesedjen, ezért a másodrendű diszperzió kompenzálására nagy hangsúlyt fektetnek. Tekintve, hogy ez prizma-, rács- vagy grism párokkal, illetve speciálisan tervezett optikai szálakkal elérhető, rendszerint a magasabb rendü diszperziók növekedésének árán, a továbbiakban megvizsgálom ezen magasabb rendü fázisderiváltak hatásait az SPP-k számára, mozgására és alakjára.

Elsőként a domináns $T O D\left(\omega_{0}\right)$ esetét tekintem át, ahol a minta spektrális fázisfüggvényének Taylor-sorában a $G D D\left(\omega_{0}\right), F O D\left(\omega_{0}\right)$, és a további magasabb rendü 
deriváltakat nullának veszem. Ekkor az interferométer két karja között mérhető fáziskülönbség és a csoportkésleltetés-függvény a (2.5) és a (2.10) összefüggéseket felhasználva az alábbi alakban adható meg:

$$
\begin{gathered}
\Phi(\omega)=\varphi_{m}\left(\omega_{0}\right)+G D_{m}\left(\omega_{0}\right) \Delta \omega+\frac{T O D\left(\omega_{0}\right)}{6} \Delta \omega^{3}+\tau \omega . \\
G D(\omega)=G D_{m}\left(\omega_{0}\right)+\frac{T O D\left(\omega_{0}\right)}{2} \Delta \omega^{2}+\tau .
\end{gathered}
$$

A $T O D\left(\omega_{0}\right)$ értéke a szimuláció során először $100000 \mathrm{fs}^{3}$ volt, ami nagyságrendileg egy olyan rácspár harmadrendủ diszperziójának felel meg, melyben a rácsok karcolatszáma $600 \mathrm{vonal} / \mathrm{mm}$ és egymástól $30 \mathrm{~cm}$-re helyezkednek el. Tekintve, hogy a későbbiekben a mérésekhez 700-900 nm-es hullámhossztartományon müködő fényforrást és detektort használok, a szimulációk során is ezen tartományban végeztem vizsgálataimat. Az alkalmazott központi hullámhossz $800 \mathrm{~nm}$ volt. A szimulációval elöállított interferogram a hozzá tartozó fázisgörbével és csoportkésleltetés-görbével a 4.1 a)-c) ábrákon látható, ahol a $\varphi_{m}\left(\omega_{0}\right)$-t és a $\tau$-t nullának választottam, a $G D_{m}\left(\omega_{0}\right)$ pedig -250 fs volt.

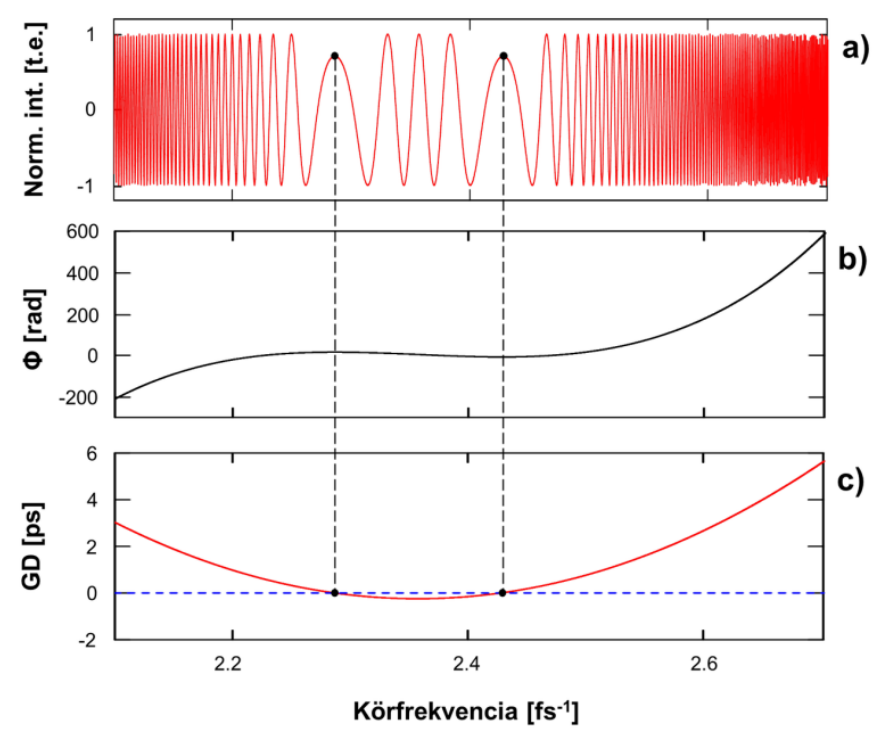

4.1 ábra (a) Szimulált normált interferogram $\varphi_{m}\left(\omega_{0}\right)=0, G D_{m}\left(\omega_{0}\right)=-250 \mathrm{fs}, \operatorname{TOD}\left(\omega_{0}\right)=100000 \mathrm{fs}^{3}$ $G D D\left(\omega_{0}\right)=F O D\left(\omega_{0}\right)=Q O D\left(\omega_{0}\right)=0$ és $\tau=0$ esetén. A relatív csoportkésleltetés 2.285 és $2.427 \mathrm{fs}^{-1}$ körfrekvencia értékeknél veszi fel a 0 ps értéket. (b) Spektrális fázisgöbe és (c) relatív csoportkésleltetésgörbe.

A $T O D$ jelenléte miatt a spektrális fázisgörbe harmadfokú, azaz a minta $G D$ függvénye másodfokú, a $G D$ így két frekvenciaértéknél veszi fel a zéró értéket. Ekkor a 
(2.16) egyenletnek bizonyos $\tau$ értékeknél két megoldása lesz, következésképpen pedig két SPP alakul ki az interferogramon [113], melyek közül mindkettőt monitorozni kell ahhoz, hogy pontos információt kapjunk a vizsgált minta diszperziójáról. Fontos kiemelni, hogy ez nem a PMD [85] vagy a módusdiszperzió [89], hanem a TOD következménye.

Ahhoz, hogy az SPP-módszert használva megfelelő GD-görbét megkapjuk, mindkét SPP mozgását követnünk kell. Ehhez további interferogramokat szimuláltam különbözö késleltetések megadásával. A 4.2 ábrán jól látszik, hogy a két SPP szimmetrikusan távolodik egymástól a referenciakar hosszának növelésével. Ezen felismerés, illetve a kirajzolódó $G D$-görbe alakja is mind a pozitív TOD jelenlétére utal.

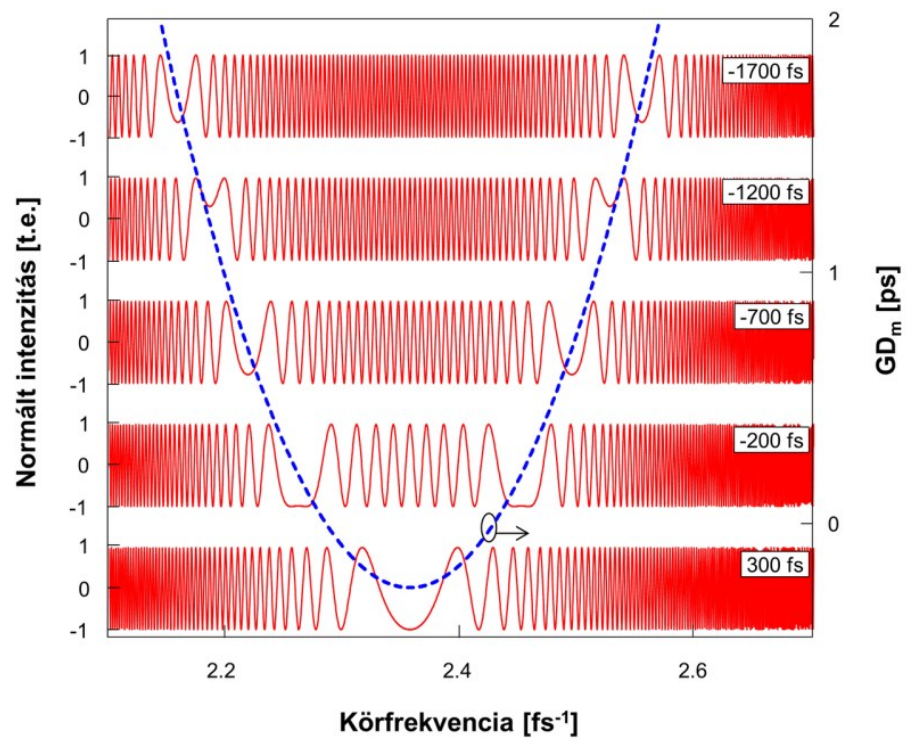

4.2 ábra Szimulált normált interferogramok $\varphi_{m}\left(\omega_{0}\right)=0, G D_{m}\left(\omega_{0}\right)=-250 \mathrm{fs}, T O D\left(\omega_{0}\right)=100000 \mathrm{fs}^{3}$

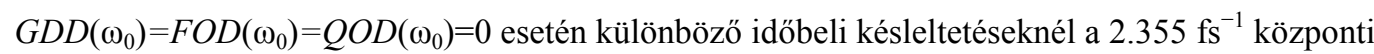
frekvenciára vonatkoztatott együtthatókkal, a minta másodrendü csoportkésleltetés-görbéjével (kék szaggatott) együtt ábrázolva. A referenciakar hossza lentről felfelé növekszik.

Ahogyan az a 4.2 ábrán megfigyelhető, ilyen nagyságrendü diszperzióknál bizonyos késleltetések esetében az interferogram csíkrendszere már jelentősen besürüsödik. Tekintve, hogy a spektrométer felbontóképessége véges, a vizibilitás ilyenkor lecsökken, megnehezítve ezáltal a kiértékelést a legtöbb rendelkezésre álló módszerrel. Mivel azonban az SPP-k környezetében a csíkrendszer kiritkul, és így spektrális helyzetük meghatározható, az SPP-k megfigyelésén alapuló kiértékelési eljárás ilyen esetekben is alkalmazható. 
Mivel prizma vagy grism párok segítségével [114] előállítható negatív TOD is, a következőkben ennek hatásait vizsgálom meg szimulációk segítségével. A 4.3 ábrán jól látható, hogy a $\varphi_{m}\left(\omega_{0}\right)=0$, a $G D_{m}\left(\omega_{0}\right)=400$ fs és a $T O D\left(\omega_{0}\right)=-100000 \mathrm{fs}^{3}$-ra történö állításával a GD-függvény konvexből konkávba fordul, illetve ez esetben az SPP-k egymáshoz közeledtek a referenciakar hosszának növelésével.

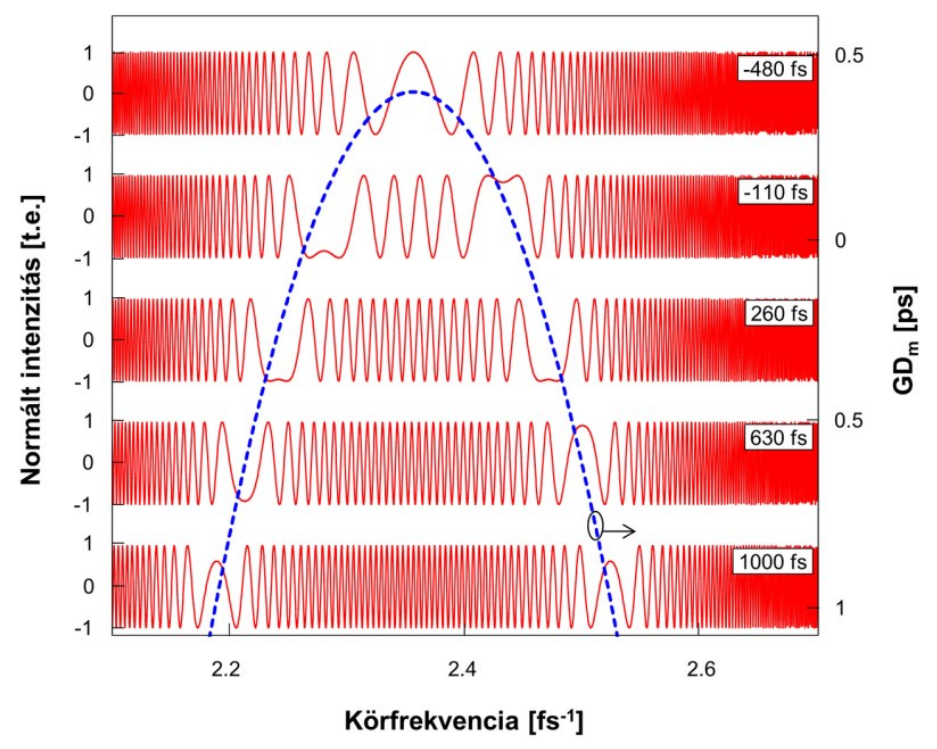

4.3 ábra Szimulált normált interferogramok $\varphi_{m}\left(\omega_{0}\right)=0, G D_{m}\left(\omega_{0}\right)=400 \mathrm{fs}, T O D\left(\omega_{0}\right)=-100000 \mathrm{fs}^{3}$ $G D D\left(\omega_{0}\right)=F O D\left(\omega_{0}\right)=Q O D\left(\omega_{0}\right)=0$ esetén különböző időbeli késleltetéseknél a $2.355 \mathrm{fs}^{-1}$ központi frekvenciára vonatkoztatott együtthatókkal, a minta másodrendü csoportkésleltetés-görbéjével (kék szaggatott) együtt ábrázolva. A referenciakar hossza lentről felfelé növekszik.

Habár a hagyományos üvegek $F O D$-járuléka jó közelítéssel elhanyagolható, prizmapárok, rácspárok, valamint mikrostruktúrált szálak esetében azonban ennek hatásaival is számolni kell, így ezen tag hatását is megvizsgáltam. Tekintve, hogy a prizma- és rácspárok negatív $F O D$-t állítanak elő, a szimulációkhoz is negatív értéket, $-500000 \mathrm{fs}{ }^{4}$-t választottam, a $\varphi_{m}\left(\omega_{0}\right)$ és $G D_{m}\left(\omega_{0}\right)$ pedig 0 fs volt. Ez az érték egy olyan rácspár negyedrendü diszperziójával egyezik meg, melyben a rácsok karcolatszáma 600 vonal/mm és egymástól $60 \mathrm{~cm}$-re helyezkednek el.

Első ránézésre (4.4 ábra) ez az eset meglehetősen hasonlít a negatív $G D D$ esetére, bár ahogyan az a 4.4 c) és 4.5 ábrákról látszik, a $G D$-függvény itt nem lineáris, hanem harmadrendü. Ilyen paraméterek mellett ugyan szintén egy SPP alakul ki az inteferogramokon, azonban ez néhány késleltetés esetén olyannyira kiszélesedik, hogy lehetetlen meghatározni a pontos helyét, ezáltal pedig a diszperziót megmérni az SPP- 
módszer segítségével. Az interferenciacsíkok sürüsödése itt is megfigyelhető, különösképpen a nagyobb körfrekvenciák tartományában.

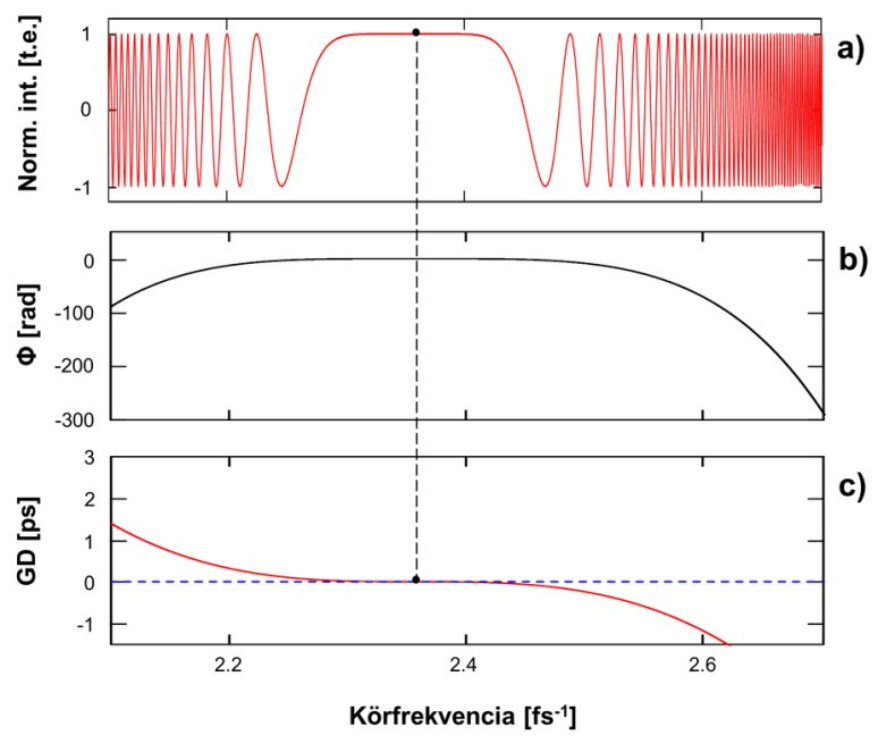

4.4 ábra (a) Szimulált normált interferogram $\varphi_{m}\left(\omega_{0}\right)=0, G D_{m}\left(\omega_{0}\right)=0 \mathrm{fs}, F O D=-500000 \mathrm{fs}^{4}$ $G D D\left(\omega_{0}\right)=T O D\left(\omega_{0}\right)=Q O D\left(\omega_{0}\right)=0$ és $\tau=0$ esetén. A relatív csoportkésleltetés $2.355 \mathrm{fs}^{-1}$ körfrekvencia értékeknél veszi fel a 0 ps értéket. (b) Spektrális fázisgöbe és (c) relatív csoportkésleltetés-görbe.

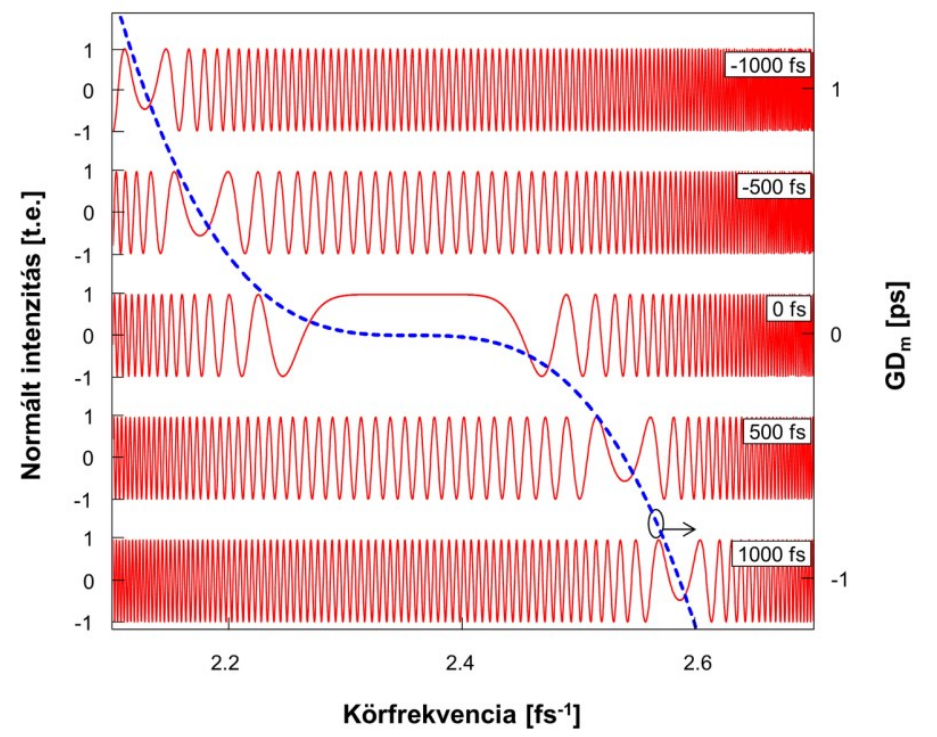

4.5 ábra Szimulált normált interferogramok $\varphi_{m}\left(\omega_{0}\right)=0, G D_{m}\left(\omega_{0}\right)=0 \mathrm{fs}, F O D=-500000 \mathrm{fs}^{4}$ $G D D\left(\omega_{0}\right)=T O D\left(\omega_{0}\right)=Q O D\left(\omega_{0}\right)=0$ esetén különböző időbeli késleltetéseknél a $2.355 \mathrm{fs}^{-1}$ központi frekvenciára vonatkoztatott együtthatókkal, a minta harmadrendű csoportkésleltetés-görbéjével (kék szaggatott) együtt ábrázolva. A referenciakar hossza lentről felfelé növekszik.

Az eddigi eredményeket összefoglalva elmondható, hogy az SPP-módszer mindaddig alkalmas a diszperzió meghatározására, amíg a $G D D$ vagy a $T O D$ a domináns rend a vizsgált optikai elem spektrális fázisában, viszont pontatlan lesz, ha az $F O D$ válik a 
meghatározó diszperziós együtthatóvá. Az eddig vizsgált esetekben az SPP-k számából és alakjából következtetni lehet a domináns diszperzió rendjére, mozgásából pedig az előjel is megállapítható.

További szimulációk segítségével megvizsgáltam, hogy lehetséges-e kettőnél több SPP kialakulása. Különböző diszperziók beállításával megfigyeltem, hogy a páros rendü diszperziós együtthatók kombinált hatása bizonyos késleltetéseknél három SPP kialakulását eredményezi (4.6 a) ábra). A gyakorlatban ez egy olyan esetnek felel meg, amikor a $T O D$ teljes mértékben kompenzálva van, például egy impulzusnyújtóban vagy kompresszorban, viszont maradék diszperzió $G D D$ és $F O D$ formájában még jelen van. A szimulációk során ehhez hasonló eredményt értem el, amikor a $\varphi_{m}\left(\omega_{0}\right)=0, G D_{m}\left(\omega_{0}\right)$ értéke $100 \mathrm{fs}$, a $G D D\left(\omega_{0}\right) 3000 \mathrm{fs}^{2}$, az $F O D\left(\omega_{0}\right)$ pedig $-500000 \mathrm{fs}^{4}$ volt, a többi koefficiens viszont zérus volt. Egy így előállított interferogram a hozzá tartozó fázisgörbével és csoportkésleltetés-görbével a 4.6 a)-c) ábrasorozaton látható.

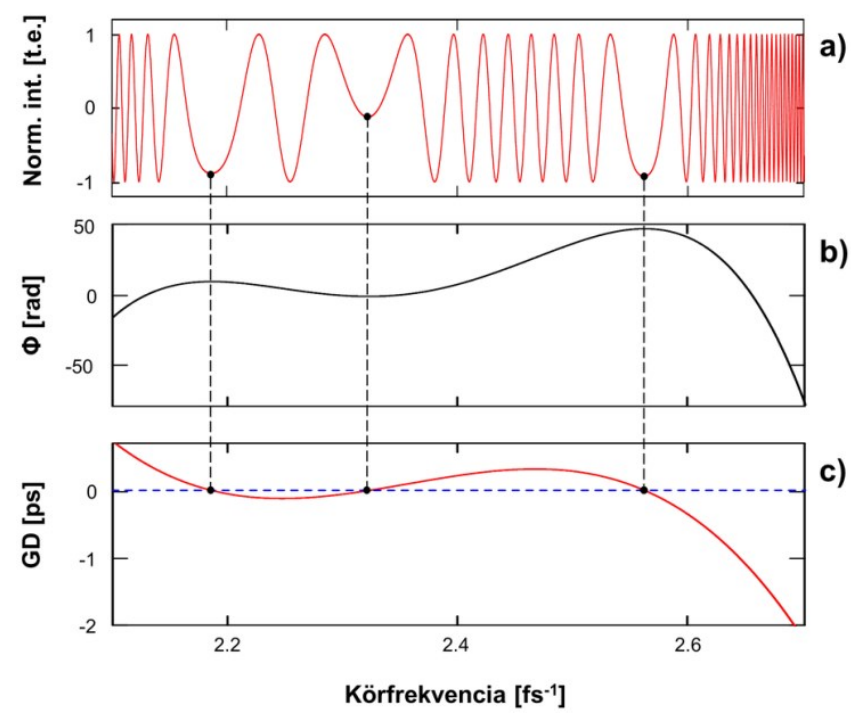

4.6 ábra (a) Szimulált normált interferogram $\varphi_{m}\left(\omega_{0}\right)=0, G D_{m}\left(\omega_{0}\right)=100 \mathrm{fs}, G D D\left(\omega_{0}\right)=3000 \mathrm{fs}^{2}$, $F O D\left(\omega_{0}\right)=-500000 \mathrm{fs}^{4}, T O D\left(\omega_{0}\right)=Q O D\left(\omega_{0}\right)=0$ és $\tau=0$ esetén. A relatív csoportkésleltetés $2.186,2.322$ és

$2.561 \mathrm{fs}^{-1}$ körfrekvencia értékeknél veszi fel a 0 ps értéket. (b) Spektrális fázisgöbe és (c) relatív csoportkésleltetés-görbe.

A 4.7 ábráról jól látszik, hogy ilyen paraméterek mellett bizonyos késleltetéseknél nem három, hanem kettő SPP alakul ki. Ahogy a relatív időbeli késleltetés csökkent, azaz a referenciakar hossza nőtt, a kisebb körfrekvenciáknál megjelenő SPP kettévált, és az újonnan kialakult SPP közeledni kezdett a kezdetben nagyobb frekvenciáknál látható SPP felé, majd egyesült azzal. Ezzel egyidőben a másik új SPP pedig a kisebb frekvenciák felé 
mozdult el. Megállapítottam, hogy a domináns FOD esetéhez képest itt az SPP-k helye már pontosan meghatározható, következésképpen a módszer alkalmas ilyen típusú diszperziók meghatározására is.

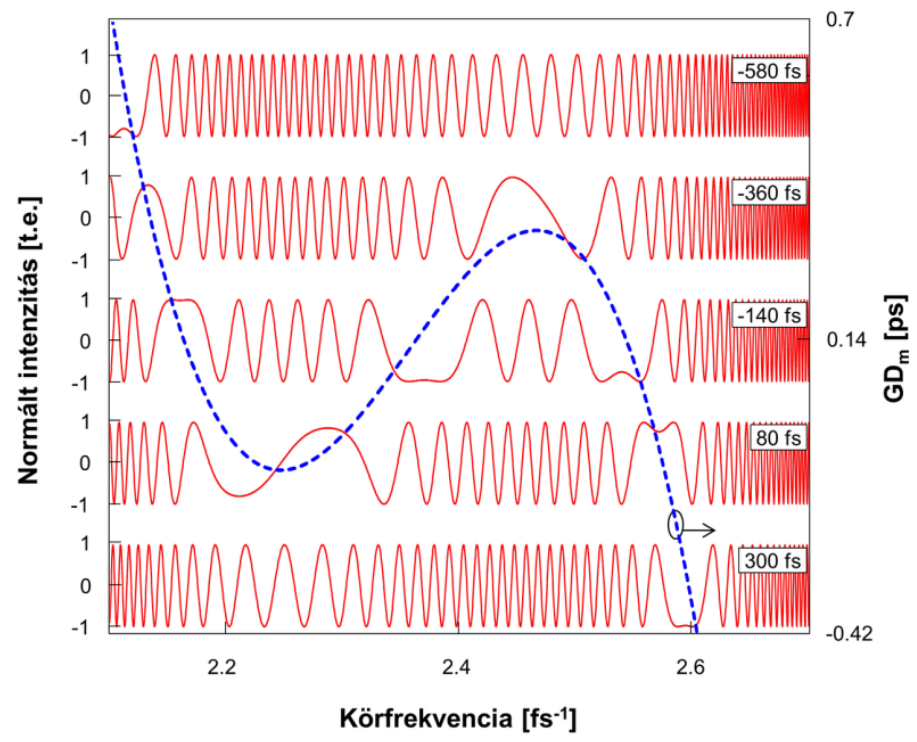

4.7 ábra Szimulált normált interferogramok $\varphi_{m}\left(\omega_{0}\right)=0, G D_{m}\left(\omega_{0}\right)=100 \mathrm{fs}, G D D\left(\omega_{0}\right)=3000 \mathrm{fs}^{2}$, $F O D\left(\omega_{0}\right)=-500000 \mathrm{fs}^{4}, T O D\left(\omega_{0}\right)=Q O D\left(\omega_{0}\right)=0$ esetén különböző időbeli késleltetéseknél a $2.355 \mathrm{fs}^{-1}$ központi frekvenciára vonatkoztatott együtthatókkal, a minta csoportkésleltetés-görbéjével (kék szaggatott) együtt ábrázolva. A referenciakar hossza lentről felfelé növekszik.

A páros rendekhez hasonlóan, a kombinált páratlan rendek összhatását is megvizsgáltam további szimulációk segítségével. Néhány késleltetés esetén itt már akár négy SPP is kialakulhat (4.8 a) ábra). A szimulációban a $\varphi_{m}\left(\omega_{0}\right)=0, G D_{m}\left(\omega_{0}\right)=0$ fs, $\operatorname{TOD}\left(\omega_{0}\right)=-50000 \mathrm{fs}^{3}, Q O D\left(\omega_{0}\right)=10^{7} \mathrm{fs}^{5}$ értékeket használtam, a többi diszperziós együtthatót pedig nullára állítottam. Habár a $Q O D$ a legtöbb esetben nem ilyen számottevő, ahogy azt a későbbi fejezetekben látni fogjuk, mikrostruktúrált optikai szálak rendelkezhetnek hasonló nagyságrendü ötödrendủ diszperzióval. A szimulációval előállított interferogram a hozzá tartozó fázisgörbével és csoportkésleltetés-görbével a 4.8 a)-c) ábrákon látható. 


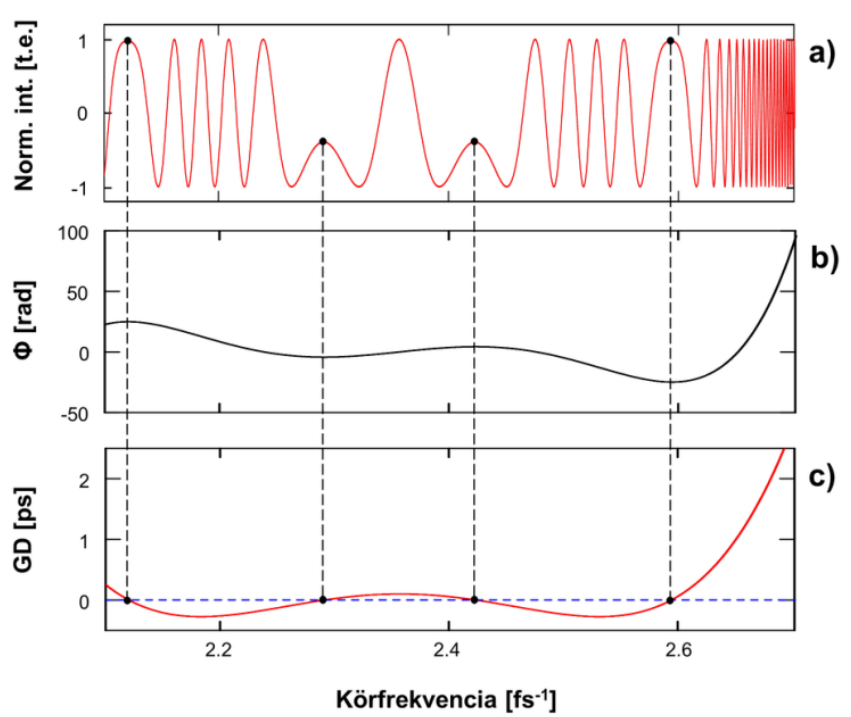

4.8 ábra (a) Szimulált normált interferogram $\varphi_{m}\left(\omega_{0}\right)=0, G D_{m}\left(\omega_{0}\right)=100 \mathrm{fs}, T O D\left(\omega_{0}\right)=-50000 \mathrm{fs}^{3}$, $Q O D\left(\omega_{0}\right)=10^{7} \mathrm{fs}^{5} G D D\left(\omega_{0}\right)=F O D\left(\omega_{0}\right)=0$ és $\tau=0$ esetén. A relatív csoportkésleltetés $2.186,2.322$ és $2.561 \mathrm{fs}^{-1}$ körfrekvencia értékeknél veszi fel a 0 ps értéket. (b) Spektrális fázisgöbe és (c) relatív csoportkésleltetésgörbe.

Ahogy a korábbi esetekben is, ábrázolva az egymást követő késleltetések beállításával kapott interferogramokat a $G D$-görbe alakja kirajzolódik (4.9 ábra).

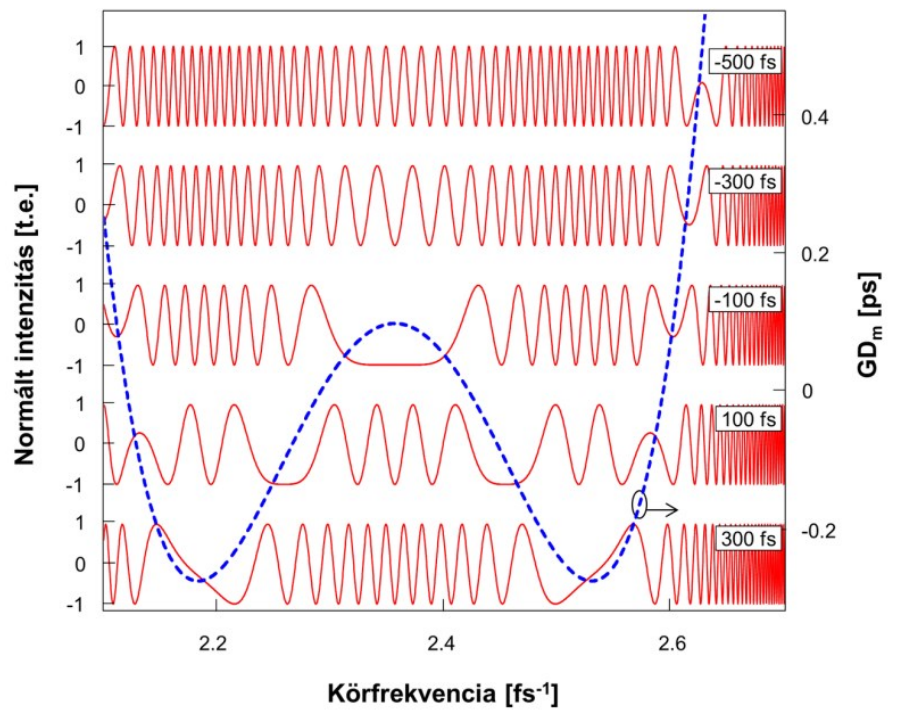

4.9 ábra Szimulált normált interferogramok $\varphi_{m}\left(\omega_{0}\right)=0, G D_{m}\left(\omega_{0}\right)=100 \mathrm{fs}, T O D\left(\omega_{0}\right)=-50000 \mathrm{fs}^{3}$, $Q O D\left(\omega_{0}\right)=10^{7} \mathrm{fs}^{5}, G D D\left(\omega_{0}\right)=F O D\left(\omega_{0}\right)=0$ esetén különböző relatív időbeli késleltetéseknél a $2.355 \mathrm{fs}^{-1}$ központi frekvenciára vonatkoztatott együtthatókkal, a minta csoportkésleltetés-görbéjével (kék szaggatott) együtt ábrázolva. A referenciakar hossza alulról felfelé növekszik.

Habár néhány késleltetésnél kettő vagy három SPP is kialakulhat, ez az eset megkülönböztethető az előző, kombinált $G D D$ és $F O D$ esetétől, ugyanis itt a késleltetés 
csökkenésével két SPP válik ketté, melyek közül a két középső elindul egymás felé, mindaddig, míg nem egyesülnek. Eközben a két szélső SPP távolodik a referenciakar növelésével. Ehhez hasonló szimmetria nem volt megfigyelhető a páros rendek kombinált dominanciája esetén.

Általánosságban véve elmondható, hogy az SPP-k számából, mozgásából és alakjából lehetséges megjósolni, hogy mely diszperziós rendek dominánsak. Továbbá, ezáltal a diszperzió monitorozható, ami igen előnyös lehet például nyújtó-kompresszor párok optimalizálásakor. Ahhoz, hogy minden kétséget kizáróan megkapjuk melyik rend a domináns, mindenképp érdemes meghatározni a koefficienseket a $G D$-görbére történő megfelelő fokszámú polinomillesztés elvégzésével. Az SPP-módszer alkalmasnak mondható mikrostruktúrált optikai szálak esetén tapasztalható magasabb rendü diszperziók kimutatására is.

\subsubsection{Kíséreti ellenőrzés}

A következőkben a 4.1.1 szakaszban bemutatott szimulációk eredményeit szeretném kísérleti eredményekkel összehasonlítani. Elsőként egy $30.2 \mathrm{~cm}$ hosszúságú, Bragg-típusú, üvegmagú, PBG vezetés elvén működő optikai szál diszperzióját vizsgálom meg spektrális interferometriával. A szál részletes bemutatása a 2.1.4.1 fejezetben olvasható. Fényforrásként egy szélessávú titán-zafír (Ti:S) lézer oszcillátort használtam (Femtolasers, Rainbow, impulzushossz: 6 fs, központi hullámhossz: 800 nm, FWHM = $150 \mathrm{~nm}$ ), míg az interferométer egyik kimenetén detektorként egy nagyfelbontású spektrométer (Ocean Optics HR4000, 700-900 nm, spektrális felbontás: $0.2 \mathrm{~nm}$ ) szolgált. $\mathrm{Az}$ interferométer másik kimenetéhez egy $\mathrm{CCD}$ kamerát helyeztem a becsatolás minőségének ellenőrzéséhez. A megépített Mach-Zehnder típusú interferométer a 4.10 ábrán látható. A szaggatott vonallal jelölt rész a referenciakar állítható részét jelöli. A szálat az interferométer tárgykarjába helyeztem el. A becsatoláshoz egy mikroszkóp objektívet $(\mathrm{NA}=0.25,10 \mathrm{x})$, a szál kimenetének kollimálásához pedig egy $19 \mathrm{~mm}$ fókusztávolságú akromát lencsét használtam. 


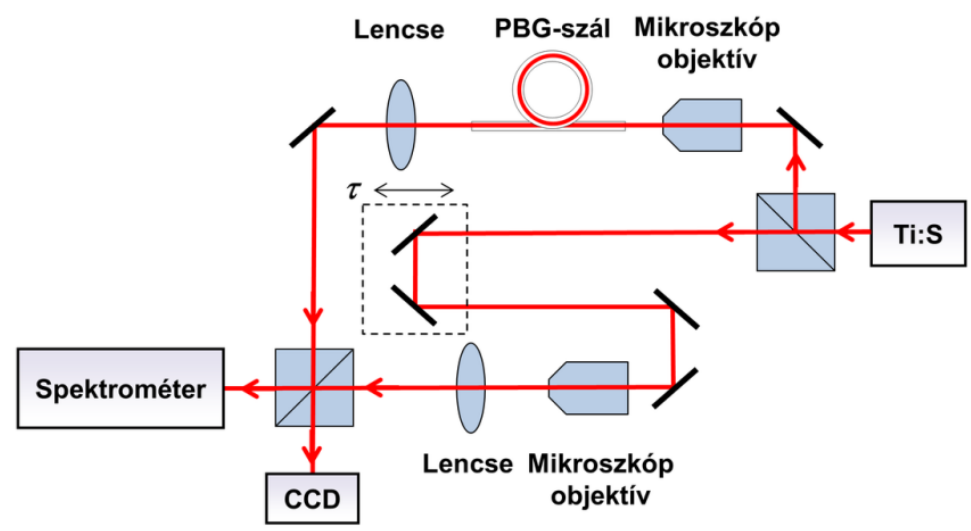

4.10 ábra Spektrálisan bontott Mach-Zehnder interferométer a Bragg-típusú mikrostruktúrált optikai szál diszperziójának meghatározására.

A becsatoló és kollimáló lencséket a referenciakarba is behelyeztem azért, hogy azok diszperziója kompenzálásra kerüljön. Ekkor a kapott interferogram teljes mértékben a vizsgált szál diszperziója miatt kialakuló mintázatot mutatja. A 4.11 ábrán különböző késleltetésekél felvett normált interferogramok láthatók. Megfigyelhető, hogy néhány interferogram esetén a csíkrendszer besürüsödik és a láthatóság a spektrométer véges felbontóképessége miatt jelentősen lecsökken. Ahogyan azt a szimulációknál már láthattuk, az SPP-k környezetében a csíkrendszer kiritkul, így ezek pozíciója kellő pontossággal meghatározható. Néhány késleltetésnél megfigyelhető, hogy két SPP jelenik meg az interferogramon, amiből a szimulációknál látottak alapján a pozitív TOD jelenlétére lehet következtetni (4.1 ás 4.2 ábrák).

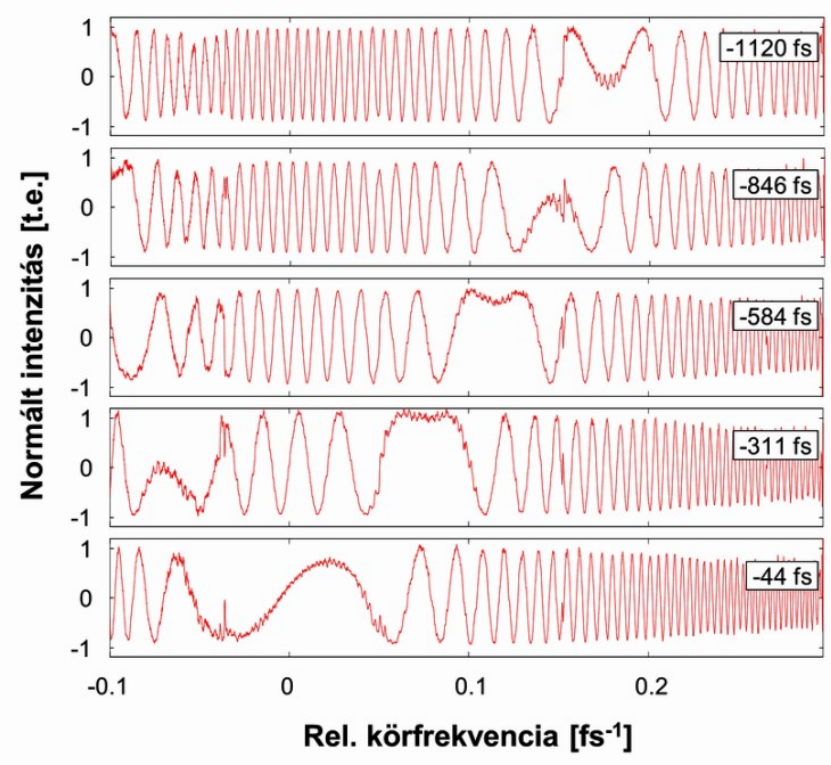

4.11 ábra A Bragg-szál esetén felvett normált interferogramok különböző relatív csoportkésleltetéseknél. A referenciakar hossza lentről felfelé növekszik. 
A felvett interferogramok SPP-módszerrel történő kiértékelése után kapott $G D$ görbe a 4.12 ábrán látható. Erre egy negyedfokú polinomot illesztettem, mert ebben az esetben volt minimális az eltérés a mért és az illesztett görbe között. A diszperziós koefficienseket így ötödrendig határoztam meg (1. Táblázat).

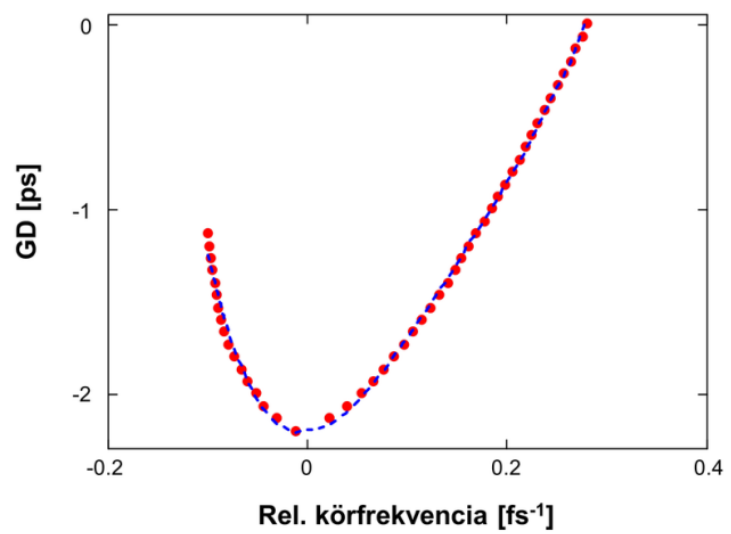

4.12 ábra A Bragg-szál esetén az állandó fázisú pont módszerével meghatározott csoportkésleltetés-görbe (piros pontok) és a ráillesztett negyedfokú polinom (kék szaggatott).

Ha a kapott fázisderiváltakat összehasonlítjuk egy a szállal megegyező hosszúságú ömlesztett kvarctömb esetében [57] kapott, az 1. Táblázatban szintén látható együtthatókkal, jól látszik, hogy a vizsgált Bragg-szál $G D D$-je körülbelül két nagyságrenddel kisebb, TOD-ja pedig ugyanennyivel nagyobb. Habár az FOD és a $Q O D$ esetében is jelentős növekedés tapasztalható, ezeknek az SPP-kre gyakorolt hatása nem volt annyira jelentős, mint a TOD esetében, melynek dominanciáját a két SPP megjelenése is alátámasztja. A méréssel kapott $G D$-görbét (4.12 ábra) összehasonlítva a szimulációk során kapottal (4.2 ábra) szintén jó egyezés látszik.

Ahhoz, hogy a szimulációk eredményét további mérések eredményeivel is össze tudjam vetni, más típusú speciális optikai szálak hiányában a következő méréseknél egy ömlesztett kvarcból készült prizmapár diszperzióját vizsgáltam meg. A prizmák egymáshoz viszonyított pozíciójának manipulálásával könnyen elő tudtam állítani több különböző esetet is. Ehhez a 4.13 ábrán látható Michelson-interferométeres elrendezést építettem meg. Fényforrásként egy $100 \mathrm{~W}$-os halogén lámpa fényét használtam, melynek kollimálásához egy 50 és egy 150 mm fókusztávolságú lencsére volt szükség. A prizmákat az interferométer tárgykarjába helyeztem $40 \mathrm{~cm}$ távolságra egymástól. A használt prizmák törőszöge $67.5^{\circ}$ volt. A mérések megkezdése elött egy csapótükör, egy $300 \mathrm{~mm}$ fókusztávolságú lencse és egy periszkóp segítségével egy spektrográfba (CEOptics, CEO- 
2D-800-V, 700-900 nm, spektrális felbontás: $0.15 \mathrm{~nm}$ ) vezettem a nyalábokat, annak ellenőrzésére, hogy a rendszer szögdiszperziómentes. A referenciakar végtükrének mozgatásával különböző karhosszakat állítottam be, és a vizsgálható spektrális tartomány megnövelésének céljából egy kisebb felbontású spektrométert (Avantes 3648, 200-1100 nm, spektrális felbontás: $1 \mathrm{~nm}$ ) használtam az interferogramok felvételéhez.

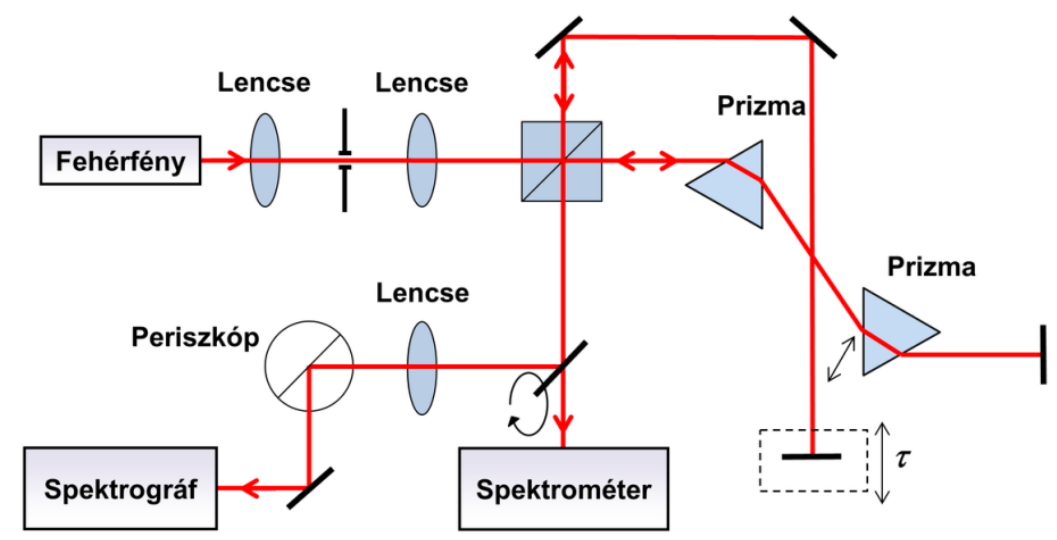

4.13 ábra Spektrálisan bontott Michelson-interferométer a prizmapár diszperziójának meghatározására.

A mérések során nem csak a referenciakar hossza, hanem a második prizmában megtett optikai úthossz, azaz a rendszer diszperziója is változtatható volt. Az első mérés során a prizma anyagában megtett úthosszat minimálisra állítottam $(3.5 \mathrm{~mm})$, melynek eredményeképpen egy SPP alakult ki az interferogramon, ami a kisebb frekvenciák felé haladt a referenciakar hosszának növelésével (4.14 a) ábra), negatív $G D D$ dominanciára utalva. Ez szemléletesen azt jelenti, hogy az első prizma által bevezetett szögdiszperzió okozta negatív $G D D$ meghaladja a prizmában való terjedés során fellépő anyagi diszperzió pozitív $G D D$-jét. Ahogy a prizma fényútba való betolásával nőtt az üvegben megtett úthossz (6.25 mm), domináns TOD-ra jellemző viselkedést mutatva két SPP jelent meg néhány késleltetésnél $(4.14$ b) ábra). A prizma anyagában megtett úthosszat tovább növelve $(12 \mathrm{~mm})$ ismét egy SPP jelent meg, ami a referenciakar hosszának növelésével ez esetben már a nagyobb frekvenciák felé mozdult el (4.14 c) ábra), domináns pozitív GDD jelenlétét sugallva. Habár a láthatóság ez utóbbi esetben jelentősen lecsökkent, az SPP-k pozíciója továbbra is meghatározható volt. 
a)

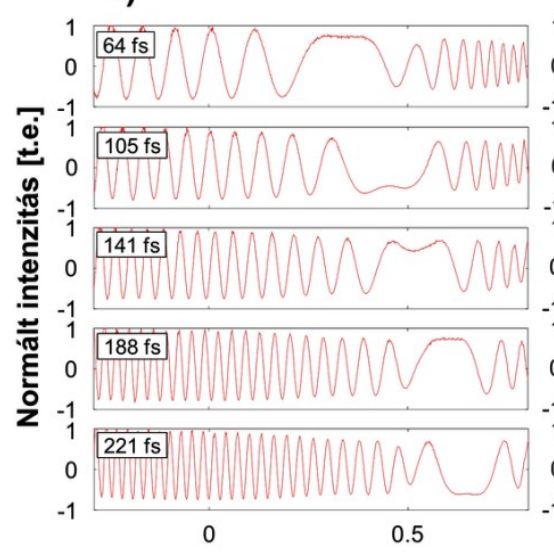

b)

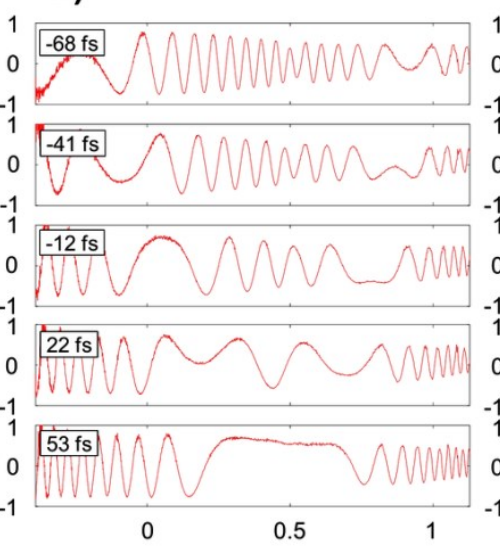

Rel. körfrekvencia [fs $\left.{ }^{-1}\right]$ c)

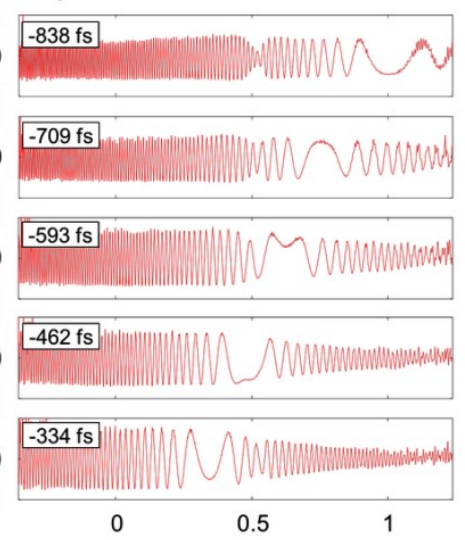

4.14 ábra A prizmapár esetén a második prizma különböző pozícióiban felvett normált interferogramok különböző relatív csoportkésleltetéseknél. A referenciakar hossza lentröl felfelé növekszik, míg a relatív időbeli késleltetés csökken.

A felvett interferogramok SPP-módszerrel történő kiértékelése után meghatároztam a $G D$-görbéket, melyekre harmadfokú polinomot illesztve megkaptam a diszperziós együtthatókat negyedrendig (4.15 ábra és 1. Táblázat). Jól látszik, hogy a minimális üvegben való áthaladás esetében a $G D D$ valóban domináns és negatív, ahogyan az az SPPk megfigyelésével is megjósolható (4.14 a) ábra). Hasonlóan, a maximális üvegben megtett út esete is megfelel a várakozásoknak, ugyanis ez esetben a $G D D$ domináns és pozitív, nagyságával pedig összeegyeztethető az interferencia csíkok korábban megfigyelt besürüsödése (4.14 c) ábra).
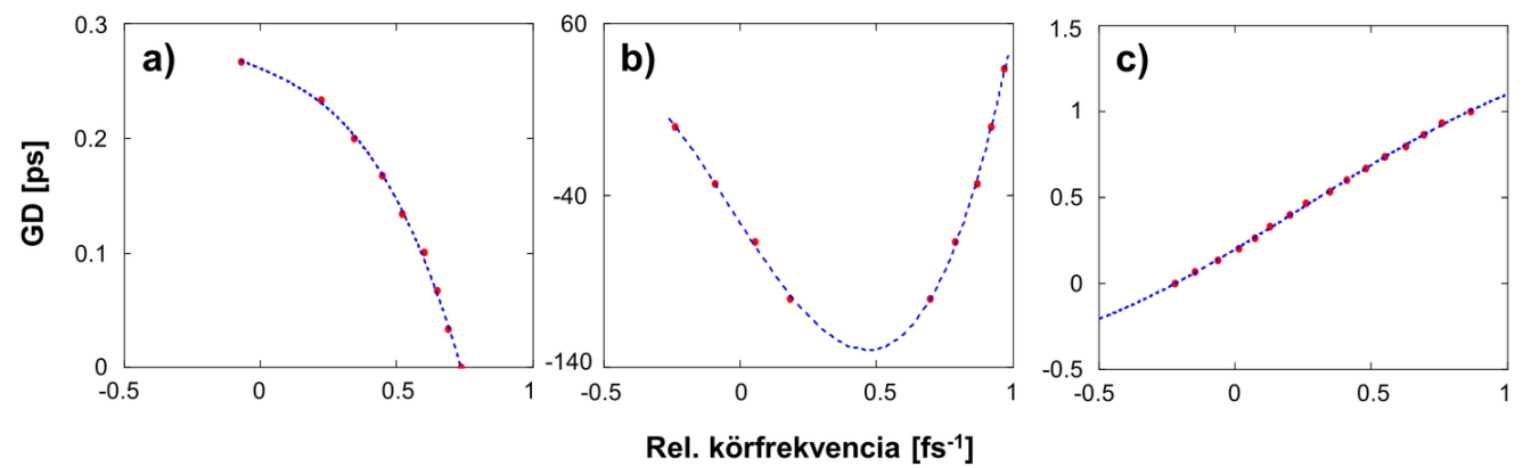

4.15 ábra A prizmapár esetén az állandó fázisú pont módszerével meghatározott (piros pontok) és illesztett (kék szaggatott) relatív csoportkésleltetés a körfrekvencia függvényében a második prizma különböző pozícióiban: (a) minimális $(3.5 \mathrm{~mm})$, (b) növekvő $(6.25 \mathrm{~mm})$ és (c) maximális (12 $\mathrm{mm})$ üvegben megtett úthossz esetén. 
A közbülső esetben (4.14 b) ábra) azonban, amikor a prizma anyagában megtett úthosszat kissé megnöveltem, a kiértékelés azt mutatja, hogy a TOD értéke igen csekély, tehát ez nem okozhatja a két SPP megjelenését.

1. táblázat A $30.2 \mathrm{~cm}$ hosszúságú Bragg-szál, megegyező hosszúságú ömlesztett kvarchasáb és a $67.5^{\circ}$ törőszögü, egymástól $40 \mathrm{~cm}$ távolságra elhelyezett ömlesztett kvarc prizmákból álló prizmapár diszperziós együtthatói a minimális $^{\mathrm{a}}(3.5 \mathrm{~mm})$, növekvöb $^{\mathrm{b}}(6.25 \mathrm{~mm})$ és maximális $^{\mathrm{c}}(12 \mathrm{~mm})$ üvegben megtett úthossz esetén.

\begin{tabular}{ccccc}
\hline & $G D D\left[\mathrm{fs}^{2}\right]$ & $T O D\left[\mathrm{fs}^{3}\right]$ & $F O D\left[\mathrm{fs}^{4}\right]$ & $Q O D\left[\mathrm{fs}^{5}\right]$ \\
\hline Bragg szál & $697 \pm 36$ & $1.39 \cdot 10^{5} \pm 360$ & $-1.75 \cdot 10^{6} \pm$ & $1.17 \cdot 10^{7} \pm$ \\
Ömlesztett & $1.09 \cdot 10^{4}$ & $8.3 \cdot 10^{3}$ & $-3.45 \cdot 10^{3}$ & $9.59 \cdot 10^{3}$ \\
kvarchasáb & & & & \\
Prizma pár & $-100 \pm 2$ & $-80 \pm 26$ & $-1.918 \cdot 10^{\mathrm{a}} \pm 23$ & $/$ \\
Prizma pár $^{\mathrm{b}}$ & $245 \pm 9$ & $342 \pm 45$ & $-1.323 \cdot 10^{3} \pm 105$ & $/$ \\
Prizma pár & $950 \pm 6$ & & & $/$ \\
\hline
\end{tabular}

Ahogyan azt a szimulációk is mutatták, a páros rendek kombinált hatása is eredményezheti két SPP kialakulását (4.7 ábra) néhány késleltetésnél rövid hullámhossztartományban vizsgálva. Mivel hasonló effektus, azaz a két SPP megjelenése megfigyelhető a páratlan rendek kombinációja esetében is bizonyos késleltetéseknél (4.8 ábra), a kapott GD-görbére illesztettem egy negyedfokú polinomot is, hogy az együtthatókat egészen a $Q O D$-ig meghatározzam. A kiértékelés során jól látszott, hogy a $Q O D$ bevezetése szükségtelen, ugyanis ekkor nagy szórással adódott a többi koefficiens is, így egyértelműen levonható az a következtetés, miszerint esetünkben nem a kombinált $T O D$ és $Q O D$, hanem a kombinált $G D D$ és $F O D$ okozta a két SPP megjelenését. Fontos kiemelni, hogy a viszonylag kis diszperziós együtthatók miatt ez az eset nagy hasonlóságot mutatott a TOD-domináns esethez is, mert a vizsgált spektrális tartomány a szükségesnél kisebb volt, és nem követte le az SPP-k mozgását. Ilyen esetekben célszerü a vizsgált spektrális tartomány kibővítésével, vagy a diszperziós koefficiensek meghatározásával kizárni az bizonytalanságokat.

Összefoglalva tehát elmondható, hogy mivel egynél több SPP megjelenése egyértelműen magasabb rendủ diszperzió jelenlétére utal, elmondható, hogy olyan 
esetekben, amikor ez is elegendő információ - például prizmapárok, nyújtó-kompresszor rendszerek beállításánál - az SPP-k megfigyelése igen jó módszer.

Az elvégzett kísérletek alapján levont következtetések hasznosak lehetnek speciális, tervezhető optikai tulajdonságokkal rendelkező mikrostruktúrált szálakat jellemző magasabb rendủ diszperziók mérésekor, illetve ezen szálak további fejlesztésében és a gyártás utáni minőség leellenőrzésében. Továbbá, az SPP-k számának, mozgásának és alakjának megfigyelése lehetőséget nyújt a maradék diszperzió kvázi valós idejü monitorozására, ami sok esetben, például nyújtó-kompresszor rendszerek beállításakor igen hasznos lehet.

\subsubsection{A fejezethez kapcsolódó tézispont}

T1. Különböző diszperziós rendek interferenciamintázatra gyakorolt hatását vizsgáltam meg MathCad 14 szoftverben készített szimulációk segítségével. Megmutattam, hogy az állandó fázisú pontok számát, mozgását és alakját analizálva következtetni lehet adott magasabb rendủ diszperzió dominanciájára. Domináns harmadrend kettő, kombinált másod- és negyedrend három, valamint kombinált harmad- és ötödrend négy állandó fázisú pont megjelenését eredményezte. Megállapítottam, hogy az állandó fázisú pontok pozíciói minden esetben nagy pontossággal meghatározhatók, kivéve a domináns negyedrend esetében, amikor is az állandó fázisú pont kis késleltetések esetében túlságosan kiszélesedik, ami a mérési pontosságot jellemzően zavarja. Az állandó fázisú pontok és a magasabb rendủ diszperziók kapcsolatát kísérletileg egy $30 \mathrm{~cm}$ hosszúságú Bragg-típusú optikai szál, valamint egy változtatható diszperzióval rendelkező ömlesztett kvarcból készült, $60^{\circ}$-os törőszögü prizmapár esetében is megvizsgáltam. A Bragg-szálon végzett mérések eredményei egyeztek a szimulációknál tapasztaltakkal, prizmapár esetében azonban a vizsgált spektrális tartomány túl szük volt ahhoz, hogy lekövesse az állandó fázisú pontok teljes mozgását, így a monitorozás ellentmondásos eredményre vezetett. Megállapítottam, hogy teljes bizonyossággal csak a koefficiensek méréssel történő meghatározásával mondható meg, hogy melyik diszperziós rend a domináns [115]. 


\subsection{Spektrális interferogramok kiértékelési módszereinek összehasonlítása}

Az alábbiakban a 2.1.4.1 fejezetben bemutatott, ezúttal $37 \mathrm{~cm}$ hosszúságú, nagy móduskeresztmetszetü, üvegmagú Bragg-szál diszperzióját vizsgálom meg és ennek során összehasonlítom különböző, spektrális interferometrián alapuló kiértékelési eljárások pontosságát.

A szál diszperziójának meghatározására szolgáló kísérleti elrendezés egy MachZehnder interferométerből és egy nagyfelbontású spektrométerből (Ocean Optics HR4000, 700-900 nm, spektrális felbontás: $0.2 \mathrm{~nm}$ ) állt (4.16 ábra). Szélessávú fényforrásként egy Ti:S oszcillátor szolgált (impulzushossz: 20 fs, központi hullámhossz: $800 \mathrm{~nm}, \mathrm{FWHM}=$ $60 \mathrm{~nm}$ ). A lézerfény becsatolása egy mikroszkóp objektív (NA $=0.5,25 \mathrm{x})$ segítségével történt, míg kimenet kollimálására egy $18 \mathrm{~mm}$-es fókusztávolságú akromát lencse segítségével történt. Az ábrán szaggatott vonallal jelölt rész a referenciakar mozgatható részét, azaz a késleltető elemet mutatja. A tárgykarba szürők kerültek elhelyezésre, hogy az intenzitások minél inkább kiegyenlítettek legyenek a két karban. Mivel a szál csekély kettőstörést mutatott, egy polarizátort helyeztem a spektrométer elé, az interferenciacsíkok láthatóságának feljavítására.

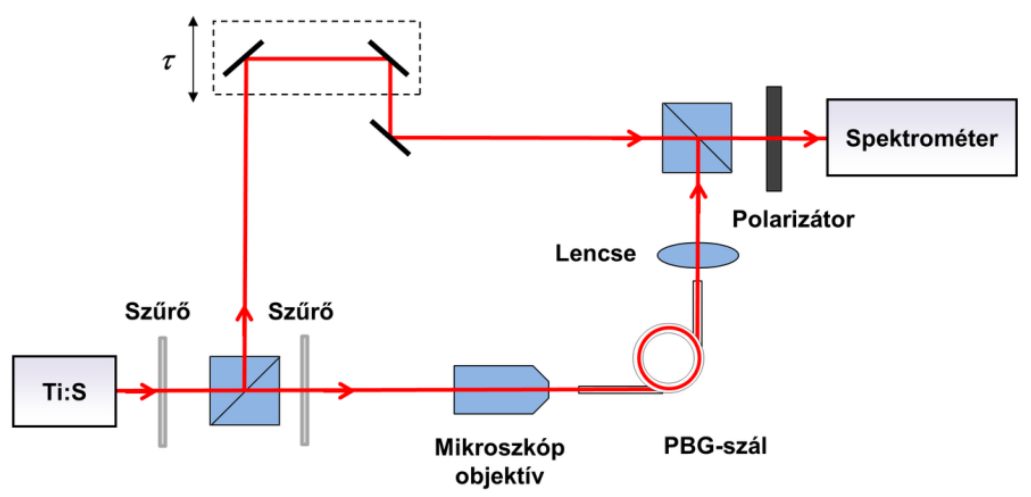

4.16 ábra Spektrálisan bontott Mach-Zehnder interferométer a Bragg-típusú optikai szál diszperziójának meghatározására.

Különböző késleltetések beállításával interferogramokat vettem fel, majd értékeltem ki a korábban ismertetett módszerek alkalmazásával. Bizonyos késleltetések esetén két SPP figyelhető meg a kiértékelési tartományon (4.17 ábra), ami, ahogy azt az előző fejezetben is láthattuk, domináns TOD jelenlétére utal [113]. Ahogyan arra korábban is utalás történt, a magasabb rendű diszperziók ilyen speciális szálak esetén sokkal nagyobb jelentőséggel bírnak, mint ahogy azt a hagyományos optikai szálak esetén 
megszokhattuk, ezért a deriváltakat elöször negyed-, majd ötödrendig határoztam meg, megfigyelve mely esetben kapok pontosabb eredményt. Tekintve, hogy a mérendő szál spektrumában abszorpciós völgyek megjelenésére lehet számítani, megvizsgálom, hogy ilyen esetekben a Taylor-koefficiensek meghatározásán, illetve polinomillesztésen alapuló kiértékelési módszerek mennyire alkalmasak a diszperzió leírására.

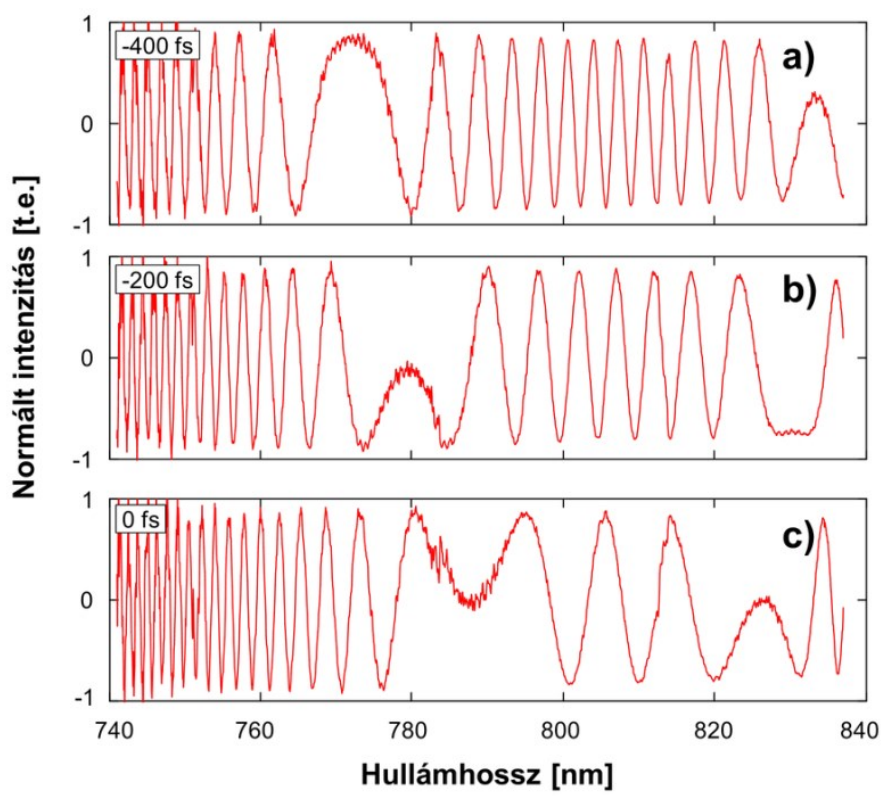

4.17 ábra A 37 cm hosszú Bragg-szállal felvett normált interferogramok különböző időbeli késleltetésnél.

\subsubsection{Kiértékelés állandó fázisú pont módszerének alkalmazásával}

Elsőként az SPP-módszert használtam a Bragg-szál csoportkésleltetésének meghatározására. Az SPP-k pozícióit 24 interferogram felhasználásával 740 és $840 \mathrm{~nm}$ között határoztam meg kb. 4 nm-enként, amelyek a tárgy- és a referenciakar -1600 és 0 fs közötti időbeli késleltetés beállításával kerültek rögzítésre. Megjegyzendő, hogy a negatív késleltetési érték ebben az esetben azt jelenti, hogy a referenciakar hossza meghaladta a tárgykarét. Ahhoz, hogy a diszperziós együtthatókat negyedrendig meghatározzam, egy harmadfokú polinomot illesztettem az SPP-k által meghatározott GD-görbére. Ahogyan az a 4.18 a) ábráról is látható, az eltérés a mért és az illesztett görbe között jelentős, általában \pm 20 fs között ingadozik, de eléri \pm 30 fs-ot is. A következő lépésben az illesztés negyedfokú polinom segítségével történt, a diszperziós koefficienseket pedig ötödrendig határoztam meg (2. táblázat). A 4.18 b) ábráról jól látható, hogy a két görbe közötti eltérés csökkent (tipikusan \pm 10 fs), ami valóban ötödrendü diszperzió jelenlétére utal. A szálspektrumot megfigyelve látható egy éles levágás 838 nm-nél, aminek köszönhetően a 
használt Ti:S lézer biztosította egyébként szélesebb kiértékelési tartomány lerövidül, illetve 783 és 813 nm-nél abszorpciós völgyeket fedezhetünk fel (4.18 c) ábra). Habár az SPP-k mozgására kihatással vannak ezen rezonanciák, az alacsony hullámhosszfelbontás (4 $\mathrm{nm})$ nem teszi lehetővé a spektrális fázisban emiatt megjelenő csúcsoknál fellépő $G D$ ugrások pontos detektálását. A kapott $G D$-görbe a 4.18 d) ábrán látható. Tekintve, hogy a negyedfokú polinom illesztése vezetett pontosabb eredményre, a 4.18 d) ábrán csak ez kerül bemutatásra.

Annak ellenére, hogy az illesztés szemmel láthatóan pontosabb a negyedfokú polinom esetén, elmondható, hogy az SPP-módszer 1 m-nél rövidebb szálak esetében nem elég pontos, különösen a szivárgó módusok környezetében.
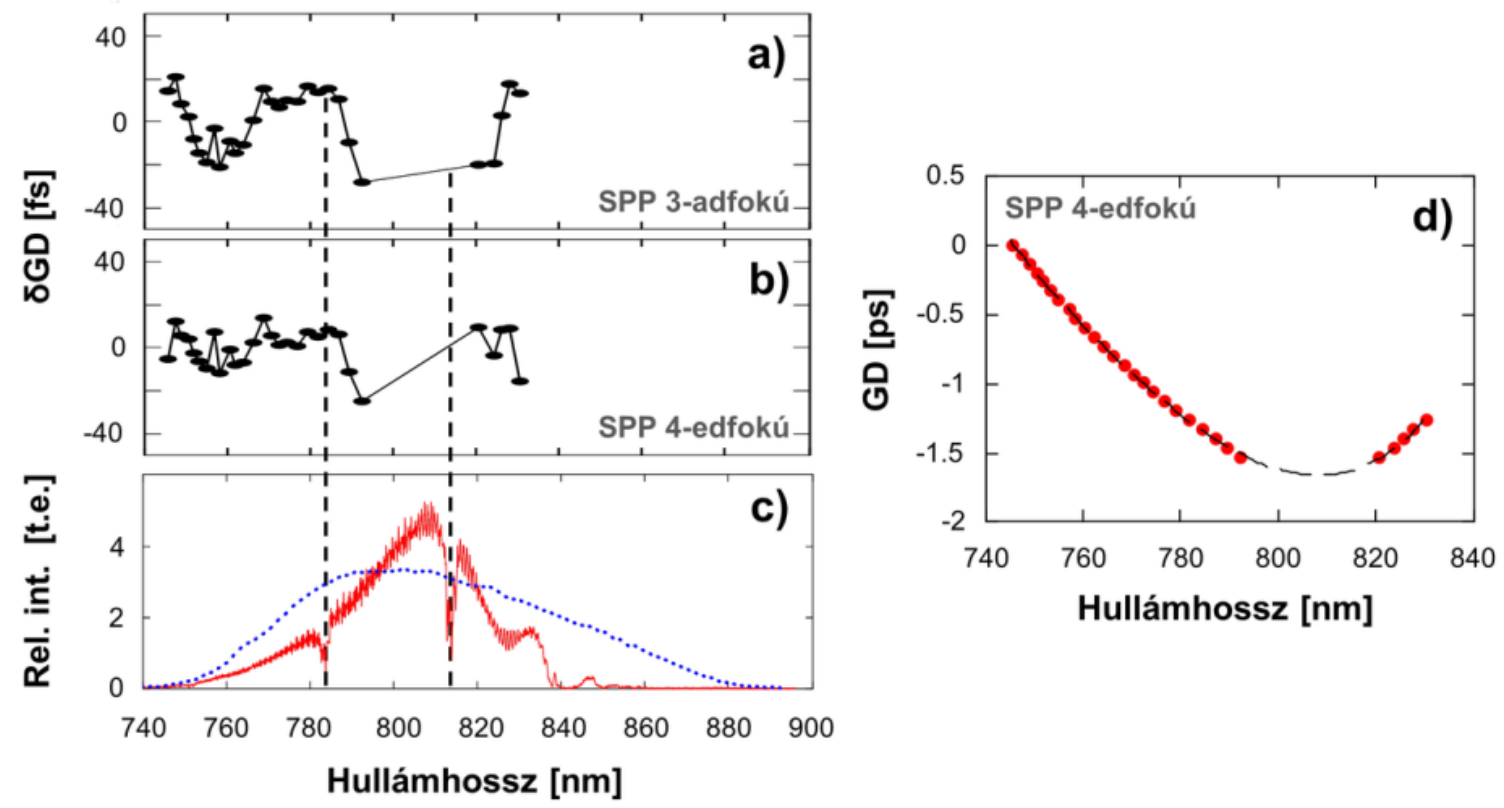

4.18 ábra A mért és az illesztett csoportkésleltetés-görbe közötti eltérés (a) harmadfokú és (b) negyedfokú polinom illesztése esetén az állandó fázisú pont módszerét alkalmazva. (c) A tárgykar (piros) és a Ti:S lézer (kék pontozott) spektruma. A szivárgó módusokhoz tartozó hullámhosszakat szaggatott vonalak jelölik. (d) Az állandó fázisú pont módszerének segítségével meghatározott (piros) és illesztett (fekete szaggatott) relatív csoportkésleltetés a hullámhossz függvényében.

\subsubsection{Kiértékelés a minimum-maximum módszer alkalmazásával}

A diszperziós együtthatókat meghatároztam további 30 interferogram felhasználásával, melyek esetén az intenzitás-minimumok és -maximumokhoz tartozó körfrekvenciaértékeket olvastam le. A kiértékelési tartomány ebben az esetben némileg 
hosszabb volt, tekintve, hogy az interferogramokon az SPP megjelenése nem volt feltétel. A spektrális fázis ez esetben így -1700 és 240 fs közötti relatív késleltetés beállításával került meghatározásra. Negyedfokú polinom illesztése, azaz negyedrendű diszperzió feltételezése esetén a mért és az illesztett fázisgörbe eltérése a 4.19 a) ábrán látható. A fázisgörbére ötödfokú polinomot illesztve viszont a két görbe közötti elérés jelentősen lecsökken (4.19 b) ábra). A mért spektrális fázisgörbe a ráillesztett ötödfokú polinommal a 4.19 c) ábrán látszik, a kapott diszperziós együtthatók pedig a 2. táblázatban láthatók.

Figyelembe véve, hogy az illesztett polinom fokszámától függetlenül is igen jelentős eltérés tapasztalható a mért és az illesztett görbék között, összességében elmondható, hogy a MM-módszer kevéssé alkalmas magasabb rendü diszperzió pontos meghatározására, vagy a spektrumban jelenlevő fázisugrások kimutatására.

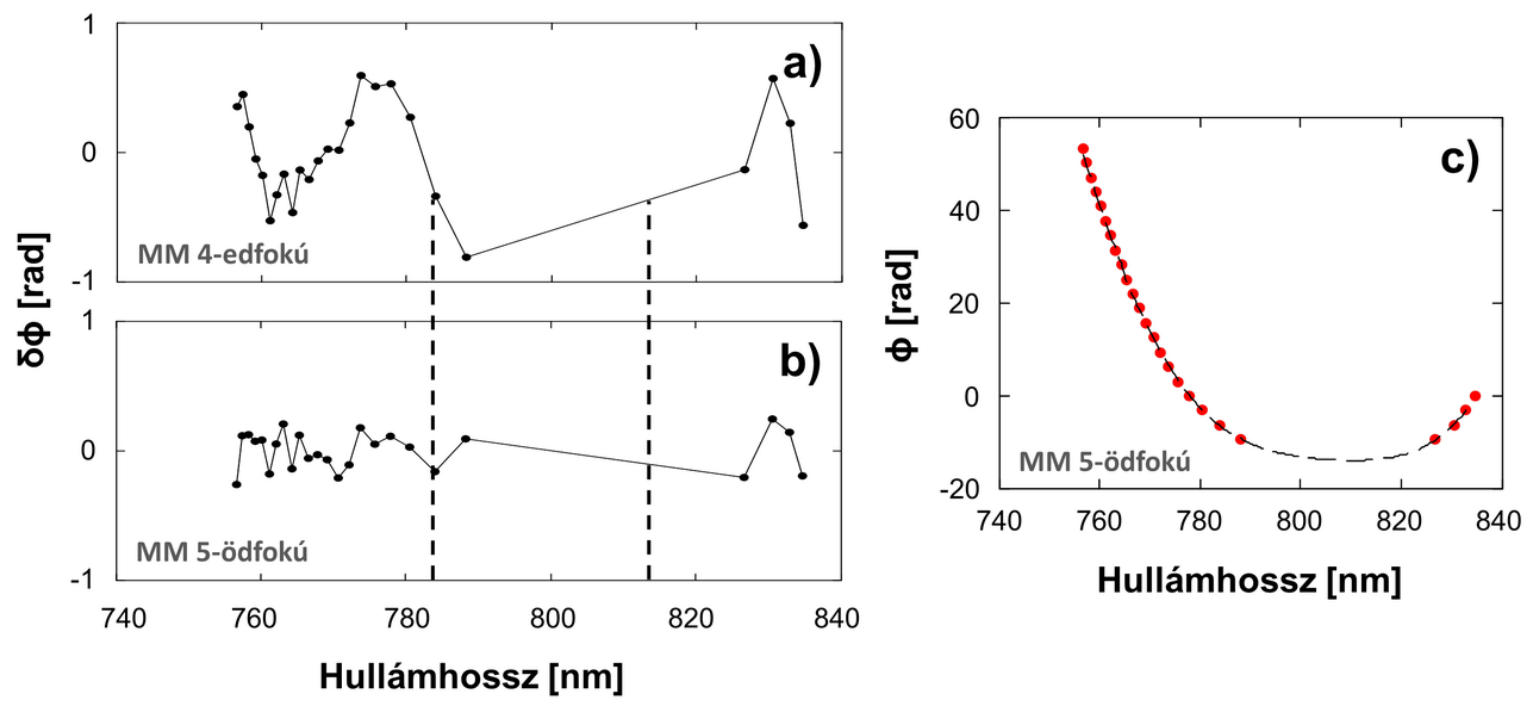

4.19 ábra A mért és az illesztett fázisgörbe közötti eltérés (a) negyedfokú és (b) ötödfokú polinom illesztése esetén a minimum-maximum módszert alkalmazva. A szivárgó módusokhoz tartozó hullámhosszakat szaggatott vonalak jelölik. (c) A minimum-maximum módszer segítségével meghatározott (piros pontok) és illesztett (fekete szaggatott) spektrális fázis a hullámhossz függvényében.

\subsubsection{Kiértékelés fázismodulált koszinusz-függvény illesztésével}

Azon 30 interferogramot, melyek az előzőekben MM-módszerrel kiértékelésre kerültek, CFF-módszerrel is kiértékeltem ugyanezen késleltetés tartományon belül. Először egy olyan koszinusz-függvényt illesztettem a normált interferogramra, melynek fázisában negyedfokú polinom volt. A 4.20 a) ábráról jól látható, hogy a két görbe illeszkedése nem tökéletes föképp a hosszabb hullámhosszaknál megjelenő SPP esetén. A koszinusz- 
függvény argumentumába ötödfokú polinomot írva az illeszkedés jelentősen javul (4.20 b) ábra). Az így kapott diszperziós együtthatók a 2. táblázatban láthatók.

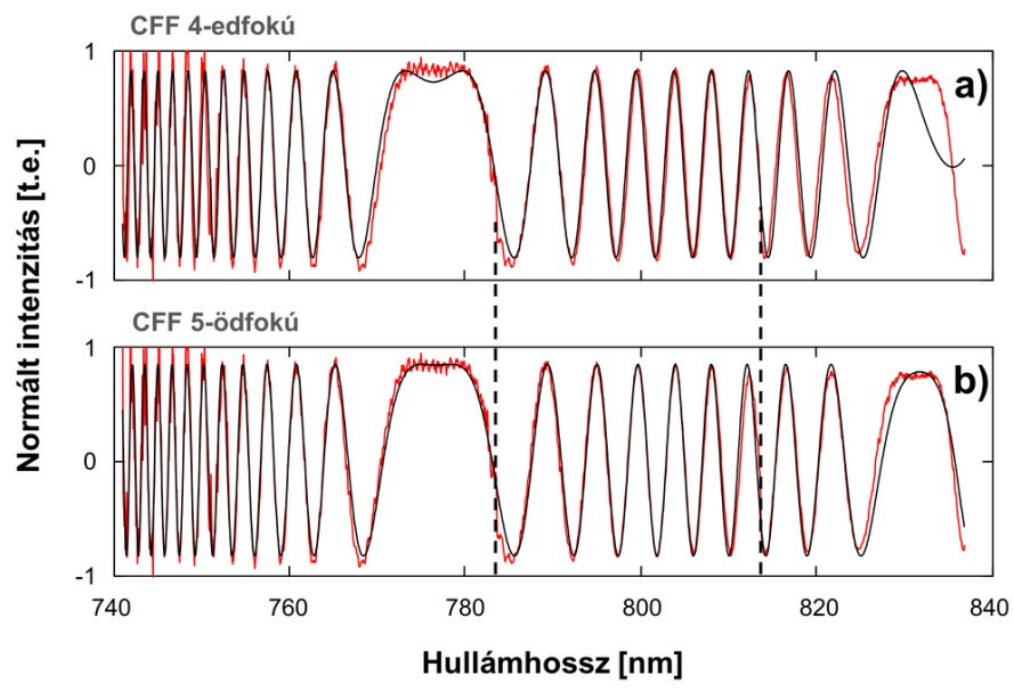

4.20 ábra Normált interferogramok (piros) az illesztett (a) negyed- és (b) ötödfokú koszinusz-függvénnyel (fekete) a koszinusz-függvény illesztés módszerét alkalmazva. A szivárgó módusokhoz tartozó hullámhosszakat szaggatott vonalak jelölik.

Amint azt korábban láthattuk, a Bragg-szál transzmissziós spektrumában rezonanciák láthatók 783 és 813 nm környékén (4.18c) ábra), ahol a spektrális fázisfüggvényben is éles csúcsok megjelenése várható. Mivel a CFF-módszer esetén az illesztett koszinusz-függvény és a normált interferogram között ezen abszorpciós völgyek közelében nem figyelhető meg jelentősebb különbség, elmondható, hogy ez a módszer nem teszi lehetővé efféle rendellenességek detektálását. Ezen megfigyelés ellenére azonban elmondható, hogy a CFF-módszer alkalmas magasabb rendủ diszperzió mérésére. Továbbá, megfigyeltem, hogy az illesztés sokkal érzékenyebb a magasabb rendek jelenlétére, ha mindkét SPP a kiértékelési tartományon belül volt.

\subsubsection{Kiértékelés Fourier-transzformációs módszerrel}

Ebben az alfejezetben a FT-módszerrel kapott eredményeimet mutatom be. 17 interferogram került rögzítésre a módszer által megkövetelt nagyobb késleltetések (-5700tól -2100, valamint 1200-tól 5500 fs között), illetve sürü csíkrendszer esetén. A kiértékelés lépései 4.21 a)-c) ábrákon láthatók. A lineáris fázistag kivonásra került a meghatározott spektrális fázisból, hogy a magasabb rendü tagok - különös tekintettel a $T O D$-ra, melynek dominanciája a két SPP megjelenésével már bizonyított - hatása jobban látszódjon. Az FT- 
módszer érzékenységét magasabb rendü diszperziók esetén a meghatározott spektrális fázisgörbére történő negyed- és ötödfokú polinom illesztésével teszteltem. 4.21 d) és e) ábrák mutatják a mért és az illesztett fázisgörbe közötti eltérést ebben a két esetben. Bár a spektrális fázisban mindkét esetben megfigyelhetők a rezonanciák közelében bekövetkező éles ugrások, mégis jól látszik, hogy az ötödfokú polinom illesztése, azaz az ötödrendű diszperzió jelenlétének feltételezése vezet pontosabb illeszkedésre. Megállapítható, hogy az FT-módszer igen pontos magasabb rendü diszperzió esetén is, valamint igen érzékeny és alkalmas a spektrumban jelen levő abszorpciós csúcsok miatt fellépő fázisugrások detektálására (2. táblázat).
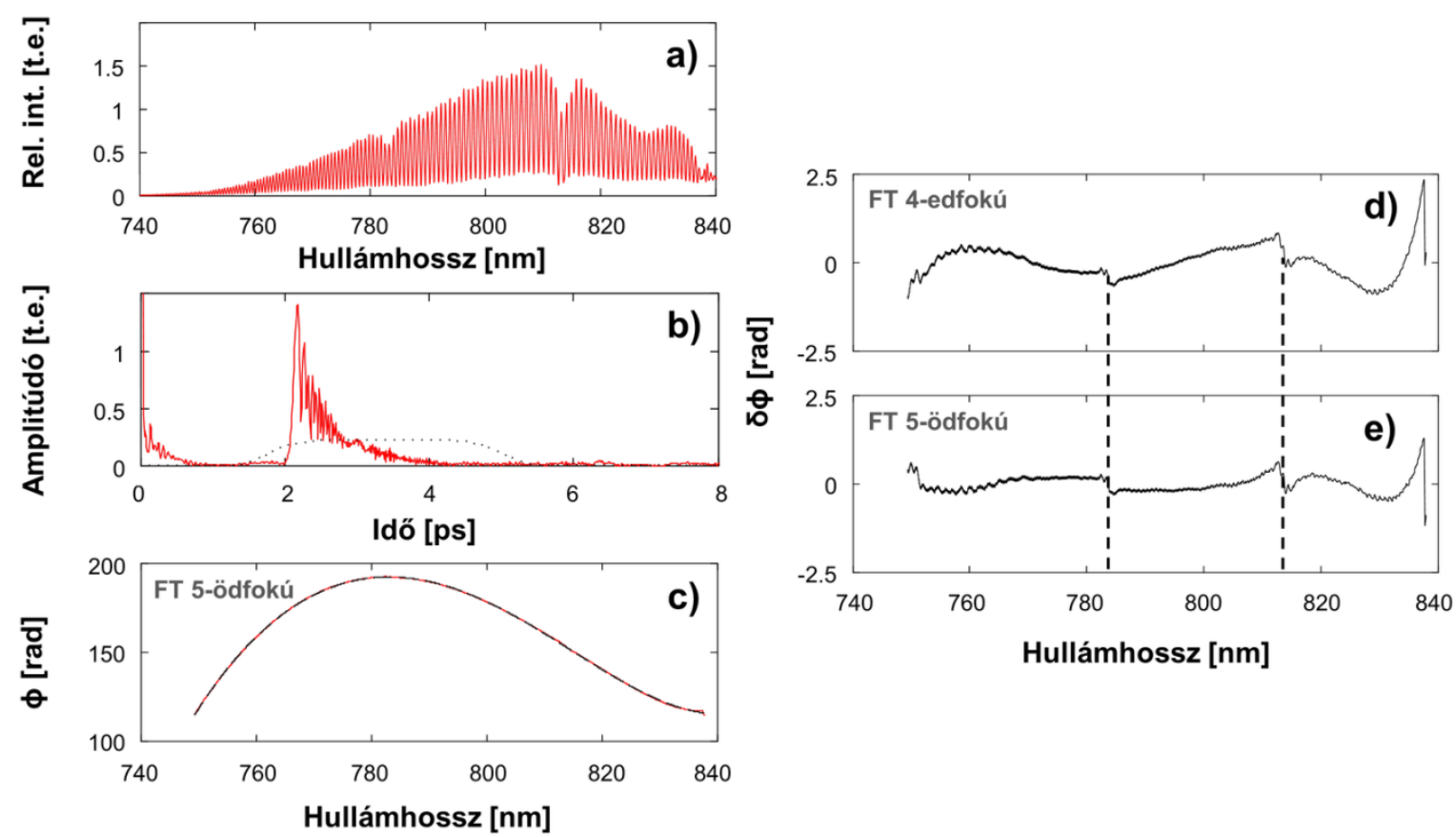

4.21 ábra (a) Egy tipikus felvett spektrálisan bontott interferogram, (b) az interferogram Fouriertranszformáltja, és (c) a Fourier-transzformációs módszerrel meghatározott (piros) és az illesztett (fekete szaggatott) spektrális fázisgörbe a lineáris tag nélkül. A mért és az illesztett fázisgörbe közötti eltérés (d) negyedfokú és (e) ötödfokú polinom illesztése esetén. A szivárgó módusokhoz tartozó hullámhosszakat szaggatott vonalak jelölik.

\subsubsection{Kiértékelés az ablakolt Fourier-transzformációs módszerrel}

Ugyanazon 17 interferogramot, melyeket az FT-módszerrel kiértékeltem, WFRmódszerrel is megvizsgáltam. Egy felvett interferogram WFT jele a 4.22 a) ábrán látható. A legpontosabb csoportkésleltetés-görbe $\Delta \Omega=0.003$ PHz-es ablakszélesség esetén adódott. 200 különböző központi frekvenciájú ablakfüggvényt használtam az interferogram teljes 
spektrális tartományának lefedésére. Az ablakolt interferogramokon végzett Fouriertranszformáció után az interferencia tagok időbeli hossza körülbelül 1 ps volt. Ezen csúcs pozíciója időtartományban 10 fs-os pontossággal került meghatározásra. A csoportkésleltetés-görbe meghatározása után először egy harmadfokú polinomot illesztettem, hogy az együtthatókat negyedrendig határozzam meg. Hasonlóan a korábbi a mérésekhez, a későbbiekben egy negyedfokú polinommal közelítettem a mért $G D$-görbét, hogy ötödrendig határozzam meg a koefficienseket (2. táblázat). Ahogyan az a 4.22 b)-c) ábrákon látható, a harmadfokú polinom illeszkedése kevésbé pontos, mint a negyedfokúé, mely esetében az eltérés a 0 körül ingadozik, kivéve természetesen a szivárgó módusok közelében, ahol éles ugrások látszanak.
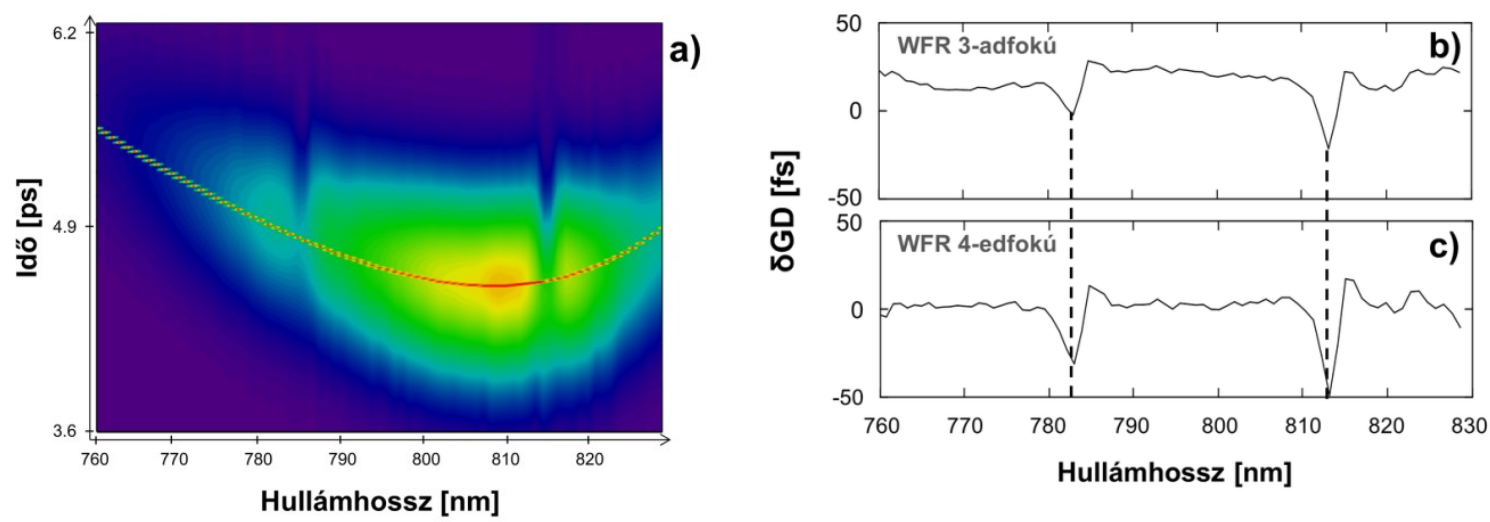

4.22 ábra (a) Az interferogram ablakolt Fourier-transzformáltja a mért csoportkésleltetés-görbével. A mért és az illesztett csoportkésleltetés-görbe közötti eltérés (b) harmadfokú és (c) negyedfokú polinom illesztése esetén. A szivárgó módusokhoz tartozó hullámhosszakat szaggatott vonalak jelölik.

A WFR-módszer eredményei a többi módszer alkalmazása során tett következtetésekkel egybehangzóan szintén azt mutatják, hogy indokolt az együtthatókat ötödrendig meghatározni. Kiemelendő, hogy a WFR-módszer is alkalmasnak bizonyult a spektrális fázisgörbében jelenlevő ugrások kimutatására az illesztett polinom fokszámától függetlenül. A módszer hátránya azonban, hogy kissé nagy a számolásigénye, így időigényes.

A különböző módszerek esetén meghatározott fázisderiváltakat a 2. táblázatban foglaltam össze. Jól látszik, hogy a FT-módszer esetén adódtak legkisebb szórással (2-6\%) az együtthatók, ami feltehetően annak köszönhető, hogy ezen módszer esetén a fázisgörbe a frekvencia kvázi-folytonos függvényeként direkt adódik, polinomillesztésre csak akkor van szükség, ha a konkrét fázisderiváltakat is meg akarjuk határozni. A CFF-módszer szintén igen pontos (2-17\%), míg a WFR-módszer pontossága (magasabb rendek esetén 
eléri az 58\%-ot) alulmúlja az FT- és CFF-módszerekét. A WFR-módszernél nagy spektrális felbontásra volt szükség, hogy a szivárgó módusokhoz tartozó ugrásokat fel tudja bontani, aminek következtében az ablakolt interferogram Fourier-transzformáltja jelentősen megnyúlt időben és a csúcsok meghatározása pontatlanabb lett. Az SPP- (akár 27\%) és MM-módszerek (akár 50\%) pontossága szintén kissé alulmarad a többi kiértékelési eljáráshoz viszonyítva.

Összehasonlítva egy azonos hosszúságú, kvarchasáb esetében mérhető GDD ( 13360 fs ${ }^{2} 800 \mathrm{~nm}$-en) értéket a vizsgált tömörmagú szál $G D D$-jével, jól látszik, hogy utóbbi körülbelül egy nagyságrenddel kisebb, ami minden bizonnyal a szálra jellemző anomális hullámvezető diszperzió eredménye [91]. A csökkentett $G D D$ hozadéka a megnövekedett $T O D$ is, ami a kvarcból készült hagyományos optikai szál esetében körülbelül egy nagyságrenddel kisebbre becsülhetö ( 10152 $\mathrm{fs}^{3} 800 \mathrm{~nm}$-en). Ezen megfigyelés továbbá megerősítésre kerül a két SPP megjelenésével az interferogramokon.

2. táblázat A 37 cm hosszúságú Bragg-típusú mikrostruktúrált optikai szál diszperziós együtthatói az öt kiértékelési módszerrel.

\begin{tabular}{cccccc} 
& SPP & MM & CFF & FT & WFT \\
\hline$G D D\left[\mathrm{fs}^{2}\right]$ & $2116 \pm 260$ & $1980 \pm 192$ & $2086 \pm 45$ & $2076 \pm 30$ & $2985 \pm 220$ \\
$T O D\left[10^{5} \mathrm{fs}^{3}\right]$ & $1.324 \pm 0.045$ & $1.17 \pm 0.19$ & $1.272 \pm 0.031$ & $1.244 \pm 0.023$ & $1.273 \pm 0.035$ \\
$F O D\left[10^{6} \mathrm{fs}^{4}\right]$ & $-1.94 \pm 0.34$ & $-1.27 \pm 0.31$ & $-1.94 \pm 0.34$ & $-1.893 \pm 0.060$ & $-1.82 \pm 0.40$ \\
$Q O D\left[10^{7} \mathrm{fs}^{5}\right]$ & $1.95 \pm 0.53$ & $1.06 \pm 0.52$ & $2.11 \pm 0.13$ & $2.21 \pm 0.13$ & $2.4 \pm 1.4$ \\
\hline
\end{tabular}

\subsubsection{A fejezethez kapcsolódó tézispont}

T2. Öt kromatikus diszperzió meghatározására alkalmas, spektrális interferometrián alapuló kiértékelési eljárást hasonlítottam össze egy megrendelésre készült 37 cm hosszúságú Bragg-szál magasabb rendü diszperziójának meghatározására a 740-840 nm-es hullámhossztartományon. Kimutattam, hogy az állandó fázisú pont és a minimum-maximum módszer kevéssé, míg a fázismodulált koszinusz-függvény illesztésén alapuló kiértékelési eljárás már kellőképpen érzékeny a magasabb rendek jelenlétére. Az ablakolt Fourier-transzformációs kiértékelés pontossága alulmúlta a várakozásokat. Megállapítottam, hogy a vizsgált Bragg-szál esetében a hagyományos Fouriertranszformáción alapuló kiértékelési eljárás szolgáltatta a legnagyobb pontossággal a 
diszperziós együtthatókat egészen ötödrendig, illetve, hogy a vizsgált kiértékelési eljárások közül csupán a két, Fourier-transzformáción alapuló módszer alkalmas a szál spektrumában megjelenő szivárgó módusok okozta fázisugrások pontos kimutatására [116]. 


\subsection{A HC-800-02 típusú fotonikus optikai szál polarizációfüggö diszperziójának kísérleti vizsgálata}

Az alábbi fejezetben a 2.1.4.2 fejezetben bemutatott légmagos fotonikus optikai szál diszperziós tulajdonságait vizsgálom meg. Figyelembe véve a szálstruktúra igen specifikus voltát, feltételezhető, hogy a gyártás után a geometria kisebb-nagyobb mértékben eltér majd a tervezettől. Ennek vizsgálatára egy rövid szálminta megfelelő előkészítése után az intézetünkben hozzáférhető Hitachi-S4700 típusú pásztázó elektronmikroszkóp segítségével több nagyítás mellett képeket vettünk fel, melyeket a 4.23 ábrán mutatok be. A képeken megfigyelhető törmelékanyag a szál vágásának tökéletlenségéből származik, azonban esetemben ez nem befolyásolta a képek elemzését. A 2.5 ábrán bemutatott, a gyártó prospektusából származó keresztmetszeti képpel történő összevetésből jól látszik, hogy a mag körüli régióban a csatornák nem követik a tervezett geometriát, az ötszögletü csatornák sokkal kisebb átmérővel rendelkeznek, mint a hatszögletűek. Effajta struktúrák anizotrópia, illetve kettőstörés kialakulásával járhatnak, melynek következtében a szálban gerjesztődő két ortogonális polarizációs módus eltérő sebességgel fog terjedni, köztük pedig késleltetés, $D G D$ lép majd fel. A továbbiakban ezért a HC-800-02 PCF mindkét polarizációs iránya mentén megvizsgálom a diszperziót.

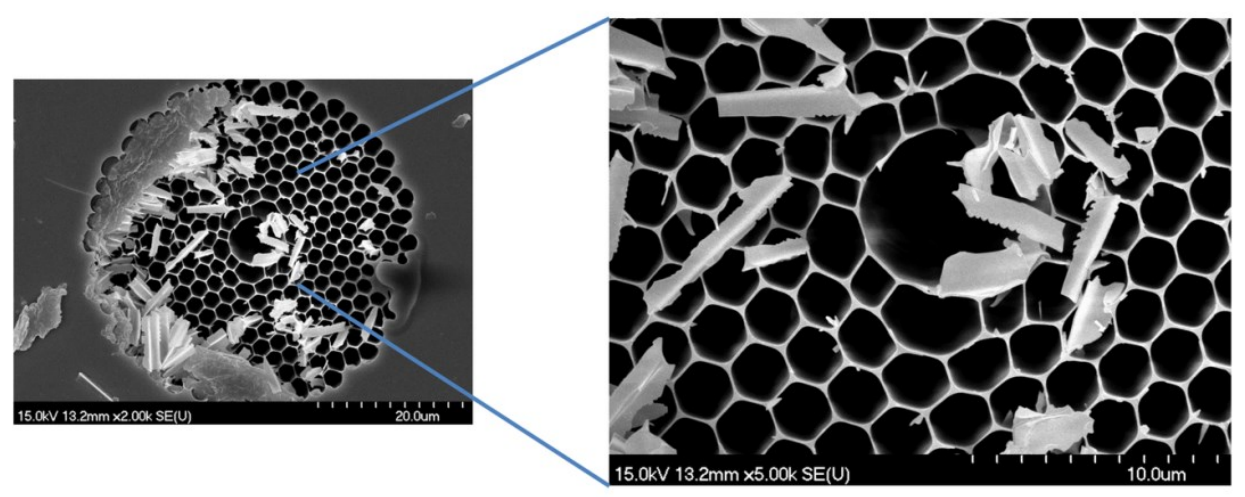

4.23 ábra A HC-800-02 típusú fotonikus optikai szál SEM-mel meghatározott keresztmetszete különböző nagyítások mellett.

A szál polarizációs irányfüggő kromatikus diszperziójának kiméréséhez megépített kísérleti elrendezés egy Mach-Zehnder interferométerből és egy nagyfelbontású spektrométerből (Ocean Optics HR4000, 700-900 nm, spektrális felbontás: $0.2 \mathrm{~nm}$ ) állt (4.24 ábra). Szélessávú fényforrásként egy Ti:S oszcillátor nyalábját használtam 
(Femtolasers, Rainbow, impulzushossz: 6 fs, központi hullámhossz: 800 nm, FWHM = $150 \mathrm{~nm})$. Az elrendezés elé elhelyeztem egy polarizátort, hogy a lineáris polarizáció tisztaságát biztosítani tudjam. Ahhoz, hogy vagy csak egy, vagy akár mindkét polarizációs módust is gerjeszteni tudjam egyszerre, a szál bemenete elé a tárgykarba egy félhullámlemezt helyeztem el. Egy ugyanilyen félhullámlemez a referenciakarban is elhelyezésre került, hogy a polarizáció iránya itt is állítható legyen. A becsatolás egy 30 mm fókusztávolságú akromát lencsével történt, míg a szál kimenetének kollimálásához egy szintén akromát, $19 \mathrm{~mm}$ fókusztávolságú lencsét használtam. Ugyanezeket a lencséket a referenciakarban is elhelyeztem, hogy ezáltal a diszperziójukat kompenzáljam. A két kar intenzitásának kiegyenlítéséhez szürőt helyeztem el a tárgykarban. Tekintve, hogy ennek vastagsága mm-es nagyságrendü, a rendszer diszperziójához érdemben nem járult hozzá. $\mathrm{Az}$ interferométer másik kimenetéhez ez esetben is elhelyeztem egy CCD kamerát, hogy a becsatolást ellenőrizni tudjam. A kimenetnél elhelyezett polarizátorral az interferogram láthatóságán tudtam javítani, mivel így el tudtam érni, hogy az egymásra merőleges polarizációval rendelkező nyaláboknak a polarizátor transzmissziós tengelyére eső elektromos térerősség komponensei interferáljanak egymással. Maximális láthatóságú interferenciamintázat akkor állt elő, ha a polarizátor transzmissziós tengelye $45^{\circ}$-os szöget zárt be a nyalábok polarizációs síkjával.

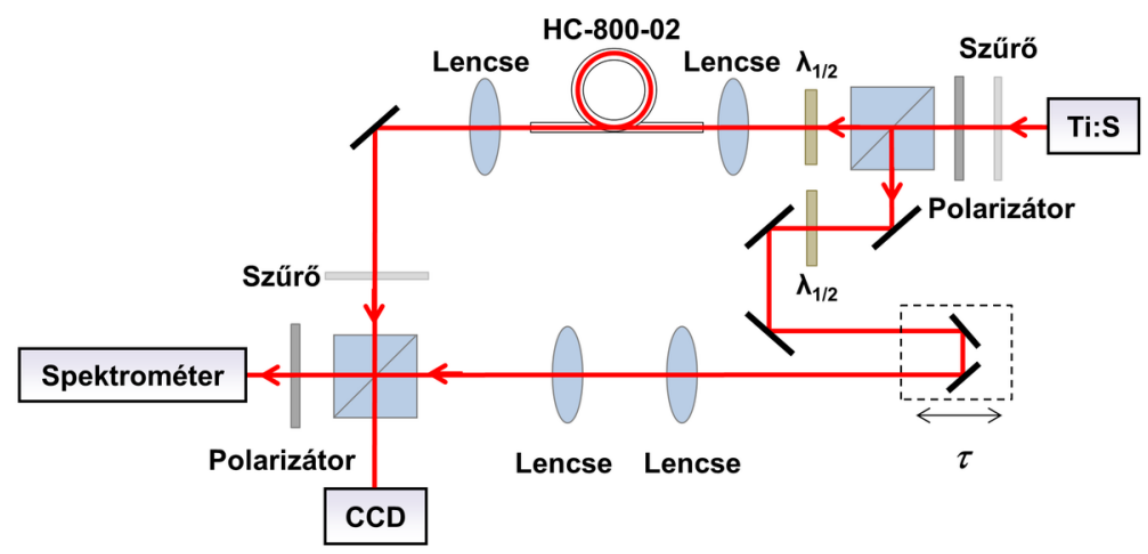

4.24 ábra Spektrálisan bontott Mach-Zehnder interferométer a HC-800-02 típusú fotonikus optikai szál diszperziójának meghatározására.

\subsubsection{A polarizációfüggő kromatikus diszperzió kísérleti vizsgálata}

Ahogy azt korábban már láthattuk, ha az optikai szál kettőstörő, igen nagy jelentősége van annak, hogy mind a gyors, mind pedig a lassú polarizációs tengely irányában méréseket végezzünk, ugyanis a két irány diszperziós viselkedése jelentősen 
eltérhet $[2,11,55,56]$. Az első mérések alkalmával a vizsgált szál hossza $97.5 \mathrm{~cm}$ volt, és enyhén belógatva helyeztem el az interferométer tárgykarjában. A félhullámlemez és kimeneti polarizátor finomállításával sikerült meghatározni az optikai szál gyors és lassú tengelyéhez tartozó szögeket, majd tetszés szerint gerjeszteni a tengelyek mentén terjedő módusokat. A 4.25 a) és b) ábrán jól látszik, hogy a szál transzmissziója mindkét polarizációs irány esetében 750 és $890 \mathrm{~nm}$ között a legnagyobb, ami összhangban van a gyártó honlapján közzétett csillapításgörbével. (2.6 ábra [26]). Látható, hogy a szál enyhén belógatott helyzetében a két spektrum között 753 és 790 nm közötti tartományban nincs számottevő különbség, mindkettő viszonylag sima, rezonanciáktól mentes. $750 \mathrm{~nm}$ környékén a lassú tengely esetén egy rezonancia látható, aminek oka általunk ismeretlen, a mérést viszont nem befolyásolta. Vegyük észre, hogy mind a szálból kijövő, mind pedig szálba belépő lézer spektrumában (4.25 c) ábra) moduláció figyelhető meg. Ennek oka lehet a lézer útjába helyezett egyik optikai elem vékonyréteg bevonatának első és hátsó oldalán történő visszaverődés, a diszperzió mérésekre azonban ez nem volt kihatással.

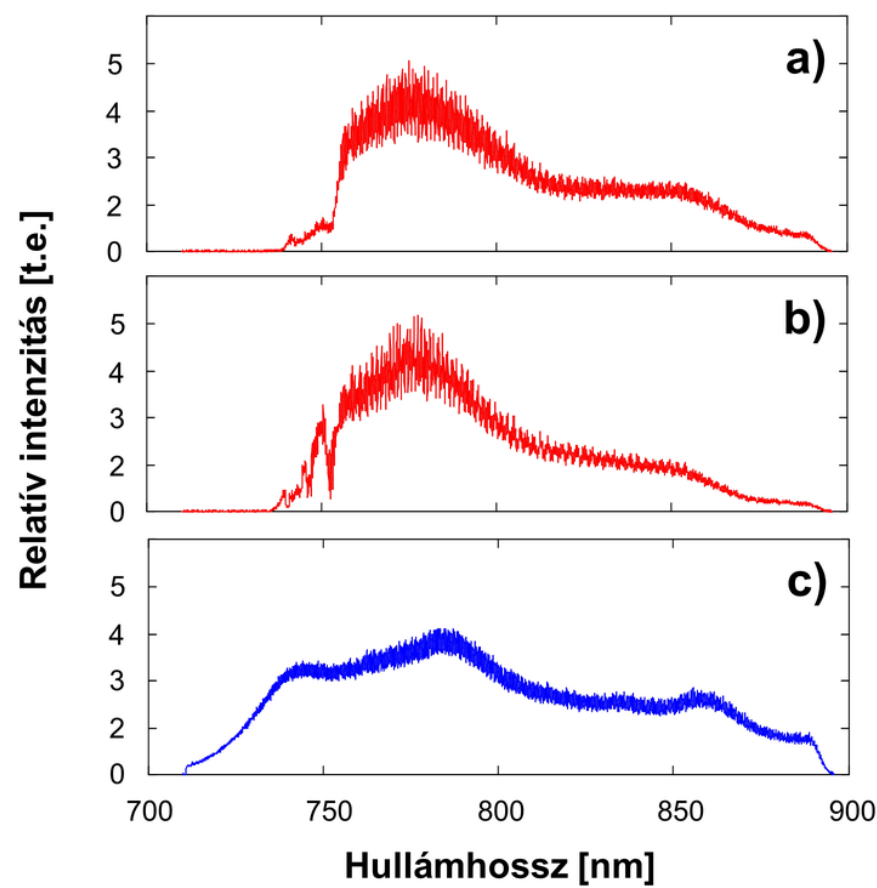

4.25 ábra A 97.5 cm hosszúságú, enyhén belógatott HC-800-02 fotonikus optikai szál (a) gyors és (b) lassú tengelyéhez tartozó transzmissziós spektrum, valamint (c) az alkalmazott Ti:S lézer spektruma.

A felvett interferogramok közül polarizációs irányonként 20 darabot a korábban megismert FT-módszerrel értékeltem ki 760-870 nm-es hullámhossztartományban. A kiértékelés lépései a 4.26 a)-c) ábrán láthatóak. A 4.26 b) ábrán megfigyelhető mellékimpulzusok a Fourier-jelben jelentős harmadrendü diszperzióra utalnak, melynek 
dominanciáját egy hasonló típusú PCF, a HC-800-01 spektrális fázisában korábban már kimutatták [34]. A lineáris tag levonása után a kapott spektrális fázisra először egy negyedfokú polinomot illesztettem, majd az illesztett görbe fokszámát addig növeltem, amíg a két görbe közötti eltérés minimális nem lett (4.26 d)-f) ábra). Ezután hiába növeltem az illesztendő polinom fokszámát, nem csökkent tovább az eltérés. Tekintve, hogy a legjobb illeszkedés a hatodrendü polinom esetén adódott, a diszperziós együtthatókat mindkét polarizációs irányban eddig a rendig határoztam meg.
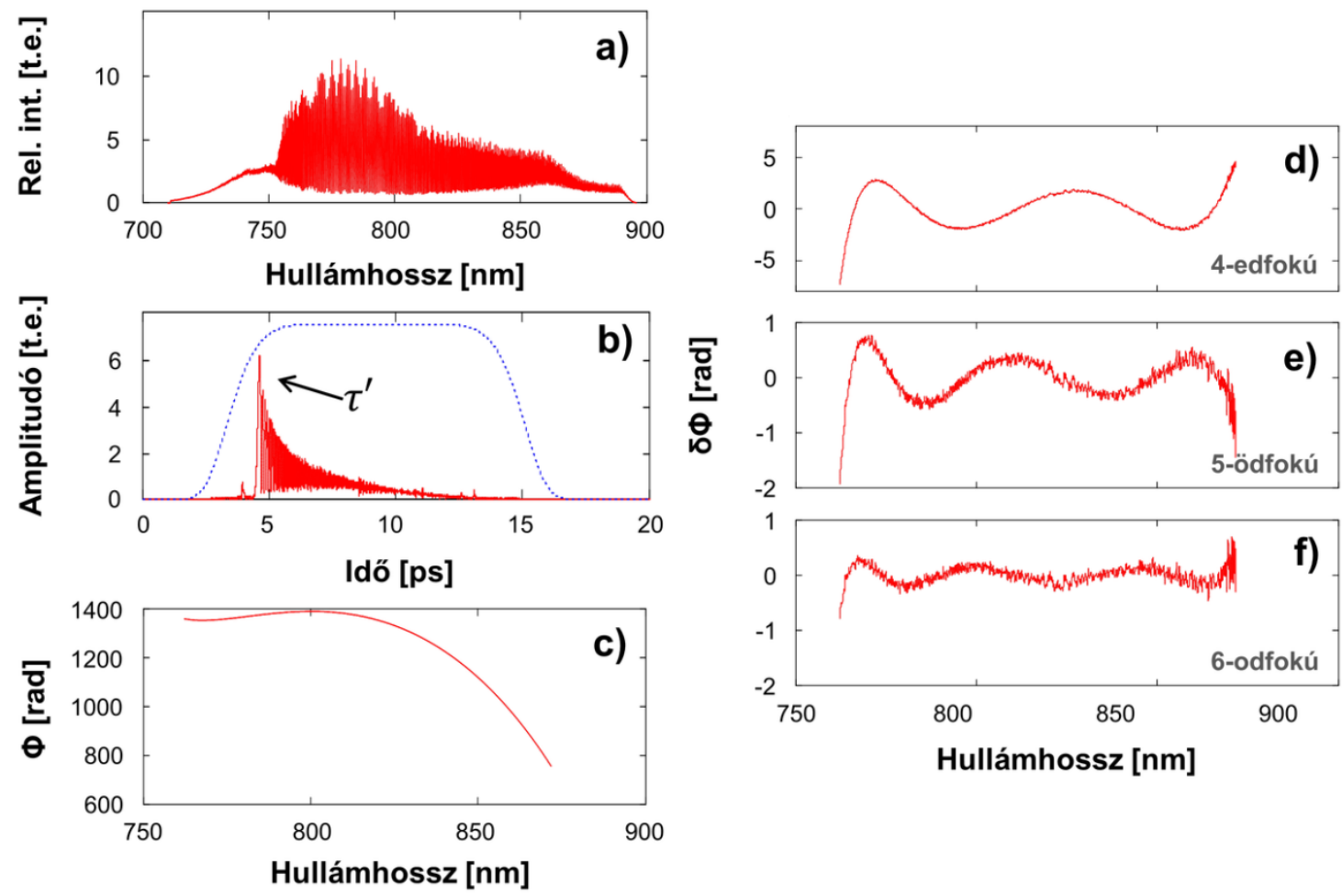

lámhossz [nm]

4.26 ábra (a) 97.5 cm hosszúságú, enyhén belógatott HC-800-02 fotonikus optikai szál esetén felvett spektrálisan bontott interferogram, (b) az interferogram Fourier-transzformáltja, (c) a Fouriertranszformációs módszerrel meghatározott spektrális fázisgörbe a lineáris tag nélkül, valamint az illesztett (d) negyedfokú, (e) ötödfokú és (f) hatodfokú polinom és a mért fázisgörbe közötti eltérés.

A 3. táblázatból látható, hogy a vizsgált optikai szál $G D D$-je negatív és hasonló hosszúságú ömlesztett kvarchasábhoz képest viszonyítva értéke jelentősen kisebb mindkét polarizációs irány esetén. A TOD és a magasabb rendek ennek megfelelően sokkal jelentősebbek. Fontos kiemelni, hogy a $G D D$-nél magasabb rendek előjele pozitív, beleértve a $F O D$-ot is, melynek előjele hagyományos üvegek esetén tipikusan negatív. 
3. táblázat A 97.5 cm hosszúságú, enyhén belógatott HC-800-02 optikai szál két polarizációs irányában mért diszperziós együtthatók a Fourier-transzformációs módszerrel.

\begin{tabular}{cccc} 
& Gyors tengely & Lassú tengely & Ömlesztett kvarchasáb \\
\hline$G D D\left[10^{4} \mathrm{fs}^{2}\right]$ & $-1.805 \pm 0.008$ & $-1.313 \pm 0.005$ & 3.530 \\
$T O D\left[10^{5} \mathrm{fs}^{3}\right]$ & $2.379 \pm 0.009$ & $3.240 \pm 0.005$ & 0.268 \\
$F O D\left[10^{6} \mathrm{fs}^{4}\right]$ & $1.899 \pm 0.011$ & $2.973 \pm 0.013$ & -0.011 \\
$Q O D\left[10^{7} \mathrm{fs}^{5}\right]$ & $6.648 \pm 0.062$ & $8.980 \pm 0.042$ & 0.003 \\
$S O D\left[10^{8} \mathrm{fs}^{6}\right]$ & $4.141 \pm 0.162$ & $8.529 \pm 0.139$ & $/$ \\
\hline
\end{tabular}

Az optikai szálak jellemzésére gyakran nem a diszperziós együtthatókat alkalmazzák, hanem az ezekből származtatható $D$ diszperziós görbét adják meg. A két polarizációs irányban (2.7) alapján meghatározott és a gyártó által megadott adatokból számolt diszperziós görbék [26] a 4.27 ábrán láthatók. A mérések pontossága vonalvastagságon belül volt. A két polarizációs irányban meghatározott görbe szinte teljesen megegyezik $815 \mathrm{~nm}$ felett, alatta azonban kissé eltér, habár ez az eltérés jóval csekélyebb, mint a hasonló szálak esetén korábban megfigyelt különbségek [20]. Annak ellenére, hogy a meghatározott diszperziós görbék nagy hasonlóságot mutattak a gyártó görbéjével, mindkettő eltér ettől, különösképpen a kisebb hullámhosszak tartományában. Ez az eltérés a lassú tengely mentén terjedő módus gerjesztésével adódó görbe esetében még inkább kifejezettebb. Az eltérés a 763 nm környékén a gyors tengely mentén terjedő módus esetében a 70\%, míg a lassú esetében akár a 198\%-ot is eléri.

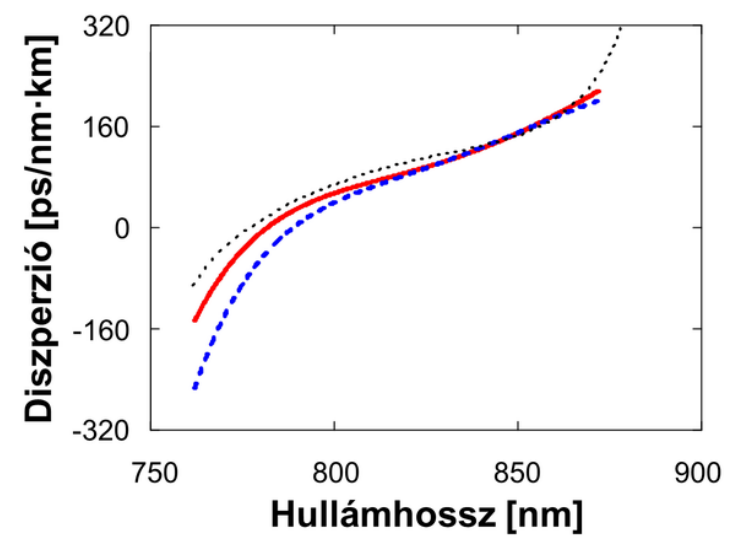

4.27 ábra A 97.5 cm hosszúságú, enyhén belógatott HC-800-02 fotonikus optikai szál diszperziós görbéi a gyors (piros) és a lassú (kék szaggatott) tengely mentén, valamint a gyártó adatai alapján számolt diszperziós görbe (fekete pontozott). 
A két polarizációs irány diszperziós tulajdonságának eltéréséből valószínüsíthető, hogy a gyors tengely polarizációs állapotával megegyező bejövő impulzust némileg más hatás éri majd, mint a lassú tengellyel azonos polarizációval rendelkező impulzust. Ezen feltevés igazolásához szimuláció segítségével megvizsgáltam milyen hatással van a HC800-02 gyors és lassú tengelye mentén mért diszperzió egy 100 fs hosszúságú, transzformlimitált impulzusra, amíg az egy $97.5 \mathrm{~cm}$ hosszúságú szálon keresztülhalad. Ahogyan az a 4.28 ábráról jól látható, a gyors tengely mentén való haladás után és a gyártó által megadott diszperzióból becsülhető impulzusalak jó közelítéssel megegyezik. Ezzel szemben a lassú tengely mentén való haladás merőben más impulzusalakot eredményez. Fontos megjegyezni, hogy időben minél rövidebb impulzust használunk, annál kifejezettebb eltérésre lehet számítani.

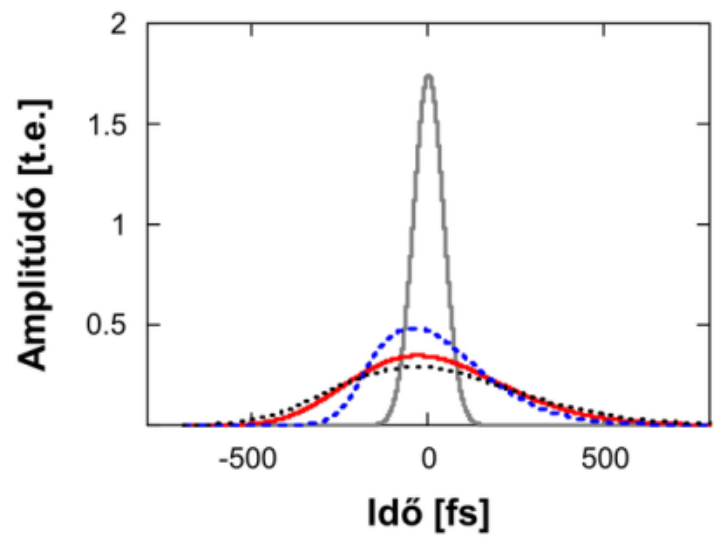

4.28 ábra A diszperzió hatása a gyors (piros) illetve a lassú (kék szaggatott) tengely polarizációjával megegyező, 100 fs időbeli félértékszélességü, transzformlimitált bejövő impulzusra (szürke) $97.5 \mathrm{~cm}$ hosszúságú, enyhén belógatott HC-800-02 fotonikus optikai szálon történő áthaladás során. A gyártó adatai alapján becsült torzulás (fekete pontozott).

\subsubsection{A kromatikus diszperzió és a fotonikus szál helyzete közötti kapcsolat} kísérleti vizsgálata

A szálakat használat közben sokszor feltekerik vagy meghajlítják, aminek következtében benne feszültségek ébredhetnek. Ilyen esetekben a szál kettőstörő és diszperziós tulajdonságai megváltozhatnak, ezért miután a HC-800-02 PCF irányfüggő diszperzióját a szál kissé belógatott helyzetében megvizsgáltam, további két pozícióban, a szálat kissé kifeszítve, valamint egy $15 \mathrm{~cm}$ átmérőjü dobra feltekerve megismételtem a korábbi méréseket. A vizsgált szálminta hossza továbbra is $97.5 \mathrm{~cm}$. Utóbbi két pozícióban kapott szálspektrumok a 4.29 ábrán láthatók. Megfigyelhető, hogy amíg a kifeszítés okozta 
kisebb feszültség nem volt különösebb hatással a szál transzmissziós spektrumára (4.29 a)b) ábra), addig a dobra való feltekerés eredményeképpen éles levágás figyelhető meg 775 nm környezetében, mely különösképpen a gyors polarizációs irány esetében igen meredek (4.29 c)-d) ábra).

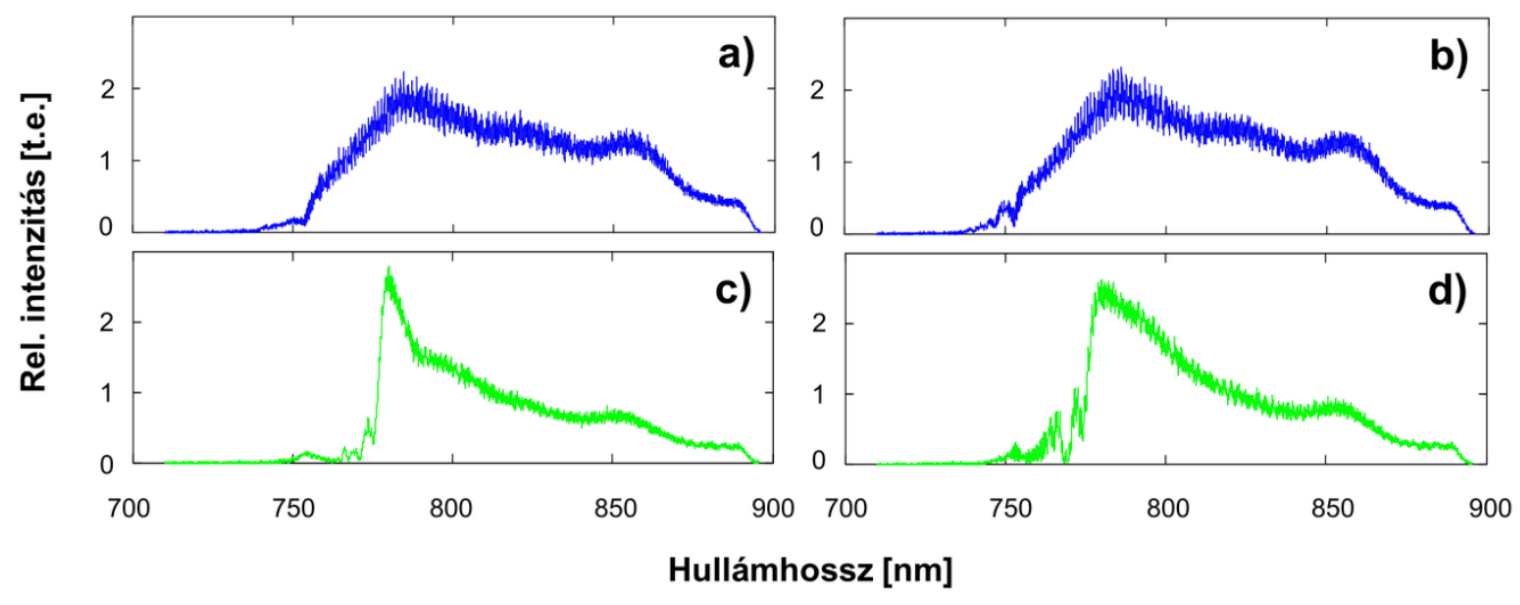

4.29 ábra A HC-800-02 fotonikus optikai szál különböző pozícióihoz tartozó transzmissziós spektrumok: kifeszített helyzetben (kék) (a) a gyors és (b) a lassú tengely mentén, valamint feltekert helyzetben (zöld) (c) a gyors és (d) a lassú tengely mentén.

A szál belógatott és kifeszített helyzetében, valamint a dobra való feltekerés után kapott diszperziós görbék a 4.30 ábrán láthatók.
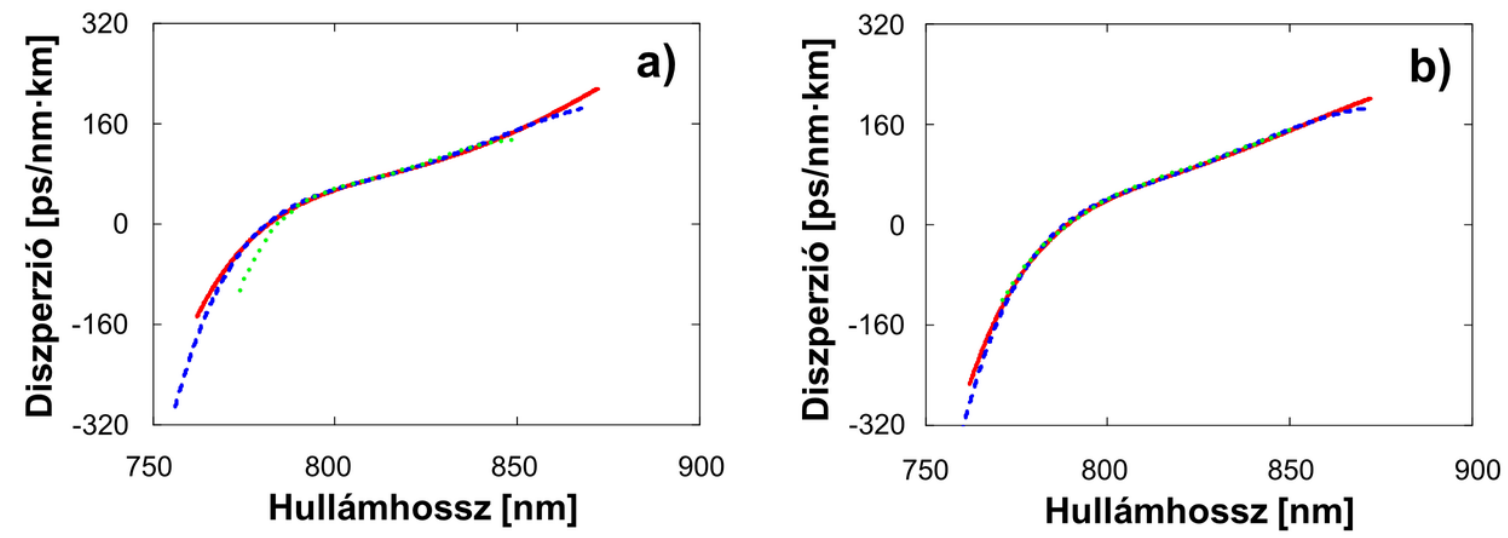

4.30 ábra A 97.5 cm hosszúságú HC-800-02 fotonikus optikai szál diszperziós görbéi (a) a gyors és (b) a lassú tengely mentén különböző pozíciókban: enyhén belógatott (piros), kifeszített (kék szaggatott) és feltekert helyzetben (zöld pontozott).

Úgy, ahogy a spektrumok esetében, a kifeszítés a diszperziós görbék tekintetében sem okozott jelentős változást, azonban a feltekert helyzetben kimért diszperziós görbe a gyors tengely esetén a rövidebb hullámhosszak környezetében kissé eltér mind a 
belógatott, mind pedig a kifeszített helyzetben meghatározott görbéktől (4.30 a) ábra). Ahogy azt korábban kimutatták [117], attól függően, hogy a feltekerés iránya melyik polarizációs tengellyel esik egybe, a gyors és a lassú tengely mentén eltérő feszültség ébred, ami egyúttal magyarázza is a fent tapasztalt viselkedést. A kisebb eltérések ellenére elmondható, hogy a szál diszperziója mindkét polarizációs irány esetén függetlennek tekinthető a szál pozíciójától, ezért a későbbi méréseket csak a szál kissé belógatott helyzetében végeztem el.

\subsubsection{A kromatikus diszperzió és a fotonikus szál hossza közötti kapcsolat}

\section{kísérleti vizsgálata}

Tekintve, hogy egészen kicsi, a szál hosszában többnyire egyenlőtlenül előforduló hibák a geometriában jelentősen befolyásolhatják a szál optikai tulajdonságait, a különböző hosszúságú minták eltérő diszperziós viselkedést mutathatnak. Fontos lenne megvizsgálni, hogy lehetséges-e rövid szálak mérési eredményeiből következtetni hosszabb szálak viselkedésére, ami új típusú optikai szálak fejlesztésekor igen költségtakarékos lenne. Ehhez a vizsgált szálból rövidebb minták levágása után a korábbi diszperzió méréseket mindkét polarizációs irányban megismételtem, majd összehasonlítottam a korábbi eredményekkel.

Az enyhén belógatott pozícióhoz tartozó 97.5, 53.5, 21.4 és $10.1 \mathrm{~cm}$ szálhosszak esetén kapott diszperziós görbék a 4.31 ábrán láthatók.
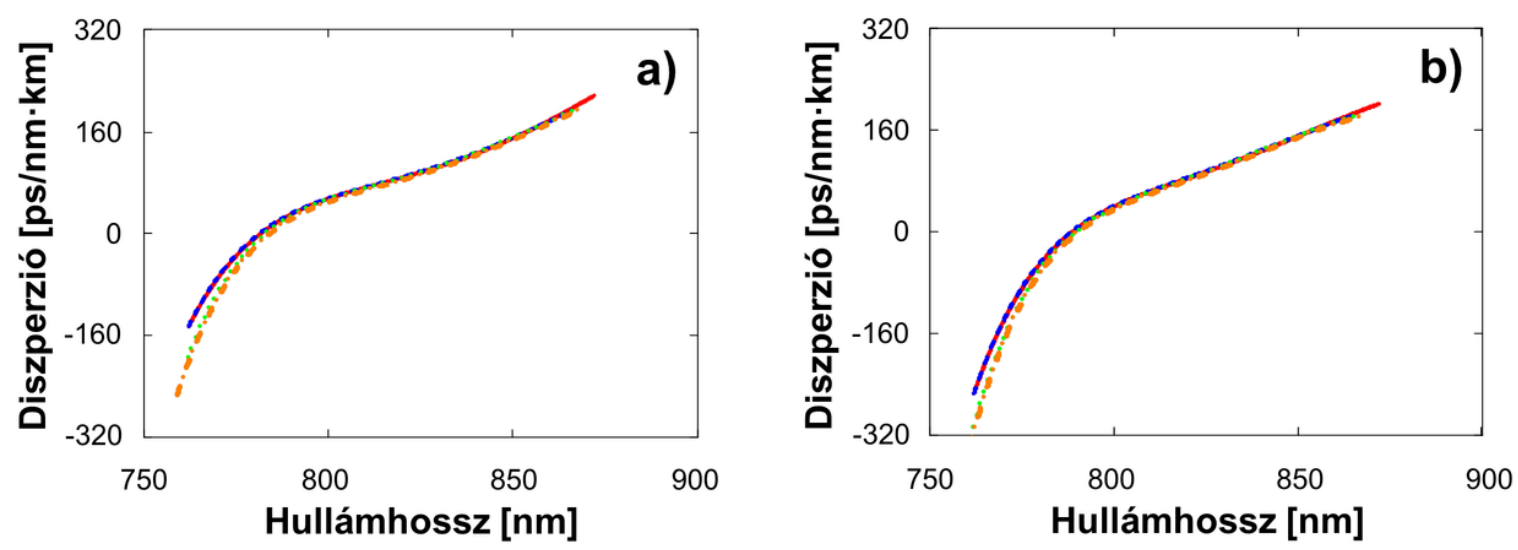

4.31 ábra Enyhén belógatott HC-800-02 fotonikus optikai szál diszperziós görbéi (a) a gyors és (b) a lassú tengely mentén különböző szálhosszúságok esetén: $97.5 \mathrm{~cm}$ (piros), $53.5 \mathrm{~cm}$ (kék szaggatott), $21.4 \mathrm{~cm}$ (zöld pontozott) és $10.1 \mathrm{~cm}$ (narancssárga szaggatott-pontozott). 
Jól látszik, hogy a két hosszabb (97.5 és $53.5 \mathrm{~cm}$ ) és a két rövidebb (21.4 és 10.1 $\mathrm{cm}$ ) minta esetén a $D$ görbék páronként szinte tökéletes egyezést mutatnak mindkét polarizációs irányban. Ha azonban a hosszabb és a rövidebb szálak $D$ görbéit hasonlítjuk össze, kisebb eltéréseket figyelhetünk meg a $800 \mathrm{~nm}$ alatti tartományban. Ezen eltérések azonban nem olyan jelentősek, ugyanis az impulzusra gyakorolt hatásuk tekintetében nem számottevők ezek a különbségek. Összefoglalva elmondható, hogy a tapasztalatok azt mutatták, hogy a vizsgált HC-800-02 szál geometriája többé-kevésbé egységesnek tekinthető, azaz a szál diszperziója mindkét polarizációs irány mentén additív.

\subsubsection{A fejezethez kapcsolódó tézispont}

T3. Kísérletileg meghatároztam 1 méternél rövidebb HC-800-02 fotonikus optikai szálminták polarizációs irányfüggő kromatikus diszperzióját hatodrendig Fouriertranszformációs spektrális interferometria alkalmazásával a 760-870 nm-es hullámhossztartományban. Megállapítottam, hogy a szál két polarizációs irányához tartozó diszperziós görbék különböznek: a gyors tengely mentén haladó módus gerjesztésével meghatározott görbe a kisebb hullámhosszak tartományában esetenként 70\%, míg a lassú tengely mentén terjedő jelentősebb, 198\%-os eltérést mutatott a gyártó által megadott adatokból számolt görbétől. A szál mindkét polarizációs irányában a mért $G D D$ negatív és abszolút értékben is kisebb, mint hasonló hosszúságú, hagyományos ömlesztett kvarcalapú egymódusú szálak esetén várható. A magasabb rendủ tagok mind pozitív előjelủek, és hogy a TOD a domináns tag. Kimutattam, hogy a szál diszperziója mindkét polarizációs irány esetén független a szál pozíciójától és annak hosszától [118]. 


\subsection{A HC-800-02 típusú fotonikus optikai szál polarizációs módusdiszperziójának kísérleti meghatározása}

Ahogyan azt a 2.1.2 fejezetben láthattuk, az optikai szál PMD-je leírható a csoportkésleltetés-különbség, azaz $D G D$ bevezetésével, mely tulajdonképpen az egymásra merőleges polarizációs irányok között fellépő időbeli késleltetést jelenti. A $D G D$ meghatározásának két lehetséges módját vizsgálom meg az alábbiakban.

\subsubsection{A csoportkésleltetés-különbség indirekt meghatározása}

A $D G D$ indirekt módon meghatározható az egyes polarizációs irányokban különkülön kimért, azonos késleltetéshez tartozó, például FT-módszerrel meghatározott $G D$ görbék egymásból történő kivonásával. Ahogyan az a 4.32 a) ábráról is látható, az így meghatározott $D G D$-görbék még azonos hosszúságú, különbözőképpen elhelyezett szálak esetében is mutatnak kisebb eltéréseket. A rövid szálak esetén ugyanilyen viselkedés tapasztalható (4.32 b) ábra).
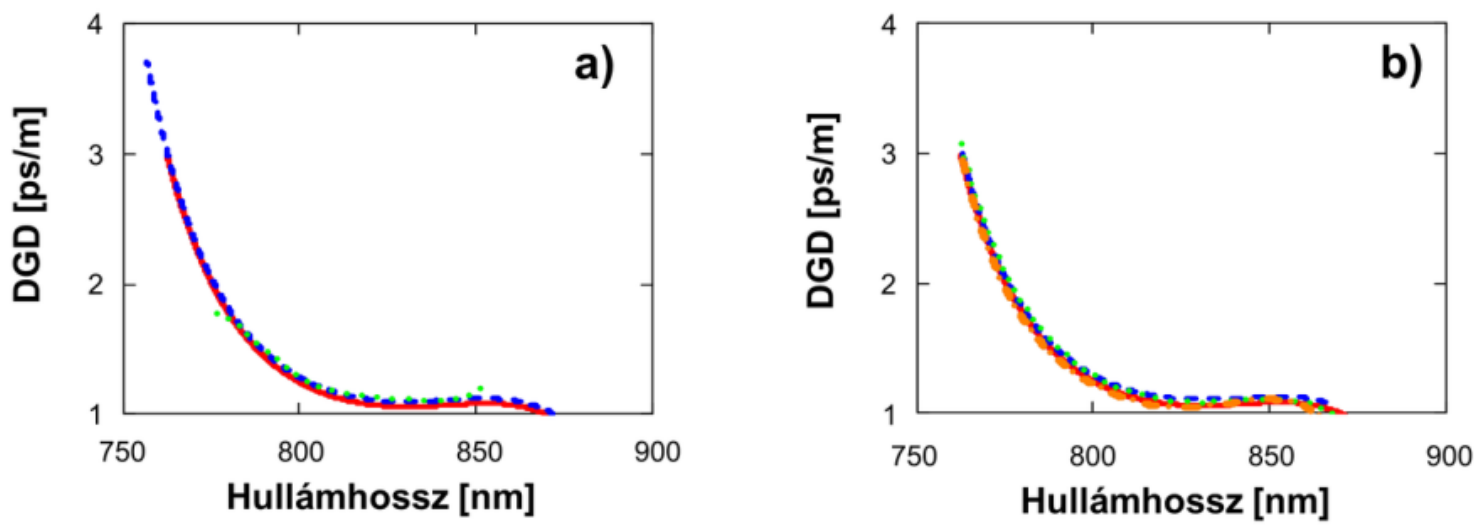

4.32 ábra Indirekt módon meghatározott $1 \mathrm{~m}$-es szálhosszúságra vonatkoztatott csoportkésleltetés-különbség görbék (a) a 97.5 cm-es szál esetén enyhén belógatott (piros), kifeszített (kék szaggatott) és feltekert helyzetben (zöld pontozott), valamint (b) különböző szálhosszúságok esetén: $97.5 \mathrm{~cm}$ (piros), $53.5 \mathrm{~cm}$ (kék szaggatott), $21.4 \mathrm{~cm}$ (zöld pontozott) és $10.1 \mathrm{~cm}$ (narancssárga szaggatott-pontozott) enyhén belógatott helyzetben.

Fontos kiemelni, hogy elsőként a gyors tengely mentén terjedő polarizációs módus gerjesztésével kerültek rögzítésre az interferogramok különböző késleltetéseknél, majd ugyanezen késleltetések lettek beállítva a lassú tengely mentén haladó módus gerjesztésével. A $D G D$-görbéknél tapasztalható eltérések, feltehetően többek között 
magyarázhatók tehát azzal, hogy a késleltetéseket körülbelül $2 \mu \mathrm{m}$-es pontossággal tudtam beállítani, ami az egyes irányokban meghatározott $G D$-görbék pontosságát is befolyásolhatja. Következésképpen, a $D G D$ indirekt meghatározása két mérés hibáját tartalmazhatja, ami egyrészről adódhat az adott polarizációs módus nem tökéletes gerjesztéséből, másrészről pedig a késleltető elem eltolójának pontatlanságából is.

\subsubsection{A csoportkésleltetés-különbség direkt meghatározása}

A PMD direkt módon is mérhető, mégpedig a két polarizációs módus azonos idejü gerjesztésekor adódó interferogram kiértékelésével. Ehhez a tárgykarban lévő félhullámlemezt, valamint a kimenetnél elhelyezett polarizátort az optikai szál két polarizációs irányához képest $45^{\circ}$-os szögben kell beállítani, és a referenciakarból jövő nyalábot kitakarni. A 4.33 ábráról jól látszik, hogy az így előállított interferogram láthatósága szinte 100\%, ami bizonyítja, hogy a két ortogonális módus azonos mértékben gerjesztődött, majd interferált egymással, ahogyan azt [36]-ban is láthattuk.

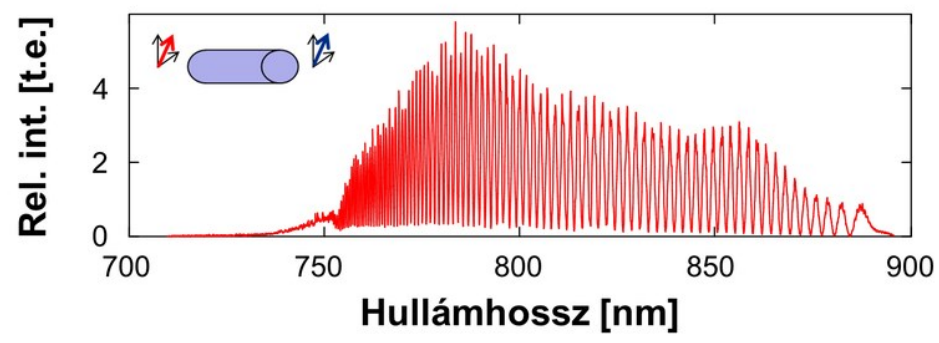

4.33 ábra Interferencia a két egymásra merőleges polarizációs irány között a $97.5 \mathrm{~cm}$ hosszúságú, kifeszített szál esetén. A betétábra mutatja a tárgykarban lévő félhullámlemez (piros nyíl) és a kimenetnél elhelyezett polarizátor pozícióját (kék nyíl).

Fontos megjegyezni, hogy az említett tanulmány eredményeivel ellentétben, ahol az SPP 846 nm-nél jelet meg, esetünkben 900 nm környékén volt megfigyelhető. Ez különösen azért érdekes, mert az SPP ez esetben a szálhossztól függetlenül ugyanott kellene, hogy megjelenjen (ld. 4.34 ábra), tekintve, hogy két, ugyanolyan típusú szálról van szó. A tapasztalt eltérés viszont arra utal, hogy a két esetben vizsgált HC-800-02 szál geometriája nem tökéletesen egyezett meg. Ennek értelmében igazolást nyert a feltevés, miszerint nem lehetséges teljesen megegyező struktúrájú szálakat gyártani, azaz a modellezéssel kialakított geometriát és optikai tulajdonságokat nem mindig sikerül reprodukálni. Ebből következik, hogy ha pontosan ismerni szeretnénk az adott fotonikus szál optikai paramétereit, akkor szükséges ezeket méréssel is meghatározni. 


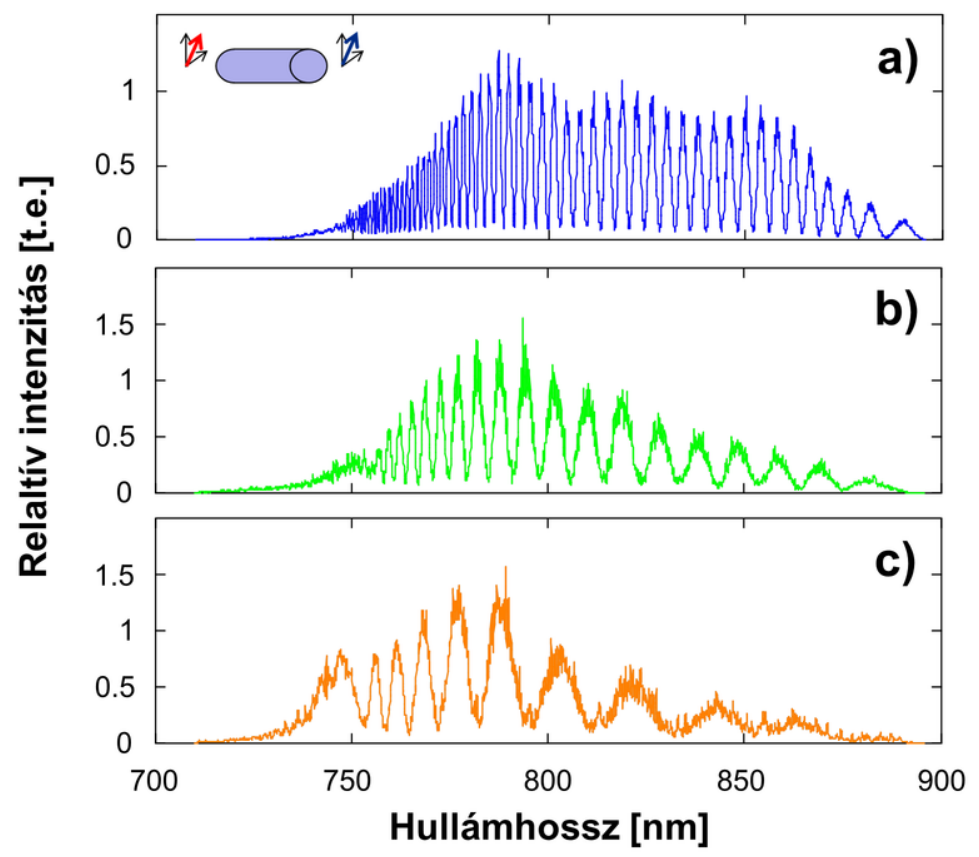

4.34 ábra Interferencia a két egymásra merőleges polarizációs irány között (a) az 53.5, (b) a 21.4 és (c) a $10.1 \mathrm{~cm}$ hosszúságú, enyhén belógatott szál esetén. A betétábra mutatja a tárgykarban lévő félhullámlemez (piros nyíl) és a kimenetnél elhelyezett polarizátor pozícióját (kék nyíl).

A fenti interferogramok FT-módszerrel történő kiértékelésével a két polarizációs irány közötti $D G D$ direkt módon adódik. A különböző pozíciókban elhelyezett $97.5 \mathrm{~cm}$ hosszúságú szál ilyen módon meghatározott 1 m-re vonatkoztatott $D G D$-görbéi a 4.35 a) ábrán láthatók. Jól látszik, hogy amíg az indirekt módon meghatározott $D G D$-görbéknél eltérés tapasztalható (4.32 a) ábra), ez esetben a görbék teljesen megegyeznek. A szál hosszának csökkentése után kapott $D G D$-görbék a 4.35 b) ábrán láthatók. Tekintve, hogy a rövidebb szálak esetén a két tengely interferenciájából adódó mintázat fokozatosan kiritkul (4.34 ábra), a két legrövidebb, azaz a 21.4 és a $10.1 \mathrm{~cm}$ hosszúságú szál esetén az interferogramot már nem a FT-módszerrel, hanem a MM-módszerrel értékeltem ki. Amíg az 53.5 és a $21.4 \mathrm{~cm}$-es szál $D G D$-görbéje igen jól illeszkedik a $97.5 \mathrm{~cm}$ hosszúságú minta $D G D$-görbéjéhez, addig a $10.1 \mathrm{~cm}$ némileg nagyobb eltérést mutat (narancssárga szaggatott-pontozott vonal a 4.35 b) ábrán). Ezen eltérés oka feltehetően az interferogramon látható minimumok és maximumok számának csökkenése, ami a szál rövidülésének, ezzel együtt pedig a diszperzió csökkenésének velejárója. Hosszabb szálminták esetén a leolvasott szélsőértékek számának növekedése tipikusan nagyobb pontosságot eredményez. 

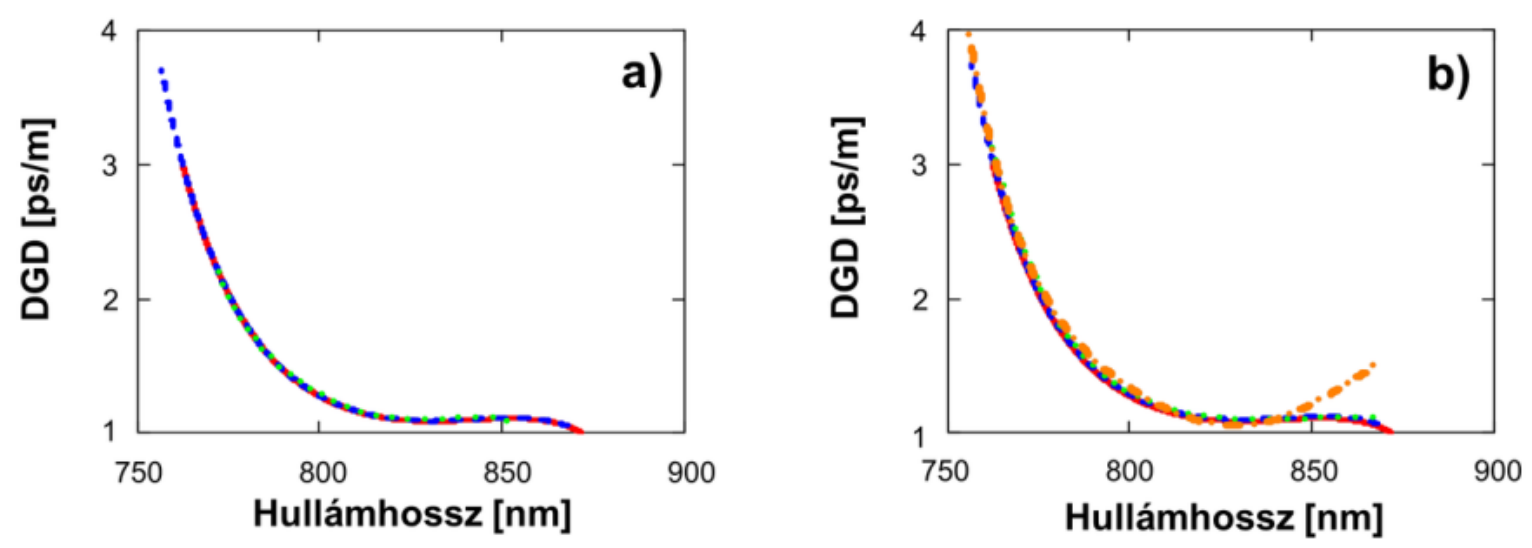

4.35 ábra Direkt módon meghatározott 1 m-es szálhosszúságra vonatkoztatott csoportkésleltetés-különbség görbék (a) a $97.5 \mathrm{~cm}$-es szál esetén enyhén belógatott (piros), kifeszített (kék szaggatott) és feltekert helyzetben (zöld pontozott), valamint (b), különbözö szálhosszúságok esetén: $97.5 \mathrm{~cm}$ (piros), $53.5 \mathrm{~cm}$ (kék szaggatott), $21.4 \mathrm{~cm}$ (zöld pontozott) és $10.1 \mathrm{~cm}$ (narancssárga szaggatott-pontozott) enyhén belógatott helyzetben.

Összességében elmondható, hogy a direkt módon meghatározott $D G D$-görbék pontossága a hosszabb minták esetén nagyobb, tekintve, hogy ez esetben a pontatlan gerjesztés és a késleltető elem beállítása nem okoz hibát, ami az indirekt módszer esetén viszont problémákat okozhat. Az eredmények alapján jól látszik, hogy a rövidebb szálak esetén a direkt és az indirekt módon meghatározott $D G D$-görbék pontossága összemérhetö.

\subsubsection{A fejezethez kapcsolódó tézispont}

T4. Spektrális interferometriát alkalmazva kísérletileg meghatároztam 1 méternél rövidebb HC-800-02 fotonikus optikai szálminták polarizációs módus diszperzióját indirekt és direkt megközelítést alkalmazva a 760-870 nm-es hullámhossztartományban. A polarizációs módusdiszperzió meghatározására az indirekt módszer, valamint a hosszabb szálminták esetén a direkt módszer esetén is a Fourier-transzformációs eljárást használtam, a rövidebb szálaknál pedig minimum-maximum módszert alkalmaztam a csoportkésleltetés-különbség direkt mérésekor. Eredményeimet az irodalomban található adatokkal összevetve megállapítottam, hogy nem lehetséges teljesen megegyezö struktúrájú szálakat gyártani, ezért az optikai tulajdonságokat fontos kísérletileg meghatározni. Megállapítottam, hogy a csoportkésleltetés-különbség direkt mérésén alapuló eredmények pontossága a hosszabb szálak esetén egyértelmüen kitűnik, tekintve, hogy ez független az egyes polarizációs módusok pontos gerjesztésétől és a referenciakar 
késleltető elemének pontos beállításától is. A rövidebb szálminták esetén a direkt és az indirekt módszer pontossága összemérhető [118]. 


\subsection{A kromatikus diszperzió meghatározása időben átfedő módusok esetén az ablakolt Fourier-transzformációs gerincvonal kereső algoritmus segítségével}

\subsubsection{Polarizációfüggő diszperzió kísérleti vizsgálata}

Korábban a Bragg-szál vizsgálata során pontosságát tekintve a WFR algoritmus némileg alulmúlta az FT-módszert (4.2.5 fejezet), mivel a vizsgált szál spektrumában éles rezonancia csúcsok voltak. Olyan szálak esetében, ahol a csoportkésleltetés-függvény viszont mentes ilyen ugrásoktól, használata előnyös lehet. Mivel a kiértékelés a vizsgált minta $G D$-görbéjét direkt módon szolgáltatja, a magasabb rendủ diszperzió jelenlétének detektálása például pontosabb lehet. A kiértékelés pontosságának növelése érdekében ezért az elmúlt időszakban további fejlesztések történtek. Az alábbiakban a 4.3 fejezetben ismertetett kísérleti elrendezés elemeiből felépített mérési elrendezést használva (4.36 ábra) azt vizsgálom meg, hogy ezen továbbfejlesztett WFR-módszer mennyire alkalmazható a HC-800-02 PCF polarizációfüggő diszperziójának meghatározására. A vizsgált szál hossza ez esetben $97.5 \mathrm{~cm}$ volt, az elrendezésben levő szürőket nem tüntettem fel.

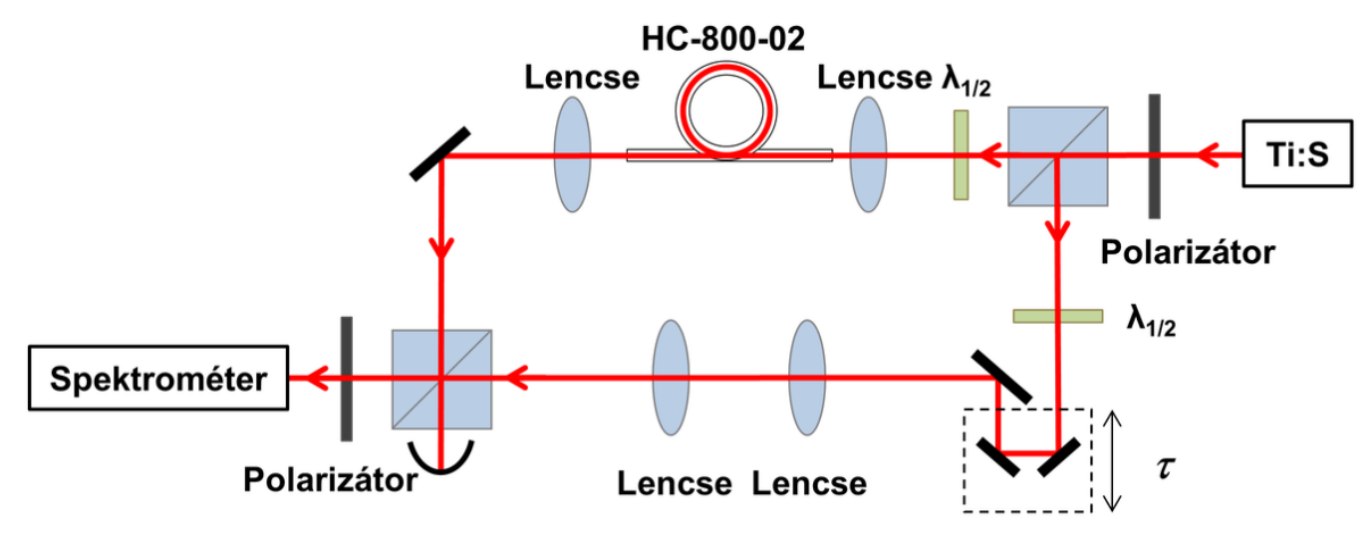

4.36 ábra Spektrálisan bontott Mach-Zehnder interferométer a HC-800-02 típusú fotonikus optikai szál diszperziójának meghatározására.

A kiértékelés legfontosabb mozzanata a megfelelő ablakfüggvény kiválasztása. Ügyelni kell arra, hogy spektrálisan elegendően szük legyen a 2.3.1.5 fejezetben leírt kritériumok miatt, de egyúttal elég széles is, ahhoz, hogy a spektrális beszükülés miatt a WFT jelben bekövetkező időbeli megnyúlást is elkerüljük. A $G D D$ és a TOD okozta időbeli kiszélesedés és csúcseltolás minimalizálásához maximum 10\%-os megnyúlást megengedve, $5 \mathrm{THz}$ szélességü ablakfüggvényt választottam. A spektrális felbontás $4 \mathrm{THz}$ 
volt, azaz az ablakfüggvények kissé átfedtek. A WFT jel előállítását követő további kiértékelés lépéseit a következőkben tekintem át.

A (2.4) és (2.9) összefüggésekböl kiindulva, a (2.14) egyenlet analógiájára a relatív csoportkésleltetésre kapjuk, hogy

$$
\frac{d \Phi}{d \omega}=G D_{m}(\Omega)+\tau
$$

A (2.34) és (4.2) összefüggésekből adódik, hogy

$$
G D_{m}(\Omega)=t_{p}(\Omega)-\tau \text {. }
$$

azaz ha a gerincvonalhoz tartozó $t_{p}$ időbeli késleltetéseket a körfrekvencia függvényében meghatározzuk, a minta csoportkésleltetése egy $\tau$ állandóval eltolva adódik. Ahogy korábban már utaltam erre, a késleltetés változtatásával a $G D$-görbe ugyan elmozdul az időtengely mentén, alakja azonban nem módosul. A HC-800-02 PCF esetén elöször a gyors, majd a lassú polarizációs módust gerjesztve, különböző késleltetések beállításával a $G D$-görbe elmozdulása a (4.37) ábrán látható. Vegyük észre, hogy bár az interferogramok felvétele páronként (a)-d), b)-e) és c)-f)) ugyanazon késleltetés mellett történt, a gyors (X) tengely esetén (4.37 a)-c) ábrasorozat) a kapott késleltetések értéke kisebb, mint a lassú (Y) tengely mentén terjedő módus gerjesztésével (4.37 d)-f) ábrasorozat) kapott jeleknél, ahogy az várható is. A kapott, 800 nm-re vonatkoztatott csoportkésleltetések értéke a gyors tengely esetén fentről lefelé haladva rendre 5.19, 3.26 és 1.91 ps, míg a lassú tengely esetében 6.46, 4.43 és 3.08 ps, azaz a két módus között megközelítőleg 1.2 ps késleltetés alakul ki a szálban való terjedés során.

A WFT jelek intenzitás-tömegközéppontjainak szoftveres megkeresésével kapott gerincvonalra egy ötödfokú polinomot illesztve a $G D$-függvényt meghatároztam (4.38 a) és b) ábra). A $D G D$-t ez esetben a referencianyaláb kitakarásával, a 4.4.2 fejezetben leírtaknak megfelelően, direkt módon, a két módus egyidejü gerjesztésekor vizsgáltam meg (4.38 c) ábra). 


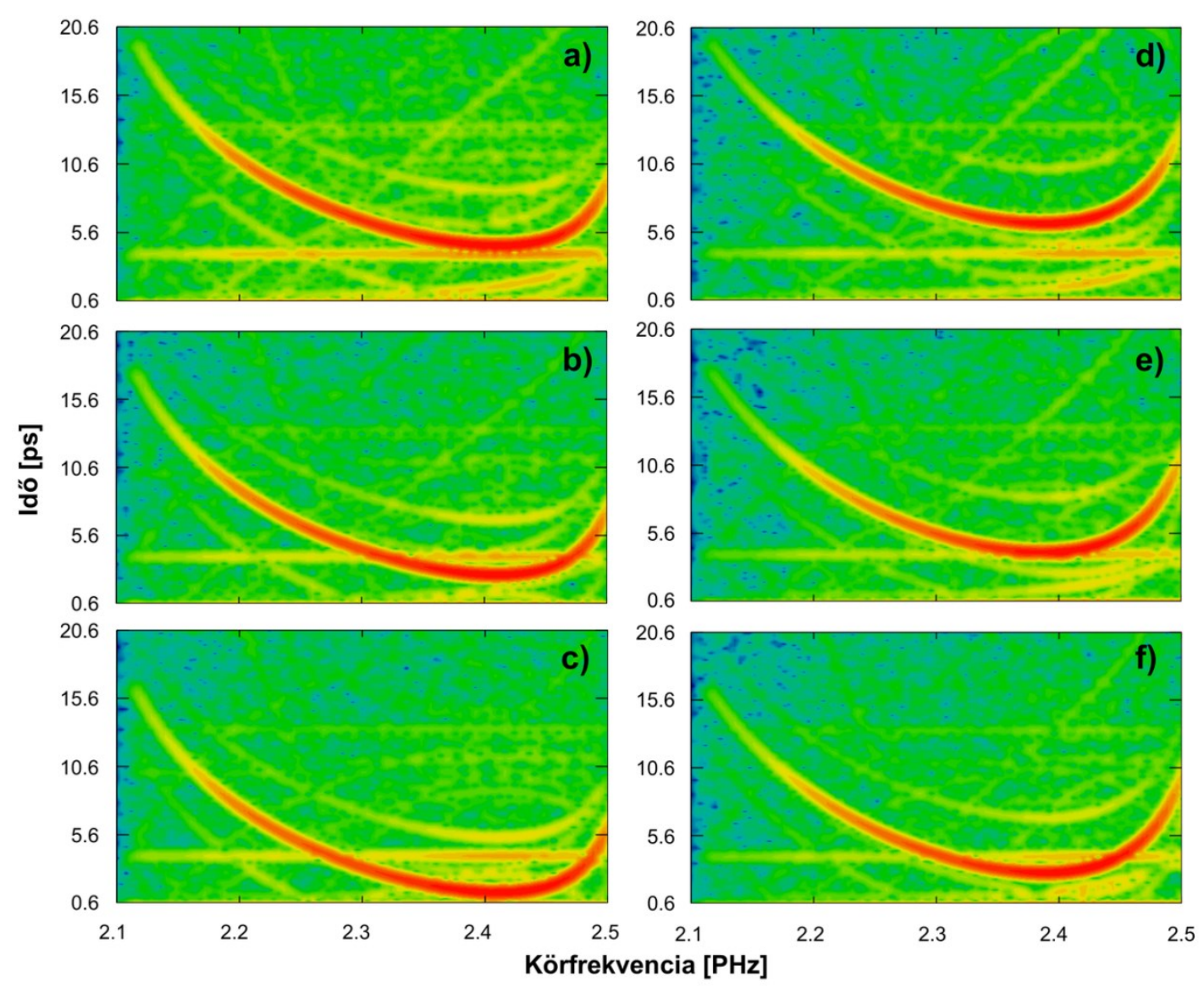

4.37 ábra (a)-(c) A gyors és (d)-(f) a lassú polarizációs módus egyenkénti gerjesztése mellett felvett interferogram ablakolt Fourier-transzformáltja különböző késleltetések esetén.
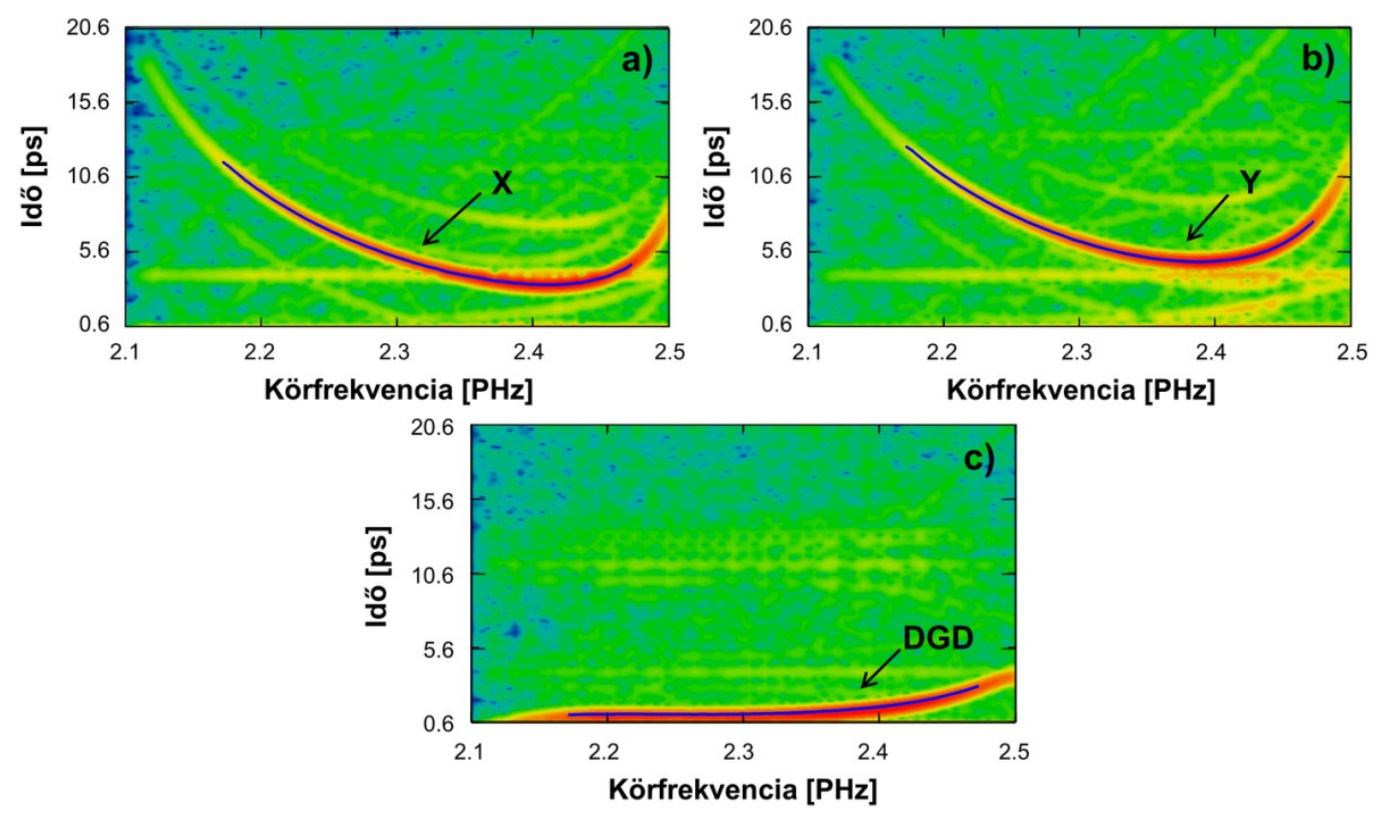

4.38 ábra (a) A gyors és (b) a lassú polarizációs tengely egyenkénti, valamint (c) a két módus egyidejü gerjesztése mellett felvett interferogram ablakolt Fourier-transzformáltja ötödfokú polinomillesztéssel.

A (4.3) összefüggés differenciálásával a $G D D$ 


$$
G D D(\Omega)=\frac{d t_{p}}{d \Omega}
$$

valamint a $D$ paraméter is könnyen számolható

$$
D(\Omega)=-\frac{2 \pi c}{\lambda^{2} L} \frac{d t_{p}}{d \Omega}
$$

Jól látszik, hogy sem a $G D D$, sem a $D$ nem függ a $\tau$ késleltetéstől, ezáltal pedig a 2.3.1.1 fejezetben bevezetett $\tau_{0}$ értékétől sem. Ettől függetlenül a megfelelő késleltetés beállítása nagy jelentőséggel bír, hiszen az interferencia csíkok sürüsége, és ezáltal láthatósága függ $\tau$-tól.
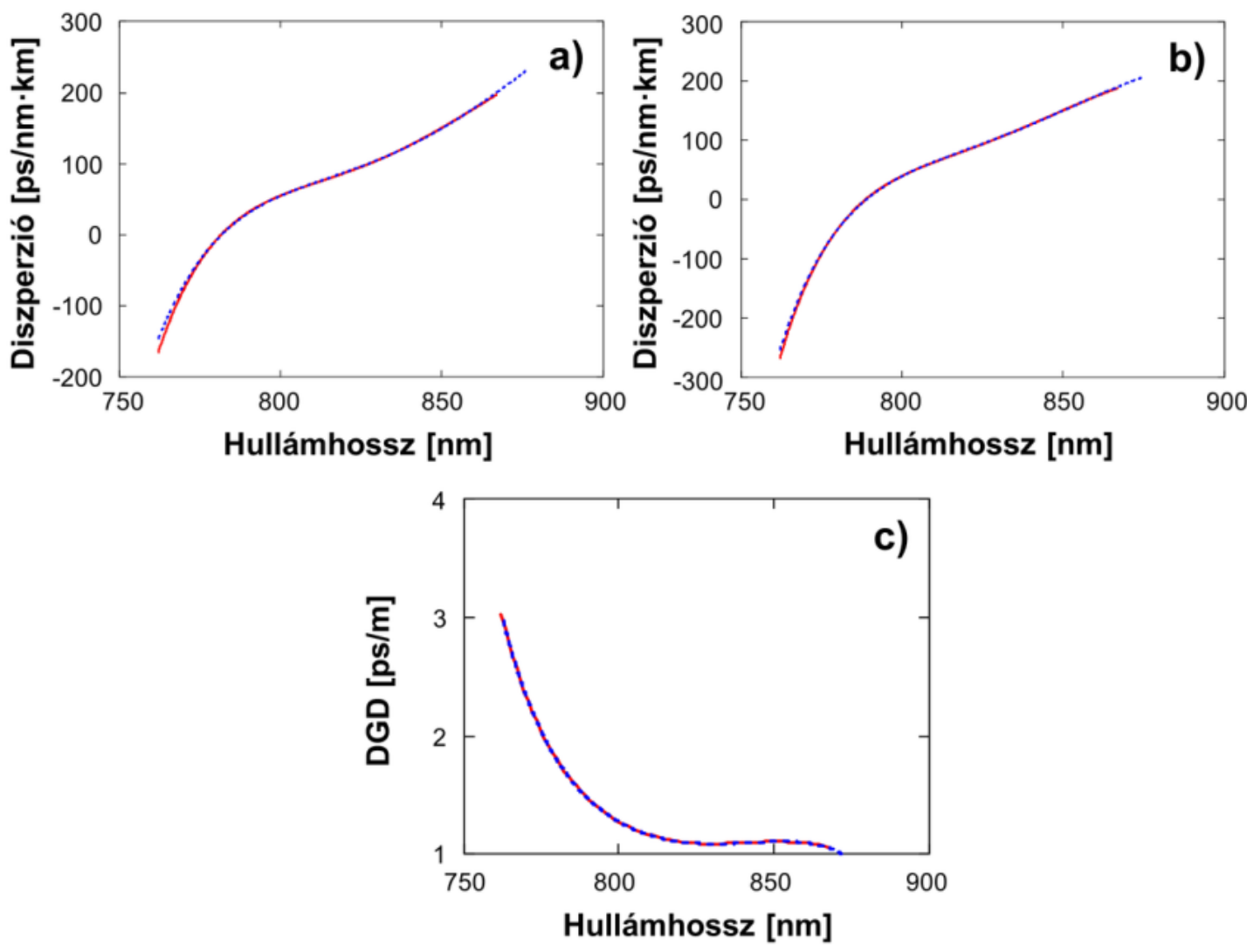

4.39 ábra A 97.5 cm hosszúságú HC-800-02 fotonikus optikai szál diszperziós görbéi (a) a gyors és (b) a lassú tengely mentén, valamint (c) a direkt módon meghatározott 1 m-es szálhosszúságra vonatkoztatott csoportkésleltetés-különbség görbe az ablakolt Fourier-transzformációs gerincvonal kereső algoritmussal (piros) és a Fourier-transzformációs módszerrel (kék szaggatott).

A WFR-módszerrel a polarizációs irányokhoz tartozó $D$-görbéket mintegy húsz interferogram kiértékelésével határoztam meg, illetve a $D G D$-t is kiszámoltam a $762 \mathrm{~nm}$ 
(2.47 PHz) és $867 \mathrm{~nm}(2.17 \mathrm{PHz})$ közötti hullámhossztartományon. A kapott eredményeket összehasonlítva a 4.3 és 4.4 fejezetekben FT kiértékeléssel adódott eredményekkel teljes egyezést figyelhetünk meg (4.39 ábra).

Jól látszik, hogy a WFR-módszer közel olyan pontos, mint az FT-módszer abban az esetben, ha a GD-függvény nem tartalmaz ugrásokat. Ennek tudatában érdemes megvizsgálni, lehetnek-e előnyei a WFR kiértékelésnek az FT-vel szemben.

\subsubsection{Időben átfedő jelek kiértékelése}

Tekintve, hogy a vizsgált HC-800-02 PCF kettőstörő, előfordulhat, hogy mindkét ortogonális polarizációs módusa gerjesztődik. Ekkor a polarizációs módusok egymással és a referencianyalábbal is interferálhatnak, feltéve, hogy annak is megfelelő a polarizációja. Ilyen esetekben az interferogram spektrális intenzitása a következőképpen írható fel:

$$
\begin{aligned}
I(\omega)= & I_{r}(\omega)+I_{t x}(\omega)+I_{t y}(\omega)+2 \sqrt{I_{r}(\omega) I_{t x}(\omega)} \cos \left(\Phi_{x}(\omega)\right)+ \\
& +2 \sqrt{I_{r}(\omega) I_{t y}(\omega)} \cos \left(\Phi_{y}(\omega)\right)+2 \sqrt{I_{t x}(\omega) I_{t y}(\omega)} \cos \left(\Phi_{x y}(\omega)\right),
\end{aligned}
$$

ahol $I_{t x}=I_{t x 0} \cos ^{2} \alpha$ és $I_{t y}=I_{t y 0} \sin ^{2} \alpha$ a tárgyimpulzusok intenzitásainak a referenciaimpulzus polarizációs síkjára vett vetületei. $\alpha$ a tárgyimpulzus $x-z$ polarizációs síkja és a referenciaimpulzus polarizációs síkja közötti szöget jelöli, $I_{t x 0}$ és $I_{t y 0}$ pedig rendre az $x-z$ és $y-z$ síkban lineárisan poláros tárgyimpulzusok bejövő intenzitásai. A (4.6) összefüggés első két tagja a referenciaimpulzus, valamint a gyors (X) és a lassú (Y) tengely mentén terjedő impulzusok interferenciáját írja le, míg a harmadik tag a két tárgyimpulzus interferenciájának következménye. A spektrális fázisok ez esetben a következőképpen írhatók fel:

$$
\begin{aligned}
& \Phi_{x}(\omega)=\varphi_{m x}(\omega)+\omega \tau, \\
& \Phi_{y}(\omega)=\varphi_{m y}(\omega)+\omega \tau, \\
& \Phi_{x y}(\omega)=\varphi_{m x}(\omega)-\varphi_{m y}(\omega) .
\end{aligned}
$$

Ekkor a (2.32) egyenletben megadott $W_{f}(\Omega, t)$ három tagból áll, így három $t_{p}$ adódik: 


$$
\begin{aligned}
& t_{p x}(\Omega)=\Phi_{x}^{\prime}(\Omega), \\
& t_{p y}(\Omega)=\Phi_{y}^{\prime}(\Omega), \\
& t_{p x y}(\Omega)=\Phi_{x y}^{\prime}(\Omega) .
\end{aligned}
$$

A két tárgyimpulzus egymással és a referenciaimpulzussal való interferenciájának eredménye három $G D$-görbe megjelenéséhez vezet:

$$
\begin{aligned}
& G D_{m x}(\Omega)=t_{p x}(\Omega)-\tau, \\
& G D_{m y}(\Omega)=t_{p y}(\Omega)-\tau, \\
& D G D(\Omega)=t_{p x y}(\Omega) .
\end{aligned}
$$

Ilyen gerjesztési beállítások mellett rögzítve, majd kiértékelve egy interferogramot, egyszerre tudunk információt szerezni a gyors és a lassú tengelyre jellemző kromatikus diszperzióról, valamint a $D G D$-ről is. A következőkben ezt a feltevést vizsgálom meg, először az FT-módszert alkalmazva.

A szál bemeneténél és a referenciakarban elhelyezett félhullámlemezt, valamint a kimenetnél lévő polarizátort az optikai szál két polarizációs irányához képest $45^{\circ}$-os szögben állítottam be. Az így kapott interferogram a 4.40 a) ábrán látható.
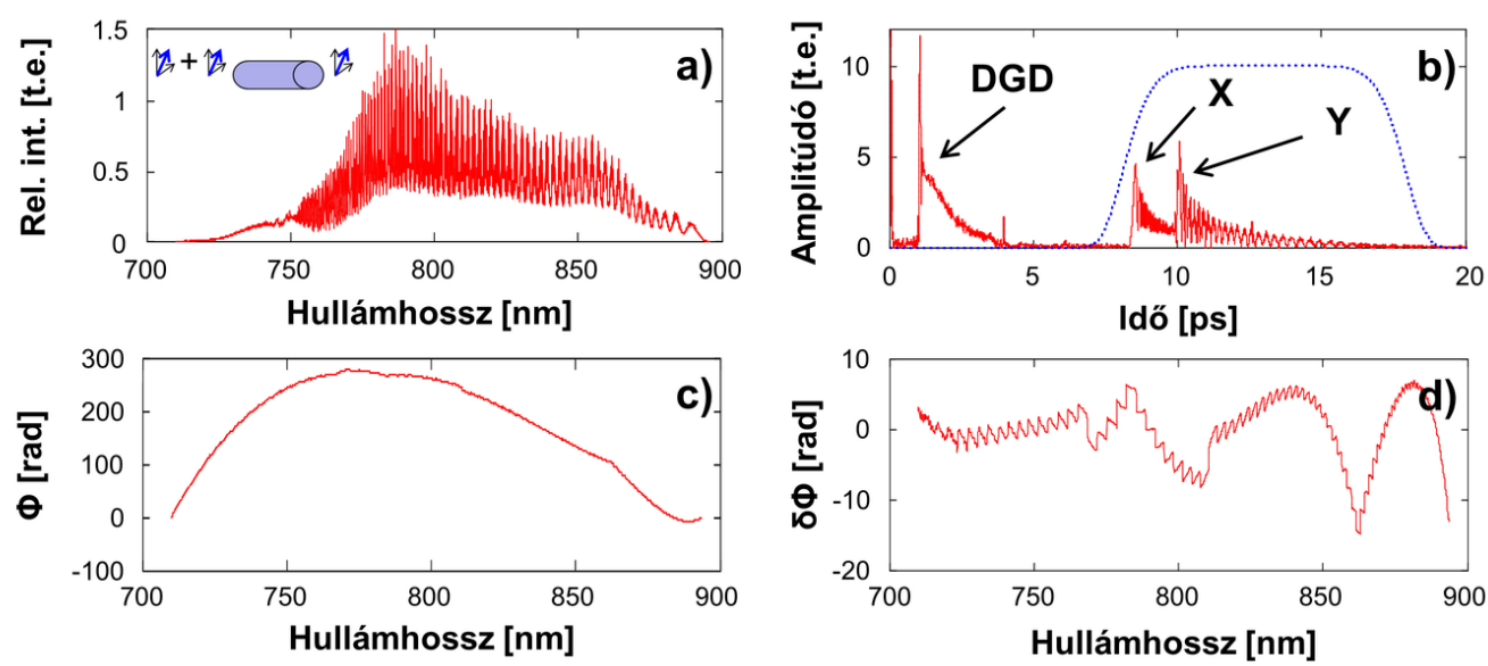

4.40 ábra (a) 97.5 cm hosszúságú HC-800-02 fotonikus optikai szál esetén felvett spektrálisan bontott interferogram a két polarizációs módus egyidejü gerjesztése mellett, (b) az interferogram Fouriertranszformáltja, (c) a Fourier-transzformációs módszerrel meghatározott spektrális fázisgörbe a lineáris tag nélkül, valamint az illesztett (d) hatodfokú polinom és a mért fázisgörbe közötti eltérés. 
FT-módszerrel kiértékelve a felvett interferogramot három jelet kapunk: az első a $D G D$, ami 1 ps-nál látható, a második és a harmadik pedig 8.7 és 10.2 ps-nál jelenik meg, melyek rendre a gyors, valamint a lassú tengely mentén terjedő impulzus referenciaimpulzussal történő interferenciájából adódnak (4.40b) ábra). Jól látszik, hogy az utóbbi két jel időben átfed, lehetetlenné téve ezáltal csupán az egyik kivágását, és így a diszperzió meghatározását a kérdéses irány mentén [99]. Az egymásra tolódott jelek kivágásával adódó spektrális fázisfüggvény pontatlansága (4.40 c) és d) ábra) jól mutatja, hogy a FT-módszer nem alkalmazható ilyen esetekben.

Ugyanezen interferogramot a WFR-módszerrel is kiértékelve azonban jól látszik, hogy a három jel időben jól elkülönül egymástól (4.41 ábra).
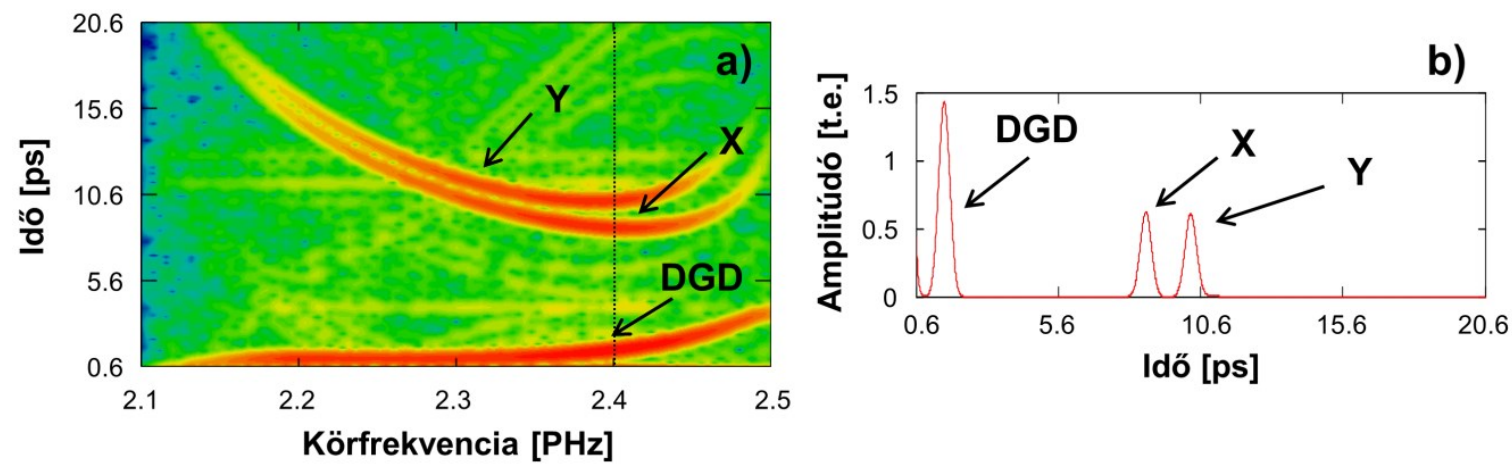

4.41 ábra A két polarizációs módus egyidejü gerjesztése mellett felvett interferogram (a) ablakolt Fouriertranszformáltja és (b) a $2.4 \mathrm{THz}$ frekvencián vett amplitúdó profilja.

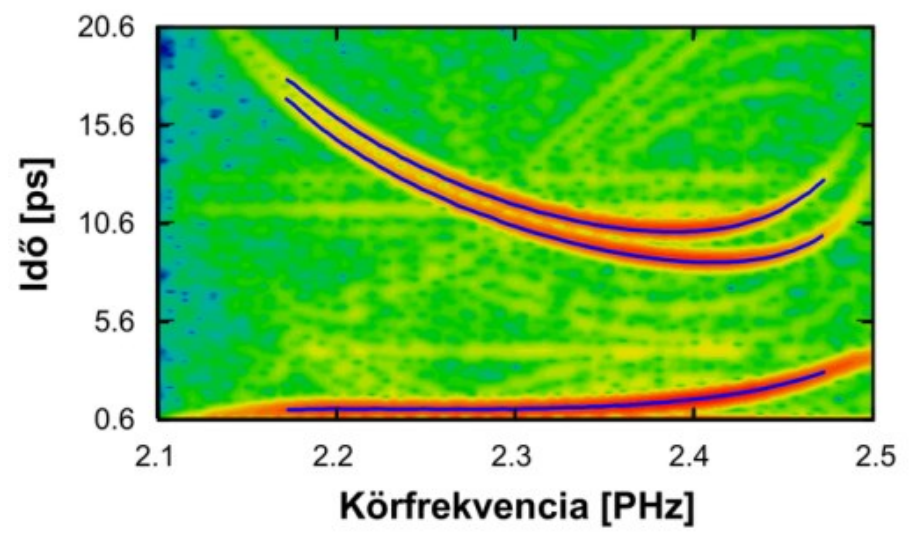

4.42 ábra A két polarizációs módus egyidejü gerjesztése mellett ablakolt Fourier-transzformációs gerincvonal kereső algoritmussal meghatározott csoportkésleltetés- és csoportkésleltetés-különbség görbék.

Látható, hogy ezt a módszert alkalmazva akár egyetlen interferogram felvétele és kiértékelése elegendő lehet a két polarizációs irány csoportkésleltetésének és a $D G D$ meghatározásához. A kapott jelekre egyenként ötödfokú polinomot illesztve (4.42 ábra), a 
két irányra jellemző $D$ - és $D G D$-görbék a korábbi fejezetekben leírt módon meghatározhatók (4.43 ábra). Érdemes azonban megvizsgálni, hogy az így meghatározható görbék mennyire pontosak. Ehhez a 4.43 ábrán a korábbi, a módusok egyenkénti gerjesztése mellett kapott $D$ - és $D G D$-görbéket is ábrázoltam (4.39 és 4.43 ábrákon pirossal jelölve). Látszik, hogy a görbék a két módus külön-külön vagy egyidejü gerjesztése mellett vonalvastagságon belül szinte tökéletesen megegyeznek, igazolva ezzel a WFR-módszer pontosságát ilyen esetekben is.
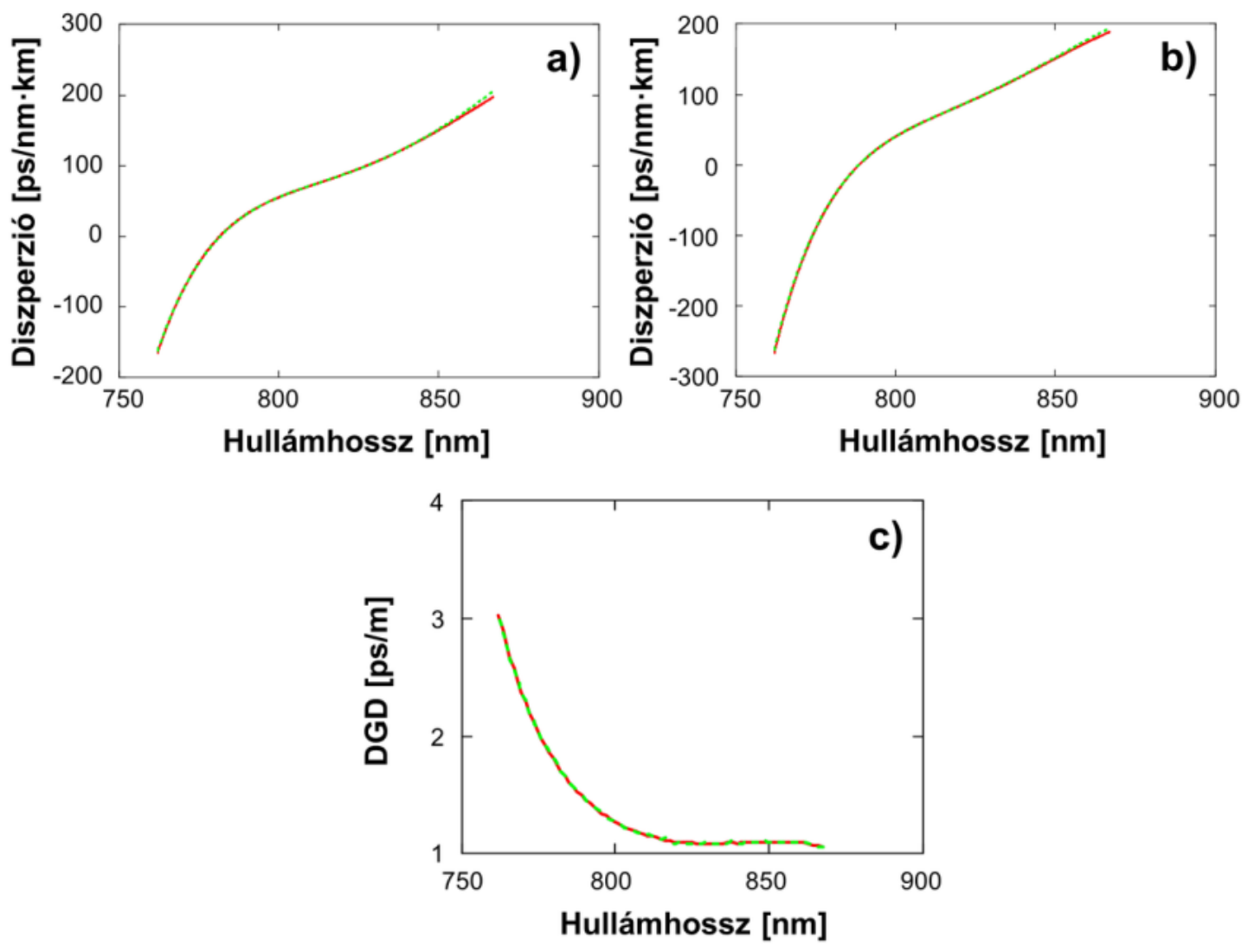

4.43 ábra A 97.5 cm hosszúságú HC-800-02 fotonikus optikai diszperziós görbéi (a) a gyors és (b) a lassú tengely mentén, valamint (c) a direkt módon meghatározott 1 m-es szálhosszúságra vonatkoztatott csoportkésleltetés-különbség görbe ablakolt Fourier-transzformációs gerincvonal kereső algoritmussal meghatározva a két módus egyenkénti (piros) és egyidejü (zöld szaggatott) gerjesztése esetén.

Összefoglalva tehát elmondható, hogy olyan szálak esetében, ahol a csoportkésleltetés-függvény egy sima görbe, mely éles rezonanciáktól mentes, az általunk továbbfejlesztett WFR pontossága megegyezik az FT-módszerével. Valódi jelentősége azonban abban rejlik, hogy akkor is megbízható eredményre vezet, ha valamilyen okból több módus gerjesztődik a szálban melyek időben átfednek, akár a kettőstörés hatása miatt, akár magasabb rendü módusok jelenléte miatt. Fontos kiemelni, hogy mindehhez egyetlen 
interferogram felvétele is elegendő, ami jelentősen gyorsítja a kiértékelést, valamint, hogy a $D G D$ is nagy pontossággal számítható ezzel a módszerrel.

A WFR-módszer további előnye, hogy a kapott GD-görbe alakjából minden további analízis nélkül vizuálisan is következtetni lehet a magasabb rendü diszperziók dominanciájára valamint elöjelére is. A vizsgált HC-800-02 PCF GD-görbéje mindkét polarizációs módus tekintetében aszimmetrikus, konvex alakot mutat (4.1 és 4.2 ábra), ami domináns, pozitív TOD jelenlétére utal [113, 115]. A kisebb körfrekvenciák környezetében jelentkező aszimmetria negatív GDD hatásának következménye. Ezen megfigyelések összhangban vannak a korábbi, 4.3-as fejezetben leírtakkal.

\subsubsection{A fejezethez kapcsolódó tézispont}

T5. Spektrális interferometria alkalmazásával kísérletileg meghatároztam 1 méternél rövidebb HC-800-02 fotonikus optikai szálminták polarizációfüggő kromatikus diszperzióját a két polarizációs módus egyidejü, valamint egyenkénti gerjesztésével a 760$870 \mathrm{~nm}$-es hullámhossztartományban. A felvett interferogramokat egy továbbfejlesztett ablakolt Fourier-transzformációs gerincvonal kereső algoritmus segítségével értékeltem ki. Az egyidejü gerjesztés mellett egyetlen interferogram kiértékelésével kapott diszperziós és csoportkésleltetés-különbség görbéket összevetve az egyenkénti gerjesztés mellett felvett, majd az ablakolt vagy a hagyományos Fourier-transzformációs módszerrel kapott görbékkel teljes egyezést tapasztaltam. Kimutattam, hogy az ablakolt Fouriertranszformációs gerincvonal kereső algoritmus további előnye, hogy a kapott $G D$-görbe alakjából minden további analízis nélkül vizuálisan is következtetni lehet a magasabb rendủ diszperziók dominanciájára valamint előjelére is [119]. 


\section{5. ÖSSZEFOGLALÓ}

Ugyan az optikai szálgyártás jelentős fejlődésen ment keresztül az elmúlt évtizedekben, mégsem lehet garantálni, hogy az elkészült szál teljes egészében a megtervezett geometriával rendelkezzen. Ez hagyományos optikai szálaknál is problémákat okoz, azonban bonyolultabb geometriával bíró, ún. mikrostruktúrált szálak esetében még inkább kritikus, mivel ezek optikai tulajdonságaira a geometria legkisebb megváltozása is nagy hatással van. Emiatt az elkészült szál gyakran nem várt vezetési, diszperziós és kettőstörő tulajdonságokat mutat. Tekintve, hogy ezen tulajdonságok nagyban befolyásolják a szálak alkalmazhatóságát, minél pontosabb méréssel történő meghatározásuk igen nagy jelentőséggel bír.

A spektrálisan bontott interferometrián alapuló méréseket széles körben alkalmazzák különböző optikai elemek, így optikai szálak diszperziójának meghatározására is. A spektrális interferometria előnye, hogy pontos, lineáris módszer, a nemlineáris módszerekhez képest aránylag olcsón megvalósítható, nem igényel hosszú (km-es) szálmintát, valamint a magasabb rendü diszperziókra is érzékeny. Mivel a felvett interferogramok kiértékelése több módszerrel is lehetséges, melyek sajátosságait azonban eddig egyetlen tanulmányban sem vetettek össze, célul tüztem ki öt gyakran alkalmazott kiértékelési eljárás összehasonlítását. Szimulációk és mérések segítségével teszteltem mely módszer milyen elönyökkel és hátrányokkal bír két, egy Bragg-típusú, valamint egy légmagos fotonikus optikai szál diszperziójának meghatározásakor.

Elsőként az állandó fázisú pont módszerének alkalmazhatóságát vizsgáltam meg harmad- és magasabb rendủ diszperziók dominanciájának kimutatására a 700-900 nm-es hullámhossztartományon. Szimulációk segítségével tanulmányoztam az állandó fázisú pontok száma, mozgása, valamint alakja és a különböző diszperziós rendek közötti kapcsolatot egészen ötödrendig. Megmutattam, hogy a legelterjedtebb üvegtípusoknál megszokott $G D D$-domináns esettől eltérően bizonyos esetekben különböző diszperziós együtthatók és azok kombinációi eredményezhetik egynél több állandó fázisú pont megjelenését. Domináns $T O D$ kettő, kombinált $G D D$ és $F O D$ három, valamint kombinált $T O D$ és $Q O D$ négy állandó fázisú pont megjelenését eredményezheti. A szimulációk segítségével megmutattam, hogy az állandó fázisú pontok számát, mozgását és alakját analizálva következtetni lehet adott magasabb rendü diszperzió dominanciájára. 
Megállapítottam, hogy az állandó fázisú pontok pozíciói nagypontossággal meghatározhatók, kivéve a tiszta $F O D$ esetében kis késleltetéseknél, amikor ugyanis az állandó fázisú pont túlságosan kiszélesedik. A szimulációk eredményét egy $30 \mathrm{~cm}$ hosszúságú Bragg-típusú mikrostruktúrált optikai szálon, valamint egy változtatható diszperzióval rendelkező prizmapáron végzett mérésekkel vetettem össze. Ehhez szélessávú fényforrásokkal kivilágított Mach-Zehnder és Michelson-interferométert építettem, detektorként a szál esetében egy nagyobb, a prizmapár esetében pedig egy kisebb felbontású spektrométert használtam. A diszperziós együtthatók állandó fázisú pont módszerével történő meghatározása után megállapítottam, hogy a Bragg-szállal felvett interferogramokon megjelenő két állandó fázisú pont valóban a domináns TOD következménye, ahogyan azt a szimulációknál is tapasztaltam. Ezzel szemben a prizmapár esetében bizonyos pozíciókban megjelenő két állandó fázisú pont kialakulását a kombinált $G D D$ és FOD okozta. Habár a szimulációk eredményéből kiindulva itt is TODdominanciájára számítottam, a látszólagos ellentmondást azzal magyarázható, hogy az általam vizsgált spektrális tartomány a szükségesnél kisebb volt, így nem tudta lekövetni az állandó fázisú pontok teljes mozgását. Az eredmények alapján megállapítottam, hogy teljes bizonyossággal csak a koefficiensek méréssel történő meghatározásával mondható meg, hogy melyik diszperziós tag a domináns.

A továbbiakban az állandó fázisú pont és további négy módszert hasonlítottam össze a korábban is vizsgált, megrendelésre készült $37 \mathrm{~cm}$-es Bragg-szál magasabb rendü diszperziójának meghatározására a 740-840 nm-es hullámhossztartományon. A mérések ismételten spektrális interferometrián alapultak, melyek során egy Mach-Zehnder interferométert építettem, tárgykarjába helyezve egy tömörmagú Bragg-típusú optikai szálat, detektorként egy nagy felbontású spektrométert, fényforrásként pedig egy Ti:S oszcillátort használtam. Megmutattam, hogy a vizsgált mikrostruktúrált optikai szál másodrendű diszperziója jelentősen kisebb a hagyományos optikai szálak esetén megszokott értékekhez viszonyítva. Ezen szál speciális tulajdonsága, mely a hullámvezető diszperzió és a tiltott sávban megjelenő szivárgó módusok együttes hatásának következménye, hogy a hagyományos optikai szálakkal ellentétben jelentős magasabb rendủ diszperzióval rendelkezik. Megállapítottam, hogy a Fourier-transzformáción alapuló kiértékelési eljárás szolgáltatta a legnagyobb pontossággal a diszperziós együtthatókat egészen ötödrendig. A fázismodulált koszinusz-függvény illesztésén alapuló módszer szintén érzékenynek bizonyult a magasabb rendű diszperziók szempontjából, míg az 
állandó fázisú pont és a minimum-maximum módszerek nem bizonyultak kellőképpen érzékenynek a magasabb rendek jelenlétére. Hasonlóan, az ablakolt Fouriertranszformáción alapuló kiértékelés pontossága sem érte el a hagyományos Fouriertranszformációs módszerét, azonban ez utóbbiak közül mindkét eljárás alkalmasnak bizonyult a szál spektrumában megjelenő abszorpciós völgyek okozta fázisugrások pontos kimutatására.

A későbbiekben egy 1 méter hosszúságú HC-800-02 légmagos fotonikus optikai szál diszperzióját vizsgáltam meg 760-870 nm-es hullámhossztartományban. A kísérleti elrendezés ez esetben egy Mach-Zehnder interferométerből, egy Ti:S oszcillátorból, valamint egy nagy felbontású spektrométerből állt. Tekintve, hogy a szál kettőstörő, a diszperzió polarizációfüggését is tanulmányoztam. A mérések kiértékeléséhez a Fouriertranszformációs módszert használtam. A diszperziós koefficienseket hatodrendig határoztam meg. Megfigyeltem, hogy ellentétben hagyományos ömlesztett kvarc-alapú egymódusú szálakkal, a vizsgált szál mindkét polarizációs irányában mért $G D D$ negatív, és abszolút értékben is kisebb, mint hasonló hosszúságú hagyományos szálak esetén várható. Megállapítottam, hogy a többi magasabb rendü tag mind pozitív előjelü, és hogy a TOD a domináns tag. Kimutattam, hogy a szál két polarizációs irányához tartozó diszperziós görbék különböznek: a kisebb hullámhosszak tartományában a gyors tengelyhez tartozó görbe esetenként $70 \%$, a lassú tengely mentén terjedő módus gerjesztésével adódó viszont jelentősebb, akár 198\%-os eltérést is mutatott a gyártó által megadott adatokból számolt görbétől. Tekintve, hogy a szálakat alkalmazás közben gyakran feltekerik, vagy meghajlítják, aminek következtében a diszperziós és kettőstörő tulajdonságok megváltozhatnak, méréseket végeztem különböző módon elhelyezett mintákon is. A diszperzió additivitását, valamint ezáltal a szál geometriájának egyenletességét különböző hosszúságú $(10 \mathrm{~cm}-1 \mathrm{~m})$ minták segítségével vizsgáltam meg. Kimutattam, hogy a szál diszperziója mindkét polarizációs irány esetén függetlennek tekinthető a szál pozíciójától és annak hosszától is.

Az előzőekben alkalmazott kísérleti elrendezést használva megmértem a HC-80002 fotonikus optikai szál polarizációs módus diszperzióját is indirekt és direkt megközelítést alkalmazva. Az indirekt módszert esetében a csoportkésleltetés-különbséget az egyes polarizációs irányokban külön-külön kimért, azonos késleltetéshez tartozó, Fourier-transzformációs módszerrel meghatározott GD-görbék egymásból történő 
kivonásával kaptam meg. Mindkét polarizációs módus azonos idejű és mértékü gerjesztésével kapott interferogramot a hosszabb $(50-100 \mathrm{~cm})$ szálminták esetén Fouriertranszformációs, a rövidebb $(10-20 \mathrm{~cm})$ szálaknál pedig minimum-maximum módszert alkalmazva a csoportkésleltetés-különbséget direkt módon mértem meg. Méréseim és korábbi irodalmi adatok összevetése azt mutatta, hogy az általam vizsgált HC-800-02 szál esetében a két módus együttes gerjesztésével kapott interferogramon az állandó fázisú pont más hullámhossznál jelent meg, mint az említett korábbi tanulmányban. Tekintve, hogy az állandó fázisú pont azonos geometriájú szálak esetében szálhossztól függetlenül ugyanott kellene, hogy megjelenjen, megfigyelésem bizonyítja, hogy nem lehetséges teljesen megegyező struktúrájú szálakat gyártani, ezért a modellezéssel kialakított geometriát és optikai tulajdonságokat nem mindig sikerül reprodukálni. Megállapítottam, hogy a csoportkésleltetés-különbség direkt mérésén alapuló eredmények pontossága a hosszabb szálak esetén egyértelműen kitünik, tekintve, hogy ez független az egyes polarizációs módusok pontos gerjesztésétől és a referenciakar késleltető elemének pontos beállításától is. A rövidebb (20 cm körüli) szálminták esetén a direkt és az indirekt módszer pontossága hasonló.

Végezetül kísérletileg meghatároztam a HC-800-02 fotonikus optikai szál polarizációfüggő kromatikus diszperzióját a két polarizációs módus egyidejű, valamint egyenkénti gerjesztésével a 760-870 nm-es hullámhossztartományban, az ablakolt Fouriertranszformációs gerincvonal kereső algoritmus segítségével. Megmutattam, hogy a szál gyors és a lassú tengelye mentén mérhető diszperzió, valamint a polarizációs módusdiszperzió nagypontosságú meghatározásához a két polarizációs módus egyidejü gerjesztése és ezek referenciaimpulzussal történő interferenciája esetén; ilyen feltételek mellett elegendő egyetlen interferogram ablakolt Fourier-transzformációs gerincvonal kereső algoritmussal történő kiértékelése. A kapott diszperziós- és csoportkésleltetéskülönbség görbéket összevetve az egyenkénti gerjesztés mellett felvett, majd az ablakolt vagy a hagyományos Fourier-transzformációs módszerrel kapott görbékkel teljes egyezést tapasztaltam. Kimutattam, hogy a ablakolt Fourier-transzformációs gerincvonal kereső algoritmus előnye a többi módszerrel szemben, hogy a mérésből a $G D$-görbét adja meg, melynek alakjából minden további analízis nélkül vizuálisan is következtetni lehet a magasabb rendü diszperziók dominanciájára valamint előjelére is. 


\section{SUMMARY}

Although the drawing process of optical fibers has become quite sophisticated and precise over the course of the last decade, it cannot be guaranteed that the manufactured fiber will possess the designed geometry. This is an obstacle even for traditional fibers but it is even more critical for fibers with complex geometries, such as microstructured fibers, since the optical properties of these fibers are greatly affected by the slightest changes in their geometry. As a result, the fabricated fiber will have different guiding, dispersion and birefringent characteristics than intended. Considering that these properties have large influence on the applicability of the fibers, characterizing them precisely using measurements is of great importance.

Measurements relying on spectrally resolved interferometry are widely used for dispersion characterization of different optical elements and fibers as well. Besides its remarkable precision, the spectrally resolved interferometry technique has numerous advantages: it is linear, therefore less expensive than the nonlinear methods, does not require a long $(\mathrm{km})$ fiber sample and it is sensitive to the presence of higher order dispersion. The evaluation of the recorded spectral interferograms can be done in several ways, however, a study, comparing their precision is lacking. Accordingly, one of my objectives was to compare five frequently used evaluation techniques. I tested the methods to highlight their benefits and drawbacks in the dispersion retrieval of a Bragg-type and a hollow-core photonic crystal fiber using simulations and measurements.

First of all, I tested the applicability of the stationary phase point method in third and higher order dispersion monitoring in the wavelength range between 700 and $900 \mathrm{~nm}$. The connection between the number, movement and shape of the stationary phase points and given dispersion terms up to the fifth order was investigated by the means of simulations. It was demonstrated that contrary to the case of dominant GDD seen in traditional glasses, dispersion of different orders and their combination can result in the appearance of more than one stationary phase points on the interferograms. Dominant TOD produces two, combined GDD and FOD three, joined TOD and $Q O D$ four stationary phase points. It was shown that by analyzing the number, movement and shape of the stationary phase points it is possible to predict which dispersion order is dominant in the spectral phase of the tested element. I concluded, that the positions of the stationary phase points 
can be determined with high precision, apart from the case of pure $F O D$, when the stationary phase point becomes too broad at low time delays. The results of the simulations were compared with measurements performed on a 30-cm-long Bragg-type microstructured fiber and a prism pair having adjustable dispersion. The experimental setup comprised a broadband light source and a Mach-Zehnder or a Michelson interferometer. A high resolution spectrometer was employed in the case of the fiber, and a lower resolution type for the prism pair. After the retrieval of the dispersion coefficients with the stationary phase point method I concluded that the appearance of the two stationary phase points on the interferograms obtained with the Bragg-fiber is a consequence of the dominant $T O D$, as predicted by the simulations. The presence of the two stationary phase points in some prism positions in the case of the prism pair, on the other hand, is the result of the combined GDD and FOD. The apparent contradiction with the results of the simulations, which suggest $T O D$-dominance from the two stationary phase points, can be interpreted as a consequence of the relatively short spectral range analyzed during the measurements. In this case the complete movement of the stationary phase points was not monitored. Based on these results I concluded that the retrival of the coefficients with measurements is crucial in order to resolve any ambiguities in deciding which dispersion term is dominant.

I tested the performance of the stationary phase point and four other methods in higher order dispersion retrieval in the wavelength range between 740 and $840 \mathrm{~nm}$ using a 37-cm-long Bragg-fiber sample. The measurements were carried out using a MachZehnder interferometer illuminated by a Ti:S oscillator. The fiber was placed in the sample arm of the interferometer and a high resolution spectrometer was used to analyze the interferograms. It was shown that $G D D$ of the tested microstructured fiber was significantly lower than the usual values seen in the case of conventional optical fibers. The special feature of this fiber is the considerable effect of higher order dispersion as a consequence of the joint effect of the waveguide dispersion and the leaking modes appearing in the photonic band gap. I concluded that the Fourier-transform evaluation method provided the dispersion coefficients with the highest accuracy up to the fifth order. The cosine function fit method was also precise regarding higher order dispersion retrieval, while the stationary phase point and the minima-maxima techniques were found insensitive to the presence of higher orders. The precision of the windowed Fourier-transform evaluation method was well below that of the conventional Fourier-method, however, only 
these two techniques were capable to detect the phase jumps caused by the absorption valleys appearing in the spectrum of the fiber.

Further on, the dispersion properties of a meter-long hollow-core photonic crystal fiber, namely the HC-800-02, was investigated in the wavelength range between 760 and $870 \mathrm{~nm}$. The experimental setup consisted of a Mach-Zehnder interferometer, a Ti:S oscillator and a high resolution spectrometer. Since the fiber was birefringent, I studied the polarization-dependence of the dispersion as well. The spectrally resolved interferograms were evaluated using the Fourier-transform method and the dispersion was retrieved up to the sixth order. It was shown that the measured $G D D$ was negative and much lower in absolute value along both polarization axes than that of conventional fused silica singlemode fibers of similar length. I showed that all other higher order dispersion coefficients were positive and that the $T O D$ is the dominant term in the spectral phase of the fiber. I confirmed that the dispersion curves obtained for the two polarization axes of the fiber were different. The curves in the lower wavelength regime retrieved by excitation of the fast and the slow polarization modes differed from the one calculated using the data provided by the manufacturer about $70 \%$ and $198 \%$, respectively. Considering, that fibers are often bent or coiled during use that can affect their dispersion and birefringent properties, I also performed measurements on fiber samples placed in different positions. The scaling of the dispersion with fiber length, i.e. the uniformity of the fiber was tested using samples of various length ranging from $10 \mathrm{~cm}$ to 1 meter. I concluded that the dispersion was mostly independent on the placement and fiber length in both polarization directions.

Using the same experimental setup as previously I measured the polarization mode dispersion of the HC-800-02 photonic crystal fiber using an indirect and a direct approach. The differential group delay was determined indirectly by separately exciting the orthogonal polarization modes and subtracting their group delay curves obtained at a same delay by the Fourier-transform method. After exciting both polarization modes of the fiber simultaneously and equally the resulting interferogram was evaluated using the Fouriertransform method in the case of the longer $(50-100 \mathrm{~cm})$ samples, and the minima-maxima method in the case of the shorter $(10-20 \mathrm{~cm})$ fibers. The comparison of the results of my measurements and previously published data revealed that the stationary phase point on the interferogram obtained by this simultaneous excitation appeared at a different wavelength 
than in the study mentioned above. The fact that the stationary phase point in the case of fibers with identical geometries should appear at the same wavelength regardless of the length of the sample, confirms that it is not possible to manufacture completely identical fibers, and that the geometry and optical properties are not necessarily the same as they were modelled. It was also shown that the precision of the direct method was greater only when longer samples were measured, since that approach did not depend on the precise excitation of a given polarization mode or on the accuracy of the translator stage in the reference arm determining the group delay. In the case of shorter (around $20 \mathrm{~cm}$ ) fibers the accuracy of the direct and indirect methods was comparable.

Finally, I experimentally retrieved the polarization dependent chromatic dispersion of the HC-800-02 fiber by exciting the orthogonal polarization modes simultaneously and separately using the windowed Fourier-ridges algorithm in the wavelength range between 760 and $870 \mathrm{~nm}$. It was shown that the chromatic dispersion along both axes and the differential group dispersion could be measured directly with high accuracy employing the windowed Fourier-ridges method on a single interferogram obtained by simultaneous excitation of the orthogonally polarized modes that interfered with a reference pulse. The retrieved dispersion and differential group dispersion curves are in complete agreement with the ones I got with the windowed and the conventional Fourier-method for interferograms recorded with separate excitation of the modes. Another advantage of the windowed Fourier-ridges technique comes to light considering the fact that it determines the group-delay curve of the sample. By observing the shape of the group delay curve the sign and the dominance of higher order dispersion can also be predicted visually without further signal processing. 


\section{KöSZÖNETNYILVÁNÍTÁS}

Első sorban témavezetőmnek, Dr. Kovács Attilának szeretném megköszönni a sok éves közös munkát, támogatást és türelmet, valamint kutatásom és szakmai fejlődésem segítését egészen a mesterképzés megkezdésétől e dolgozat megírásáig.

Köszönöm Dr. Geretovszkyné Dr. Varjú Katalinnak és Dr. Szipőcs Róbertnek, hogy a közös munka során sok ötletet és szakmai segítséget kaptam tölük. Köszönettel tartozom Dr. Heszlerné Kopniczky Juditnak az elektronmikroszkópos felvételek elkészítésében nyújtott segítségét.

Szeretném megköszönni az Optikai és Kvantumelektronikai Tanszék mindenkori vezetésének, a TeWaTi kutatócsoport tagjainak, valamint a Fizikai Intézet valamennyi oktatójának és munkatársának mindazt, amit tanulmányaim és kutatásom során tanulhattam tőlük. Köszönöm továbbá Dr. Erdélyi Miklósnak és az AdOptIm kutatócsoport többi tagjának, hogy a dolgozatírás időszakában maximális támogatásukat élvezhettem.

Végül, de nem utolsó sorban hálával tartozom édesanyámnak, bátyámnak, vőlegényemnek és barátaimnak, hogy mindig mindenben számíthattam rájuk, hogy osztozhattam velük örömömben és a nehézségek idején is erőt meríthettem támogatásukból, hiszen nélkülük most nem lehetnék itt.

Doktori munkám a TÁMOP-4.2.2.A-11/1/KONV-2012-0060 (Impulzuslézerek alkalmazása az anyagtudományban és a biofotonikában), a TECH-09-A2-2009-0134 (Új szállézeres technológián alapuló szálintegrált nemlineáris mikroendoszkóp fejlesztése farmakológiai és diagnosztikai vizsgálatokra), az EFOP-3.6.2-16-2017-00005 (Ultragyors fizikai folyamatok atomokban, molekulákban, nanoszerkezetekben és biológiai rendszerekben) és az Országos Tudományos Kutatási Alapprogramok (OTKA) NN107235 azonosítószámú projektek, valamint az Apáczai Csere János Doktoranduszi Ösztöndíj (Nemzeti Kiválóság Program, TÁMOP-4.2.4.A/2-11/1-2012-0001, pályázati azonosító: A2-ACSJD-13-0712), és a Magyar Állami Eötvös Ösztöndíj (MÁEÖ2016_3, pályázat nyilvántartási szám: 74702) keretein belül elnyert pályázati források támogatták.

Végezetül a dolgozatírással töltött elmúlt pár hónap margójára:

„Absque pugna non est victoria.” 


\section{IRODALOMJEGYZÉK}

[1] J. C. Knight, T. A. Birks, P. St. J. Russell, and D. M. Atkin, „All-silica single-mode optical fiber with photonic crystal cladding," Opt. Lett. 21(19), 1547-1549 (1996).

[2] J. C. Knight, J. Broeng, T. A. Birks, and P. St. J. Russel, „Photonic Band Gap Guidance in Optical Fibers," Science 282, 1476-1478 (1998).

[3] J. Broeng, D. Mogilevstev, S. E. Barkou, and A. Bjarklev, „Photonic Crystal Fibers: A New Class of Optical Waveguides," Opt. Fiber Technol. 5, 305-330 (1999).

[4] A. Ferrando, E. Silvestre, J. J. Miret, and P. Andrés, „Nearly zero ultraflattened dispersion in photonic crystal fibers," Opt. Lett. 25(11), 790-792 (2000).

[5] T. P. White, R. C. McPhedran, C. Martijin de Sterke, N. M. Litchinister, and B. J. Eggleton, „Resonance and scattering in microstructured fibers,” Opt. Lett. 27(22), 19771979 (2002).

[6] T. Ritari, T. Niemi, H. Ludvigsen, M. Wegmuller, N. Gisin, J. R. Folkenberg, and A. Petterson, „Polarization-mode dispersion of large mode-area photonic crystal fibers," Opt. Commun. 226, 233-239 (2003).

[7] T. Ritari, H. Ludvigsen, M. Wegmuller, M. Legré, N. Gisin, J. R. Folkenberg, and M. D. Nielsen, „Experimental study of polarization properties of highly birefringent photonic crystal fibers," Opt. Express 12(24), 5931-5939 (2004).

[8] F. Luan, A. K. George, T. D. Hedley, G. J. Pearce, D. M. Bird, J. C. Knight, and P. St. J. Russel, „All-solid photonic bandgap fiber,” Opt. Lett. 29(20), 2369-2371 (2004).

[9] P. St. J. Russell, „Photonic-Crystal Fibers,” J. Lightwave Technol. 24(12), 4729-4749 (2006).

[10] Q. Fang, Z. Wang, L. Jin, J. Liu, Y. Yue, Y. Liu, G. Kai, S. Yuan, and X. Dong, „Dispersion design of all-solid photonic bandgap fiber,” J. Opt. Soc. Am. B 24(11), 28992905 (2007).

[11] Z. Várallyay, K. Saitoh, J. Fekete, K. Kakihara, M. Koshiba, and R. Szipöcs, „Reversed dispersion slope photonic bandgap fibers for broadband dispersion control in femtosecond fiber lasers," Opt. Express 16(20), 15603-15615 (2008).

[12] S. Li, Y. Li, Y. Zhao, G. Zhou, Y. Han, and L. Hou, „Correlation between the birefringence and the structural parameter in photonic crystal fiber," Opt. Laser. Technol. 40, 663-667 (2008).

[13] Z. Várallyay, K. Saitoh, Á. Szabó, and R. Szipőcs, „Photonic bandgap fibers with resonant structures for tailoring the dispersion," Opt. Express 17(14), 11869-11883 (2009).

[14] M. Park, H. E. Arabi, S. Lee, and K. Oh, „Independent control of birefringence and chromatic dispersion in a photonic crystal fiber using two hollow ring defects," Opt. Commun. 284, 4914-4919 (2011). 
[15] P. Yeh, A. Yariv, and E. Marom, „Theory of Bragg fiber,” J. Opt. Soc. Am. 68(9), 1196-1201 (1978).

[16] S. Février, R. Jamier, J.-M. Blondy, S. L. Semjonov, M. E. Likhachev, M. M. Bubnov, E. M. Dianov, V. F. Khopin, M. Y. Salganskii, and A. N. Guryanov, „Low-loss singlemode large mode area all-silica photonic bandgap fiber," Opt. Express 14(2), 562569 (2006).

[17] J. Fekete, Z. Várallyay, and R. Szipőcs, „Design of high-bandwidth one- and two dimensional photonic bandgap dielectric structures at grazing incidence of light," Appl. Opt. 47(29), 5330-5336 (2008).

[18] Y. A. Zinin, A. V. Panov, and Y. N. Kulchin, „Hollow core Bragg fiber with antiresonant intermediate layer," Proc. SPIE 10176, 101760L (2016).

[19] J. Broeng, S. E. Barkou, T. Sondergaard, and A. Bjarklev, „Analysis of air-guiding photonic bandgap fibers," Opt. Lett. 25(2), 96-98 (2000).

[20] G. Bouwmans, F. Luan, J. C. Knight, P. St. J. Russell, L. Farr, B. J. Mangan, and H. Sabert, „Properties of a hollow-core photonic bandgap fiber at $850 \mathrm{~nm}$ wavelength,” Opt. Express 11(14), 1613-1620 (2003).

[21] W. Göbel, A. Nimmerjahn, and F. Helmchen, „Distortion-free delivery of nanojoule femtosecond pulses from Ti:sapphire laser through a hollow-core photonic crystal fiber," Opt. Lett. 29(11), 1285-1287 (2004).

[22] A. A. Ishaaya, C. J. Hensley, B. Shim, S. Schrauth, K. W. Koch, and A. L. Gaeta, "Highly-efficient coupling of linearly- and radially-polarized femtosecond pulses in hollow-core photonic band-gap fibers," Opt. Express 17(21), 18630-18637 (2009).

[23] R. Bhattacharya, and S. Konar, „Extremely large birefringence and shifting of zero dispersion wavelength of photonic crystal fibers," Opt. Laser Technol. 44, 2210-2216 (2012).

[24] H. Choi, and P. T. C. So, „Improving femtosecond laser pulse delivery through a hollow core photonic crystal fiber for temporally focused two-photon endomicroscopy," Scientific Reports 4(6626), 1-7 (2014).

[25] M. Kuschnerov, B. J. Mangan, K. Gong, V. A. J. M. Sleiffer, M. Herrmann, J. W. Nicholson, J. M. Fini, L. Meng, R. S. Windeler, E. M. Monberg, A. DeSantolo, K. Mukasa, V. Mikhailov, U. Feiste, W. Zhang, and R. Yu, „Transmission of Commercial Low Latency Interfaces over Hollow-Core Fiber," J. Lightwave Technol. 34(2), 314-320 (2016).

[26] http://www.nktphotonics.com/wp-content/uploads/2015/01/HC-800.pdf

[27] S. Loranger, and R. Kashyap, „Are optical fibers really uniform? Measurement of refractive index on a centimeter scale," Opt. Lett. 42(9), 1832-1835 (2017).

[28] L. G. Cohen, „Comparison of Single-Mode Fiber Dispersion Measurement Techniques,” J. Lightwave Technol. 3(5), 958-966 (1985). 
[29] M. A. Galle, W. Mohammed, L. Qian, and P. W. E. Smith, ,Single-arm three-wave interferometer for measuring dispersion of short lengths of fiber," Opt. Express 15(25), 16896-16908 (2007).

[30] W. J. Bock, and W. Urbanczyk, „Measurement of polarization mode dispersion and modal birefringence in highly birefringent fibers by means of electronically scanned shearing-type interferometry," Appl. Opt. 32(30), 5841-5848 (1993).

[31] P. Hlubina, T. Martynkien, and W. Urbańczyk, „Measurement of birefringence dispersion and intermodal dispersion in a two-mode elliptical-core optical fibre using an interferometric method," Optik 115(3), 109-114 (2004).

[32] B. E. A. Saleh, and M. C. Teich: Fundamentals of Photonics (2nd Ed., John Wiley and Sons, 2007)

[33] P. St. J. Russell, and G. J. Pearce: Photonic Crystal Fibers in Handbook of Optics, Volume V, (3rd Ed., McGraw-Hill, 2010)

[34] F. Weise, G. Achazi, M. Pawlowska, and A. Lindinger, „Systematic variation of parametrically shaped sub-pulse sequences after transmission through a photonic crystal fiber,” Opt. Commun. 284, 3759-3771 (2011).

[35] Q-L. Zhou, X-Q. Lu, D-P. Chen, C-S. Zhu, and J-R. Qiu, „A new method of modeling cladding band structure of air-guiding photonic crystal fibers," J. Non-Cryst. Solids 354, 1201-1204 (2008).

[36] G. Statkiewicz, T. Martynkien, and W. Urbańczyk, „Measurements of birefringence and its sensitivity to hydrostatic pressure and elongation in photonic bandgap hollow core fiber with residual core ellipticity," Opt. Commun. 255, 175-183 (2005).

[37] F. Brechet, P. Roy, J. Marcou, and D. Pagnoux, „Single-Mode Propagation in Depressed-Core-Index Photonic-Bandgap Fiber Designed for Zero-Dispersion Propagation at Short Wavelengths," Electron. Lett. 36(6), 514-515 (2000).

[38] S. G. Johnson, M. Ibanescu, M. Skorobogatiy, O. Weisberg, T. D. Engeness, M. Soljacic, S. A. Jacobs, J. D. Joannopoulos, and Y. Fink, „Low-Loss Asymptotically SingleMode Propagation in Large-Core Omniguide Fibers," Opt. Express 9(13), 748-779 (2001).

[39] http://www.rp-photonics.com/waveguide_dispersion.html (Encyclopedia for Photonics and Laser Technology)

[40] I. P. Kaminov, „Polarization in optical fibers,” IEEE J. Quantum. Electron. 17(1), 1522 (1981).

[41] K. Saitoh, and M. Koshiba, „Photonic bandgap fibers with high birefringence,” IEEE Photon. Technol. Lett. 14(9), 1291-1293 (2002).

[42] X. Chen, M. J. Li, N. Venkataraman, M. Gallagher, W. Wood, A. Crowley, J. Carberry, L. Zenteno, and K. Koch, „Highly birefringent hollow-core photonic bandgap fiber," Opt. Express 12(16), 3888-3893 (2004). 
[43] P. J. Roberts, D. P. Williams, H. Sabert, B. J. Mangan, D. M. Bird, T. A. Birks, J. C. Knight, and P. St. J. Russel, „Design of low-loss and highly birefringent hollow-core photonic crystal fiber," Opt. Express 14(16), 7329-7341 (2006).

[44] P. J. Roberts, D. P. Williams, B. J. Mangan, H. Sabert, F. Couny, W. J. Wadsworth, T. A. Birks, J. C. Knight, and P. St. J. Russel, „Realizing low loss air core photonic crystal fibers by exploiting an antiresonant core surround," Opt. Express 13(20), 8277-8285 (2005).

[45] F. Poletti, N. G. R. Broderick, D. J. Richardson, and T. M. Monro, „The effect of core asymmetries on the polarization properties of hollow core photonic bandgap fibers," Opt. Express 13(22), 9115-9124 (2005).

[46] M.-J. Li, J. A. West, and K. W. Koch, „Modeling Effects of Structural Distortions on Air-Core Photonic Bandgap Fibers," J. Lightwave Technol. 25(9), 2463-2468 (2007).

[47] M. Wegmuller, M. Legré, N. Gisin, T. P. Hansen, C. Jackobsen, and J. Broeng, „Experimental investigation of the polarization properties of a hollow core photonic bandgap fiber for $1550 \mathrm{~nm}$," Opt. Express 13(5), 1457-1467 (2005).

[48] C. M. Smith, N. Venkataraman, M. T. Gallagher, D. Müller, J. A. West, N. F. Borrelli, D. C. Allan, and K. W. Koch, „Low-loss hollow-core silica/air photonic bandgap fibre,” Nature 424, 657-659 (2003).

[49] P. J. Roberts, F. Couny, H. Sabert, B. J. Mangan, D. P. Williams, L. Farr, M. W. Mason, A. Tomlinson, T. A. Birks, J. C. Knight, and P. St. J. Russel, „Ultimate low loss of hollow-core photonic crystal fibers," Opt. Express 13(1), 236-244 (2005).

[50] C. Markos, „Photonic-crystal fibre: Mapping the structure,” Nat. Photon. 9, 9-11 (2015).

[51] J-C. Diels, W. Rudolph: Ultrashort Laser Pulse Phenomena (2nd Ed., Elsevier, 2006)

[52] G. Genty, and H. Ludvigsen, „Measurement of anomalous dispersion in microstructured fibers using spectral modulation," Opt. Express 12(5), 929-934 (2004).

[53] H-T. Shang, „Chromatic dispersion measurement by white-light interferometry on metre-length single-mode optical fibres," Electron. Lett. 17(17), 603-605 (1981).

[54] J. Y. Lee, and D. Y. Kim, „Versatile chromatic dispersion measurement of a single mode fiber using spectral white light interferometry," Opt. Express 14(24), 11608-11615 (2006).

[55] Q. Ye, Ch. Xu, X. Liu, W. H. Knox, M. F. Yan, R. S. Windeler, and B. Eggleton, „Dispersion measurement of tapered air-silica microstructure fiber by white-light interferometry,” Appl. Opt. 41(22), 4467-4470 (2002).

[56] S. Diddams, and J.-C. Diels, „Dispersion measurements with white-light interferometry," J. Opt. Soc. Am. B 13(6), 1120-1129 (1996).

[57] I. H. Malitson, „Interspecimen Comparison of the Refractive Index of Fused Silica,” J. Opt. Soc. Am. 55(10), 1205-1208 (1965). 
[58] N. Gisin, J. P. von der Weid, and J. Pellaux, „Polarization mode dispersion of short and long single-mode fibers," J. Lightwave Technol. 9(7), 821-827 (1991).

[59] I. Walmsley, L. Waxer, and Christophe Dorrer, „The role of dispersion in ultrafast optics,” Rev. Sci. Instrum. 72(1), 1-29 (2001).

[60] J.-C. M. Diels, J. J. Fontaine, I. C. McMichael, and F. Simoni, „Control and measurement of ultrashort pulse shapes (in amplitude and phase) with femtosecond accuracy," Appl. Opt. 24(9), 1270-1282 (1985).

[61] T. Hirayama, and M. Sheik-Bahae, „Real-time chirp diagnostic for ultrashort laser pulses," Opt. Lett. 27(10), 860-862 (2002).

[62] A. K. Sharma, P. A. Naik, and P. D. Gupta, „Estimation of higher order chirp in ultrashort laser pulses using modified spectrum auto-interferometric correlation," Opt. Commun. 233, 431-437 (2004).

[63] B. Yellampalle, R. D. Averitt, and A. J. Taylor, „Unambiguous chirp characterization using modified-spectrum auto-inerferometric correlation and pulse spectrum," Opt. Express 14(19), 8890-8899 (2006).

[64] D. A. Bender, J. W. Nicholson, and M. Sheik-Bahae, „Ultrashort laser pulse characterization using modified spectrum auto-interferometric correlation (MOSAIC)," Opt. Express 16(16), 11782-11794 (2008).

[65] R. Trebino, K. W. DeLong, D. N. Fittinghoff, J. N. Sweetser, M. A. Krumbügel, B. A. Richman, and D. J. Kane, „Measuring ultrashort laser pulses in the time-frequency domain using frequency-resolved optical gating,” Rev. Sci. Instrum. 68(9), 3277-3295 (1997).

[66] C. Iaconis, and I. A. Walmsley, „,Spectral phase interferometry for direct electric-field reconstruction of ultrashort pulses," Opt. Lett. 23(10), 792-794 (1998).

[67] T. M. Shuman, M. E. Anderson, J. Bromage, Ch. Iaconis, L. Waxer, and I. A. Walmsley, „Real-time SPIDER: ultrashort pulse characterization at $20 \mathrm{~Hz}$,” Opt. Express 5(6), 134-143 (1999).

[68] G. Stibenz, C. Ropers, Ch. Lienau, Ch. Warmuth, A. S. Wyatt, I. A. Walmsley, and G. Steinmeyer, „Advanced methods for the characterization of few-cycle light pulses: a comparison,” Appl. Phys. B 83,511-519 (2006).

[69] W. H. Knox, „Dispersion Measurements for Femtosecond-Pulse Generation and Applications," Appl. Phys. B 58, 225-235 (1994).

[70] Kovács Attila, „Optikai elemek fázistulajdonságainak interferometrikus vizsgálata,” Ph.D. értekezés, Szegedi Tudományegyetem, Optikai és Kvantumelektronikai Tanszék, Szeged (2000).

[71] M. Tateda, N. Shibata, and S. Seikai, „Interferometric method for chromatic dispersion measurement in a single-mode optical fiber," IEEE J. Quantum Electron. 17(3), 404-407 (1981). 
[72] W. H. Knox, N. M. Pearson, K. D. Li, and C. A. Hirlimann, „Interferometric measurements of femtosecond group delay in optical components," Opt. Lett. 13(7), 574576 (1988).

[73] Z. Bor, K. Osvay, B. Rácz, and G. Szabó, „Group refractive index measurement by Michelson interferometer," Opt. Commun. 78, 109-112 (1990).

[74] M. Beck, and I. A. Walmsley, „Measurement of group delay with high temporal and spectral resolution," Opt. Lett. 15(9), 492-494 (1990).

[75] M. Beck, I. A. Walmsley, and J. D. Kafka, „Group delay measurements of optical components near 800 nm,” IEEE J. Quantum Electron. 27(8), 2074-2081 (1991).

[76] K. Naganuma, K. Mogi, and H. Yamada, „Group-delay measurement using the Fourier transform of an interferometric cross correlation generated by white light," Opt. Lett. 15(7), 393-395 (1990).

[77] A. Gosteva, M. Haiml, R. Paschotta, and U. Keller, „Noise-related resolution limit of dispersion measurements with white-light interferometers," J. Opt. Soc. Am. B 22(9), 1868-1874 (2005).

[78] A. P. Kovács, K. Osvay, G. Kurdi, M. Görbe, J. Klebniczki, and Zs. Bor, „Dispersion control of a pulse stretcher-compressor system with two dimensional spectral interferometry," Appl. Phys. B 80, 165-170 (2005).

[79] P. Bowlan, P. Gabolde, A. Shreenath, K. McGresham, and Rick Trebino, „Crossedbeam spectral interferometry: a simple, high-spectral-resolution method for completely characterizing complex ultrashort pulses in real time," Opt. Express 14(24), 11893-11900 (2006).

[80] Börzsönyi Ádám, „Spektrálisan és térben bontott interferometria vizsgálata és alkalmazásai," Ph.D. értekezés, Szegedi Tudományegyetem, Optikai és Kvantumelektronikai Tanszék, Szeged (2012).

[81] A. Borzsonyi, A. P. Kovacs, and K. Osvay, „What We Can Learn about Ultrashort Pulses by Linear Optical Methods,” Appl. Sci. 3, 515-544 (2013).

[82] C. Sáinz, P. Jourdain, R. Escalona and J. Calatroni, „Real-time interferometric measurements of dispersion curves," Opt. Commun. 111, 632-641 (1994).

[83] R. Szipöcs, and A. P. Kovács, „Dispersion measurement on crystals for ultrashort pulse generation with use of interference in the frequency domain," in Conference on Lasers and Electro-Optics, D. Killinger, G. Valley, C. Chang-Hasnain, and W. Knox, eds., Vol. 11 of OSA Technical Digest (Optical Society of America, Washington D.C., 1997), paper CTuP32.

[84] L. M. Simohamed, and F. Reynaud, „Characterisation of the dispersion evolution versus stretching in a large stroke optical fibre delay line," Opt. Commun. 159, 118-128 (1999). 
[85] P. Hlubina, D. Ciprian, and L. Knyblová, „Direct measurement of dispersion of the group refractive indices of quartz crystal by white-light spectral interferometry," Opt. Commun. 269, 8-13 (2007).

[86] P. Hlubina, and J. Olszewski, „Phase retrieval from spectral interferograms including the stationary-phase point," Opt. Commun. 285, 4733-4738 (2012).

[87] F. Koch, S. V. Chernikov, and J. R. Taylor, „Dispersion measurement in optical fibres over the entire spectral range from $1.1 \mu \mathrm{m}$ to $1.7 \mu \mathrm{m}$," Opt. Commun. 175, 209-213 (2000).

[88] P. Hlubina, M. Szpulak, D. Ciprian, T. Martynkien, and W. Urbanczyk, „Measurement of the group dispersion of the fundamental mode of holey fiber by whitelight spectral interferometry," Opt. Express 15(18), 11073-11081 (2007).

[89] P. Hlubina, „White-light spectral interferometry to measure intermodal dispersion in two-mode ellipitical-core optical fibres," Opt. Commun. 218, 283-289 (2003).

[90] P. Tournois, „New diffraction grating pair with very linear dispersion for laser pulse compression," Electron. Lett. 29(16), 1414-1415 (1993).

[91] J. Jasapara, T. H. Her, R. Bise, R. Windeler, and D. J. DiGiovanni, „Group-velocity dispersion measurements in a photonic bandgap fiber," J. Opt. Soc. Am. B 20(8), 16111615 (2003).

[92] L. Zong, F. Luo, S. Cui, and X. Cao, „Rapid and accurate chromatic dispersion measurement of fiber using asymmetric Sagnac interferometer," Opt. Lett. 36(5), 660-662 (2011).

[93] P. Hlubina, M. Kadulová, and D. Ciprian, „Spectral interferometry-based chromatic dispersion measurement of fibre including the zero-dispersion wavelength," J. Europ. Opt. Soc. Rap. Public 7, 12017-1-5 (2012).

[94] T. M. Kardas, and C. Radzewicz, „Broadband near-infrared fibers dispersion measurement using white light interferometry," Opt. Commun. 282, 4361-4365 (2009).

[95] M. Takeda, H. Ina, and S. Kobayashi, „Fourier-transform method of fringe-pattern analysis for computer-based topography and interferometry," J. Opt. Soc. Am. 72(1), 156160 (1982).

[96] L. Lepetit, G. Chériaux, and M. Joffre, „Linear techniques of phase measurement by femtosecond spectral interferometry for applications in spectroscopy," J. Opt. Soc. Am. B 12(12), 2467-2474 (1995).

[97] Ch. Dorrer, „Influence of the calibration of the detector on spectral interferometry,” J. Opt. Soc. Am. B 16(7), 1160-1168 (1999).

[98] Ch. Dorrer, N. Belabas, J. P. Likforman and M. Joffre, „Spectral resolution and sampling issues in Fourier-transform spectral interferometry," J. Opt. Soc. Am. B 17(10), 1795-1802 (2000). 
[99] D. K. Gifford, B. J. Soller, M. S. Wolfe, and M. E. Frogatt, „Optical vector network analyzer for single-scan measurements of loss, group delay, and polarization mode dispersion," Appl. Opt. 44(34), 7282-7286 (2005).

[100] S. K. Debnath, M. P. Kothiyal, and S.-W. Kim, „Evaluation of spectral phase in spectrally resolved white-light interferometry: Comparative study of single-frame techniques," Opt. Laser Eng. 47, 1125-1130 (2009).

[101] N. K. Berger, B. Levit, and B. Fischer, „Measurement of fiber chromatic dispersion using spectral interferometry with modulation of dispersed laser pulses," Opt. Commun. 283, 3953-3956 (2010).

[102] L. Huang, Q. Kemao, B. Pan, and A. K. Asundi, „Comparison of Fourier transform, windowed Fourier transform, and wavelet transform methods for phase extraction from a single fringe pattern in fringe projection profilometry," Opt. Laser Eng. 48, 141-148 (2010).

[103] Q. Kemao, „Windowed Fourier transform for fringe pattern analysis,” Appl. Opt. 43(13), 2695-2702 (2004).

[104] Q. Kemao, „On window size selection in the windowed Fourier ridges algorithm,” Opt. Laser Eng. 45, 1186-1192 (2007).

[105] Q. Kemao, „On window size selection in the windowed Fourier ridges algorithm: Addendum," Opt. Laser Eng. 45, 1193-1195 (2007).

[106] Q. Kemao, „Applications of windowed Fourier fringe analysis in optical measurement: A review," Opt. Laser Eng. 66, 67-73 (2015).

[107] P. Hlubina, J. Luňáček, D. Ciprian, and R. Chlebus, „Windowed Fourier transform applied in the wavelength domain to process the spectral interference signals," Opt. Commun. 281, 2349-2354 (2008).

[108] P. Hlubina, and D. Ciprian, „Absolute phase birefringence dispersion in polarizationmaintaining fiber or birefringent crystal retrieved from a channeled spectrum," Opt. Lett. 35(10) 1566-1568 (2010).

[109] P. Hlubina, J. Luňáček, and D. Ciprian, „Spectral interferometry and reflectometry used for characterization of a multilayer mirror," Opt. Lett. 34(10), 1564-1566 (2009).

[110] Z. Luo, S. Zhang, W. Shen, C. Xia, Q. Ma, X. Liu, and Y. Zhang, „Group delay dispersion measurement of a dispersive mirror by spectral interferometry: comparison of different signal processing algorithms," Appl. Opt. 50(9), 239-245 (2011).

[111] J. W. Nicholson, L. Meng, J. M. Fini, R. S. Windeler, A. DeSantolo, E. Monberg, F. DiMarcello, Y. Dulashko, M. Hassan, and R. Ortiz, ,Measuring higher-order modes in a low-loss, hollow-core, photonic-bandgap fiber," Opt. Express 20(18), 20494-20505 (2012).

[112] J. Bethge, C. Grebing, and G. Steinmeyer, „A fast Gabor wavelet transform for highprecision phase retrieval in spectral interferometry," Opt. Express 15(22), 14313-14321 (2007). 
[113] K. Mecseki, and A. P. Kovács, „Monitoring of Residual Higher-Order Dispersion of Pulse Compression by Spectral Interferometry,” Proc. AIP 1228, 251-256 (2010).

[114] S. Kane, and J. Squier, „Grism-pair stretcher-compressor system for simultaneous second- and third-order dispersion compensation in chirped-pulse amplification," J. Opt. Soc. Am. B 14(3) 661-665 (1997).

[115] T. Grósz, A. P. Kovács, K. Mecseki, L. Gulyás, and R. Szipőcs, „Monitoring the dominance of higher-order chromatic dispersion with spectral interferometry using the stationary phase point method," Opt. Commun. 338, 292-299 (2015).

[116] T. Grósz, A. P. Kovács, M. Kiss, and R. Szipőcs, „Measurement of higher order chromatic dispersion in a photonic bandgap fiber: comparative study of spectral interferometric methods," Appl. Opt. 53(9), 1929-1937 (2014).

[117] A. Papp, and H. Harms, „Polarization optics of liquid-core optical fibers,” Appl. Opt. 16(5), 1315-1319 (1977).

[118] T. Grósz, A. P. Kovács and K. Varjú, „Chromatic Dispersion Measurement along Both Polarization Directions of a Birefringent Hollow-core Photonic Crystal Fiber Using Spectral Interferometry,” Appl. Opt. 56(19), 5369-5376 (2017).

[119] T. Grósz, M. Horváth, and A. P. Kovács, „Complete dispersion characterization of optical fibers from a single interferogram using the windowed Fourier ridges algorithm," Opt. Express, megjelenés alatt (2017). 